\begin{tabular}{|c|c|}
\hline W 43 ENGINEERING DATA TRANSMITTAL & Pag= 1 of $\frac{1}{1}$ \\
\hline
\end{tabular}

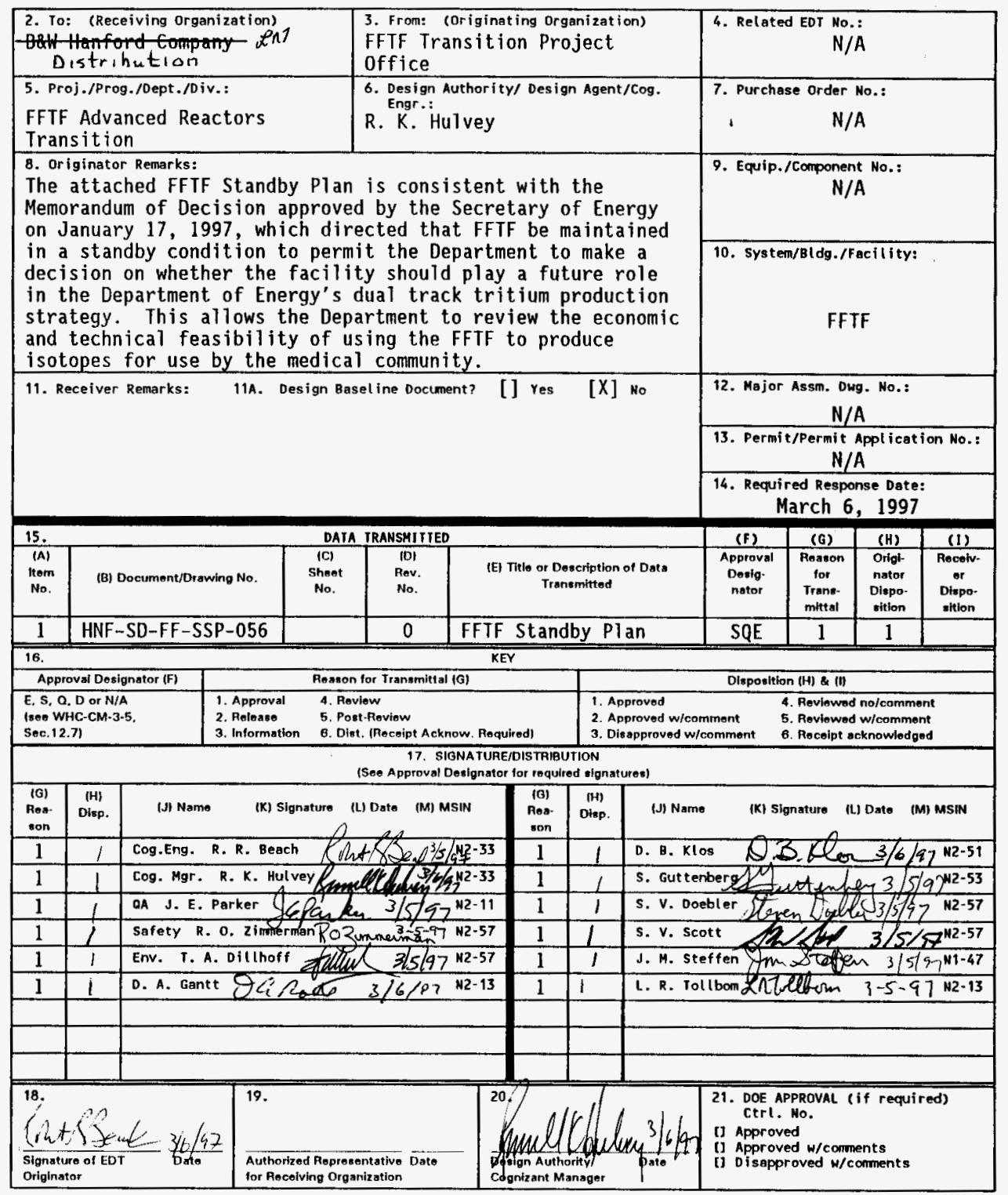

BD - 7400-172-2(05/96) GEF097 


\title{
Fast Flux Test Facility Standby Plan
}

\author{
R. K. Hulvey
}

B\&W Hanford Company, Richland, WA 99352

U.S. Department of Energy Contract DE-AC06-96RL13200

EDT/ECN: 619590

Org Code: 18300

B\&R Code: EX7005000
UC: 500

Charge Code: B171A

Tota1 Pages: 120

Key Words: Fast Flux Test Facility, Standby Plan, Sodium, Fuel Offload, Fue] Washing

Abstract: The FFTF Standby Plan, Revision 0 , provides changes to the major elements and project baselines to maintain the FFTF plant in a standby condition and to continue washing sodium from irradiated reactor fuel. The PIan is consistent with the Memorandum of Decision approved by the Secretary of Energy on January 17, 1997, which directed that FFTF be maintained in a standby condition to permit the Department to make a decision on whether the facility should play a future role in the Department of Energy's dual track tritium production strategy. This decision would be made in parallel with the intended December 1998 decision on the selection of the primary, long-term source of tritium. This also allows the Department to review the economic and technical feasibility of using the FFTF to produce isotopes for the medical community. Formal direction has been received from DOE-RL and Fluor Daniel Hanford to implement the FFTF standby decision.

The objective of the Plan is maintain the condition of the FFTF systems, equipment and personnel to preserve the option for plant restart within three and one-half years of a decision to restart, while continuing deactivation work which is consistent with the standby mode.

The name Mobijtherm is mentioned on Pages $7,8,16$, and 23 of Appendix B. This is a trade name of the Mobil 0il Corporation.

TRADEMARK DISCLAIMER. Reference herein to any specific comercial product, process, or service by trade name, trademark, manufacturer, or otherwise, does not necessarily constitute or imply its endorsement, recommendation, or favoring by the united states Government or any ageney thereof or its contractors or subcontractors.

Printed in the United States of America. To obtain copies of $t$ 1s docthitent, contact: Doctuent Control Services, P.O. Box 950, Mailstop H6-08, Richland WA 993 Fax (509) 376-4989.

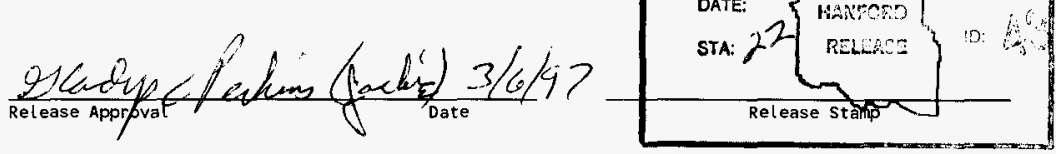

Approved for Public Release 
HNF-SD-FF-SSP-056

Revision 0

\title{
Fast Flux Test Facility
}

\section{Standby Plan}

Prepared for the U.S. Department of Energy Office of Environmental Restoration and Waste Management

\section{B\&W Hanford Company}

\author{
Richland, Washington
}

Project Hanford Management Contractor for the

U.S. Department of Energy under Contract DE-AC06-96RL13200

Approved for Public Release 
LEGAL DISCLAIMER

This report was prepared as an acooun of work sponsored by an agency of the United States Government. Neither the United States Govermment nor any agency thereof, nor any of their employees, nor any of their coturactors, subcontractors or their cmployees, makes any warranty, express or implied, or assumes any legal liability or responsibility for the accuracy, completeness, or any third party's use or the results of such use of any information, apparatus, proxtuct, or process disclosed, or represents that its use would not infringe privately owned rights. Reference herein to any specific commencial procuct, process, or service by trade name, trademark, marufacturer, or otherwise, does not necessarily constitule or imply its undorsement, recommendation, or favoring by the United States Government or any agency thereof or its contractors or subcontractors. The views and opinions of authors expressed herein do not necessarily state or reflect those of the United States Government or any agency thereof.

This report has been reproduced from the best available copy.

Printed in the Uritted States of Annerica

DISCIM-2.CHP (1-91) 
HNF-SD-FF-SSP-056

\section{Fast Flux Test Facility Standby Plan}

Revision 0

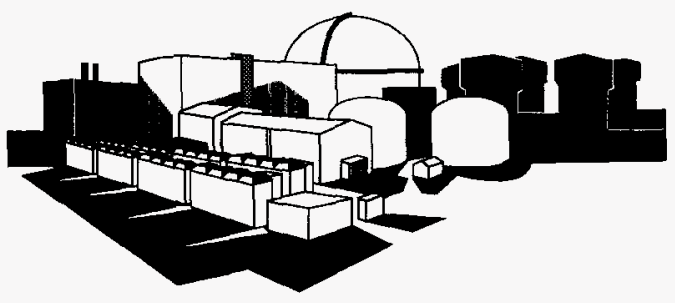

Prepared by

\section{B\&W Hanford Company}

March 6, 1997 
HNF-SD-FF-SSP-056

Rev. 0, Page 2

This page left intentionally blank. 
HNF-SD-FF-SSP-056

Rev. 0, Page 3

FAST FLUX TEST FACILITY STANDBY PLAN

Table of Contents

1.0 EXECUTIVE SUMMARY . . . . . . . . . . . . . . 7

2.0 SCOPE . . . . . . . . . . . . . . . . 9

2.1 TECHNiCAL OBJECTIVES $\ldots \ldots \ldots$

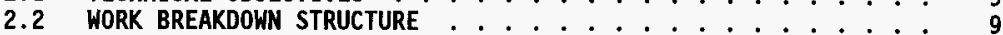

2.3 SCHEDULE . . . . . . . . . . . . . . . . 10

2.4 COSTS AND STAFFING .......................... 10

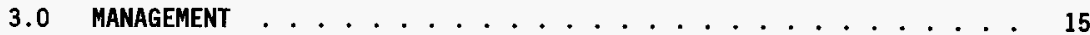

4.0 COMPLIANCE WITH ORDERS AND REgULATIONS ............. 17

4.1 DOE ORDERS . . . . . . . . . . . . . . . . 17

4.2 REGULATORY COMPLIANCE PLAN $\ldots \ldots \ldots$

4.3 WORKER HEALTH AND SAFETY $\ldots \ldots \ldots \ldots . \ldots . \ldots . . . \ldots 17$

4.3.1 Radiological Controls . . . . . . . . . . . . 18

4.3.2 Industrial Safety and Health ........... 18

4.3.2.1 S/RID Requirements . . . . . . . 18

4.3.2.2 Implementation of Safety Elements ...... 19

4.3.2.3 Performance Monitoring. . . . . . . . . 19

4.3.2.4 Fire Protection ............. 20

4.3.3 Emergency Preparedness . . . . . . . . . . . . . . 20

4.3.4 Criticality Safety .............. 21

4.4 QUALITY ASSURANCE REQUIREMENTS $\ldots \ldots \ldots$

4.5 ADMINISTRATIVE CONTROLS . . . . . . . . . . 21

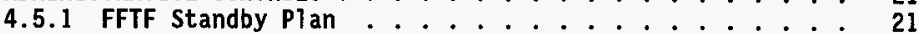

4.5.2 Final Safety Analysis Report . . . . . . . . . . 21

4.5.3 Criticality Specifications .......... 22

4.5.4 Readiness Reviews and Assessments . . . . . 22

5.0 DEACTIVATION ACTIVITIES . . . . . . . . . . . . . . 23

5.1 REACTOR DEFUELING . . . . . . . . . . . . . . . . 23

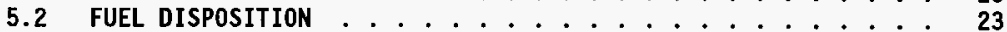

5.2.1 Category IVE Irradiated Fuel ............ 23

5.2 .2 Category IC/IIC/IIID Irradiated Fuel . . . . . . . 24

5.2 .3 Category IC Unirradiated Fuel . . . . . . . . . 24

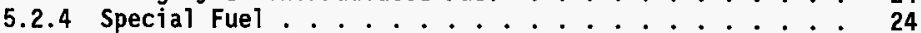

5.2.4.1 Delayed Neutron Monitor and Gas Leaker Fuel . 24

5.2.4.2 Sodium-Bonded Metal Fuel Test Assemblies . . 24

5.2.4.3 Unirradiated Metal Fuel Test Assembly .... 25

5.2.4.4 Carbide Fuel Test Assemblies ....... 25

5.2.4.5 Irradiated Fuel from 300 Area Stabilization
Project and ANL-West ......... 25

5.2.5 Non-Fuel Test Assembly Processing $\ldots \ldots$ 
HNF-SD-FF-SSP-056

Rev. 0 , Page 4

Table of Contents (continued)

5.3 FUEL OFFLOAD ...................... 26

5.3.1 Fuel Washing/Transfer Logistics ............ 26

5.3.2 Core Component Container .............. 27

5.3.3 Interim Storage Cask . . . . . . . . . . . . . . . 27

5.3.4 400 Area Interim Storage Area . . . . . . . . . . . 27

5.3.5 ISA Data Packages ................ 28

5.3.6 Fuel offload Status ............... 28

5.4 FUEL HANDLING EqUIPMENT MAINTENANCE ................. 29

5.4.1 Refuel ing Equipment ............... 29

5.4.2 IEM Cell Equipment ................ 29

5.4.3 IEM Cell Training Facility ............ 29

5.5 SODIUM DRAIN ACTIVITIES ................... . . . . 30

5.5.1 Sodium Drain Equipment Status . . . . . . . . . . . 30

5.5.2 Sodium Drain Documentation Status ......... 30

5.5.3 Sodium Storage Facility ............... . 31

5.5.4 Sodium Reaction Facility ............. . . 31

5.6 STANDARDS/REQUIREMENTS IDENTIFICATION DOCUMENT PROGRAM ....$\quad 31$

5.7 SODIUM LEGACIES ..................... . . 32

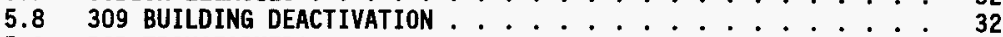

5.9 PCB TRANSFORMERS ................... 33

6.0 STANDBY ACTIVITIES . . . . . . . . . . . . . 35

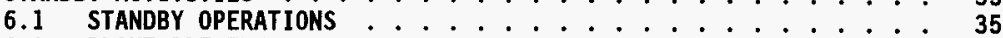

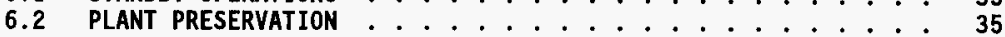

6.2.1 Operability Evaluation of Reactor Head-Mounted

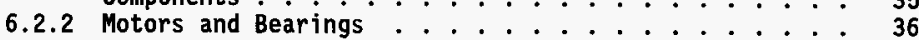

6.2.3 Preventative Maintenance ............. . 37

6.2.4 Spare Parts .................. 37

6.3 RECONSTITUTE TECHNICAL BASELINE ................ 37

6.3.1 Documentation ............... 37

6.3.2 Configuration Management ............. 38

6.3.3 Personnel ................. 38

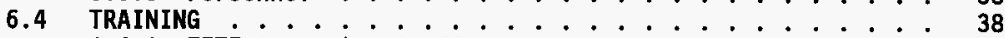

6.4.1 FFTF 0perating Staff ................ 38

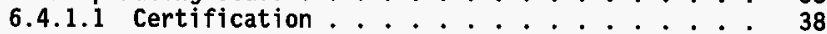

6.4.1.2 Training Accreditation ...................... 39

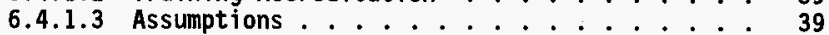

6.4.1.4 FFTF Training Simulator.................. 39

6.4.1.5 EDS Operating Staff............ 40

6.4.1.6 FFTF Maintenance Staff ........... 40

6.4.2 Technical Staff ................. 40

6.5 ENGINEERING STUDIES . . . . . . . . 41

6.6 ASME CODE PRESSURE BOUNDARY AND SEISMIC INTEGRITY ....... 41

6.7 PLANT SYSTEMS . . . . . . . . . . . . . . . . . 43

6.8 MAINTENANCE AND STORAgE FACILITY . . . . . . . . . . . . . 43

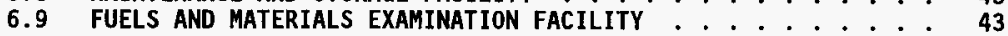


Table of Contents (continued)

7.0 NEW FFTF INITIATIVES . . . . . . . . . . . . 45

7.1 ENVIRONMENTAL STUDIES . . . . . . ........ 45

7.2 SAFETY ANALYSES . . . . . . . . . . . . . . . 45

7.2.1 Detailed P1 an Development . . . . . . . . . 45

7.2.2 Create FSAR Reference Library . . . . . . . . . . . 46

7.2.3 Perform Selected FSAR Safety Analyses . . . . . . 46

7.2.4 Sodium Spray Fire Models . . . . . . . . . . . . 46

7.2 .5 FSAR Revision ..................... 46

7.3 NATURAL PHENOMENA HAZARd and LifETime Evaluations $\ldots . . .46$

8.0 INFORMATION TO THE PUBLIC AND STAKEHOLDERS . . . . . . . 47

8.1 INTRODUCTION . . . . . . . . . . . . . . . . . 47

8.2 OBJECTIVE ..................... . . . 47

8.3 TPA MILESTONES ..................... 47

9.0 SAFEGUARDS AND SECURITY . . . . . . . . . . . . . 49

10.0 KEY ASSUMPTIONS, ISSUES AND ACTION ITEMS . . . . . . . . 51

10.1 KEY ASSUMPTIONS . . . . . . . . . . . . 51

10.2 ISSUES AND ACTION ITEMS ............... 53

11.0 REFERENCES . . . . . . . . . . . . . . 57

\section{$\underline{\text { List of Figures }}$}

Figure 1 ART Work Breakdown Structure ............... 11

Figure 2 FFTF Standby Plan Summary Schedule .................. 12

Figure 3 FFTF Standby Plan Annual costs ............... 13

Figure 4 FFTF Standby Plan Full-Time Equivalent Staff . . . . . . . 14

List of Tables

Table 5-1 fFTF SNF Component offload Status . . . . . . . . . . 28

\section{List of Appendices}

A FFTF Project Management

B FFTF Standby P1an System Status 
HNF-SD-FF-SSP-056

Rev. 0, Page 6

This page intentionally left blank. 


\subsection{EXECUTIVE SUMMARY}

The Secretary of Energy approved a Memorandum of Decision on January 17, 1997 (Reference 1) directing that the Fast Flux Test Facility (FFTF) is to be maintained in a standby condition to permit the Department of Energy (DOE) to make a decision on whether the facility should play a future role in the DOE dual track tritium production strategy. This decision would be made in parallel with the intended December 1998 decision on the selection of the primary, long-term source of tritium. Direction to implement the requirements of Reference 1 was provided from the DOE Richland Operations Office (RL) by Reference 2. The previous DOE directives (Reference 3 and Reference 4 ) regarding the shutdown of the FFTF are deferred by the January 17, 1997 decision.

Based upon an agreement between the Pacific Northwest National Laboratory (PNNL) and Fluor Daniel Hanford, Incorporated (FDH), a joint FFTF Standby Project Office (SPO) is being established to centralize management of the studies and analyses for potential FFTF missions, and maintain the FFTF in a standby status, while continuing the present FFTF deactivation work. The SPO will manage the supporting technical efforts of other facilities, particularly with regard to nuclear fuel supply, core engineering, accident analyses, and other technical areas. They will also provide a programmatic interface between the FFTF and DOE.

This Standby Plan, hereafter referred to as the Plan, defines the implementation of the standby directive by the FFTF. The prior FFTF Stabilization Project Plan (Reference 51) has been placed on hold and is superseded by issuance of this document. The intent of this Plan is to maintain the condition of the plant systems, equipment, and personnel to preserve the option for plant restart within three and one-half years of a decision to restart, while continuing deactivation work consistent with the standby mode. During the standby period, the SPO will direct a review of the safety and environmental analyses that could support nuclear safety or National Environmental Policy Act (NEPA) documents, and review the feasibility of using the FFTF to produce medical isotopes.

The structure of this Plan is consistent with DOE directives applicable to project management. It has been prepared as a working document and will be revised and augmented as additional information is developed. The technical requirements outlined in the $\mathrm{Plan}$ emphasize that maintaining the viability to return the FFTF to operation, as we11 as success in the conduct of future operations, requires diligent preservation of FFTF's unique technology and expertise.

It is understood that the December 1998 decision may be to return to the FFTF deactivation program. Therefore, all program documentation has been retained for those deactivation tasks that have been discontinued. The FFTF Stabilization Project Plan (Reference 51) will also be retained on file to serve as a planning document, if required. Selected deactivation work, consistent with the standby mode, will continue in accordance with the schedules of this Plan. 
HNF-SD-FF-SSP-056

Rev. 0 , Page 8

This page intentionally left blank. 


\subsection{SCOPE}

\subsection{TECHNICAL OBJECTIVES}

The technical objectives during the standby period are:

1) Maintain FFTF in standby while complying with the applicable federal, state, and local requirements. The standby tasks will preserve the capability for restart of the FFTF within three and one-half years if so directed by the DOE.

2) Maintain the Fuels and Materials Examination Facility (FMEF) in a condition to preserve the capability to support the FFTF if a decision is made to return the FFTF to operation.

3) Continue scheduled deactivation activities consistent with the standby mode, such as the cleaning and storing of spent nuclear fuel (SNF), and providing program integration for the deactivation of sodium legacy facilities and deactivation of the 309 Building.

4) Conduct safety and environmental analyses that could support nuclear safety or NEPA documentation if these are required at a later time. (This will be managed by the SPO.)

5) Review the economic and technical feasibility of using the FFTF to produce medical isotopes. (This will be managed the SPO.)

\subsection{WORK BREAKDOWN STRUCTURE}

The Advanced Reactors Transition (ART) Work Breakdown Structure (WBS) is shown on Figure 1. The WBS is based upon the technical objectives and will be used to integrate the technical, schedule, and cost baselines into one structure. This is to ensure that all technical scope is identified, facilitate the assignment of work, define interrelated activities, and establish milestones at key decision points. Figure 1 is arranged to show the Summary Work Breakdown Structure (SWBS) and the Contractor Work Breakdown Structure (CWBS). The SWBS provides the general framework for the work and the products to be produced. The CWBS provides a more detailed breakdown of the specific results and products to be produced.

Upon implementation of this Plan, the WBS will be developed to include the following functions:

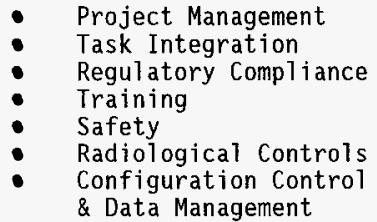

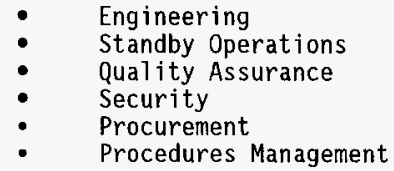


HNF-SD-FF-SSP-056

Rev. 0, Page 10

The WBS on Figure 1 also includes activities that are beyond the FFTF standby period. This is to indicate activities that would be required if a decision is made to use the FFTF for a new mission.

The WBS indicates those tasks which will be under the direction of the SPO. The SPO is currently being formed and will be managed by the PNNL and FDH. The WBS will be modified to incorporate changes that result from the formation of the SPO.

\subsection{SCHEDULE}

The summary schedule for this planning period is provided by Figure 2 . This schedule will be updated as additional direction or information is received. More detailed lower-tier schedules will be developed within the project and used for the planning of specific tasks and allocation of resources.

\subsection{COSTS AND STAFFING}

The work indicated in this Plan is constrained by the funding available. During the standby period, the identified tasks will be performed on a prioritized basis within the funding and staffing constraints. A program will be established to prioritize tasks and periodically identify specific work items that will be scheduled for accomplishment.

The current annual budgets through Fiscal Year (FY) 1999 are shown on Figure 3, including the distribution of costs between funding sources.

The planned FFTF Project staffing requirements are identified in Figure 4. This figure also shows the distribution of employees between the various funding categories. It should be noted that there are minimum staffing requirements that must be satisfied by authorized allocations. 

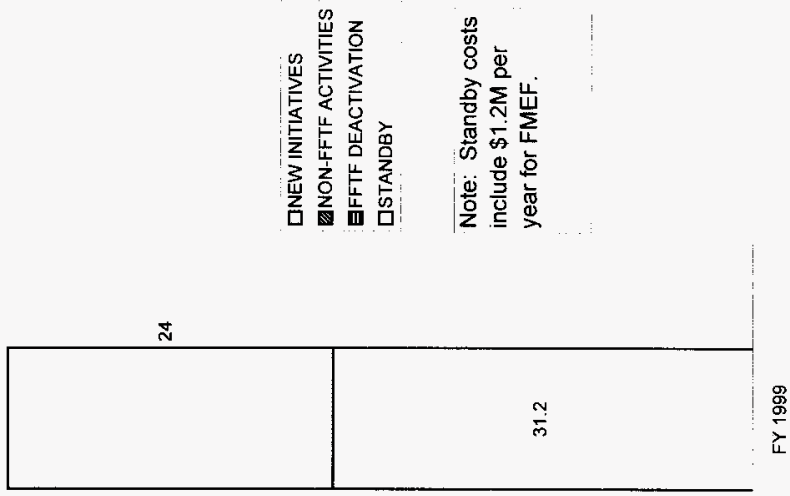

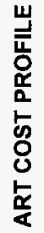
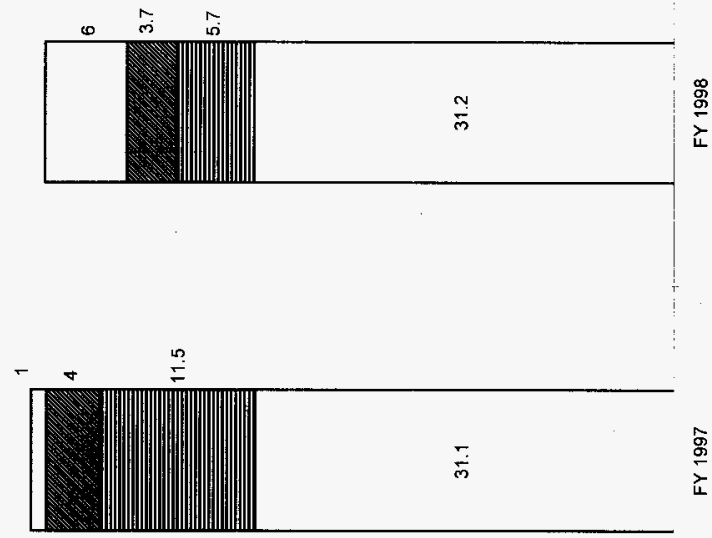

오

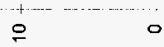




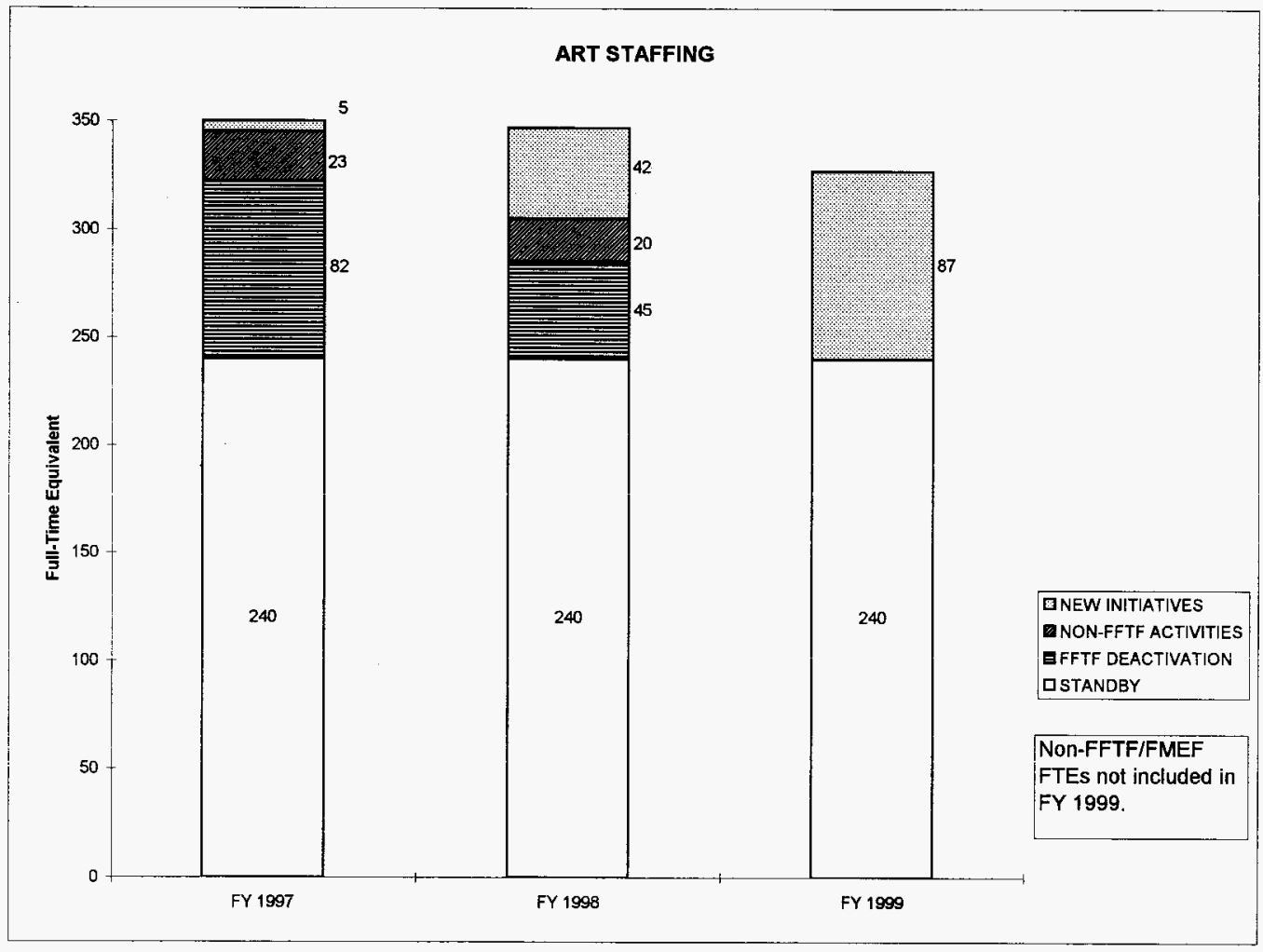

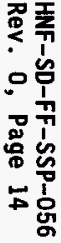

Figure 4 FFTF Standby Plan Full-Time Equivalent Staff 


\subsection{MANAGEMENT}

The approach to managing the FFTF Project, as defined by this P1an, is described in Appendix $A$, which addresses responsibilities, risks, baseline change control, cost estimating, and reporting during the FFTF standby period.

Management of the FFTF Project during the standby period will continue to follow the guidance in the DOE 4700.1 Project Management System (Reference 11) and the WHC-CM-2-5 Management Control System (Reference 42). DOE 4700.1 and WHC-CM-2-5 are referenced extensively throughout Appendix A. It is anticipated that DOE 4700.1 will be superseded by DOE 0 430.I Life-Cycle Asset Management (Reference 10) during FY 1997. It is also anticipated that Reference 42 will be superseded by a new Hanford Site change control procedure established by FDH. At the time either Reference 11 or Reference 42 is superseded, the FFTF Project will amend Appendix A as appropriate.

In the event a decision is made to use the FFTF and the supporting 400 Area facilities for a potential new mission, a new project plan will be prepared consistent with the "graded" project management approach of DOE 0430.1 . 
HNF-SD-FF-SSP-056

Rev. 0, Page 16

This page intentionally left blank. 


\subsection{COMPLIANCE WITH ORDERS AND REGULATIONS}

\subsection{DOE ORDERS}

Compliance with all applicable DOE Orders will continue during the FFTF standby phase and any subsequent mission. The FFTF Standards/Requirement Identification Document (S/RID) program identifies the applicable facility requirements and standards. Compliance surveillances are conducted to assure the requirements are achieved. The currently RL-approved S/RID requirements (Reference 54) are sufficient to maintain worker and public safety, and to protect the environment during the standby period.

\subsection{REGULATORY COMPLIANCE PLAN}

The FFTF will continue to maintain compliance with all applicable federal, state, and local laws and regulations during the standby period. In addition to ongoing surveillance and maintenance activities, certain deactivation activities will continue, such as cleaning and storing of SNF, and other reactor components. However, no activities will be conducted that would preclude restart of the facility. Other than routine compliance activities, no new permitting or regulatory actions have been identified at this time. The impacts of the deactivation activities were addressed in the FFTF Environmental Assessment (Reference 26).

The Fifth Amendment to the Hanford Federal Facility Agreement and Consent Order (Tri-Party Agreement) was issued in July 1995 (Reference 35) and subsequently revised in December 1996 (Reference 36). Established within Reference 35 and Reference 36 are major and interim milestones with target dates which address the transition of the FFTF to a safe deactivated state. The standby period will impact the achievement of milestone dates. Therefore, appropriate dialogue with the regulators must be initiated to discuss these impacts. Establishment of new milestones should be deferred until the future of the FFTF is clearly decided. The earliest anticipated date that new milestones could be established is after December 1998.

\subsection{WORKER HEALTH AND SAFETY}

Responsibility for worker health and safety begins with the DOE and is defined through DOE Orders and Directives. The specific requirements implemented at FFTF are identified in the FFTF S/RID (Reference 54). 
HNF-SD-FF-SSP-056

Rev. 0 , Page 18

\subsubsection{Radiological Controls}

The Radiological Controls program at the FFTF is directed by 10 CFR 835 (Code of Federal Regulations), Occupational Radiation Protection (Reference 31). This regulation is implemented on the Hanford Site by the Hanford Site Radiological Control Manual (HSRCM) (Reference 39) and at the FFTF by WHC-CM-4-27, Radiological Control Practices and Procedures (Reference 44). These documents provide the basis for the Radiological Controls program during the standby phase.

\subsubsection{Industrial Safety and Health}

Fundamental industrial safety and health activities which will continue while in standby include:

1) Identifying and analyzing work hazards.

2) Developing and implementing hazards controls.

3) Performing work within the controls.

4) Providing feedback on the adequacy of controls and continuous improvement of work.

The industrial safety and health program for the FFTF implements the procedures in the WHC-CM-1-10 Safety Manual (Reference 40) and the WHC-CM-1-11 Industrial Hygiene Manual (Reference 41). These manuals provide the necessary programs and guidance for rout ine work and conform to the requirements of the FFTF S/RID (Reference 54), which include: DOE 5483.1A, Occupational Safety and Health Program for DOE Contractor Employees at Government-0wned ContractorOperated Facilities (Reference 23); DOE 5480.4, Environmental Protection, Safety, and Health Protection Standard (Reference 12); and DOE 5480.10, Contractor Industrial Hygiene Program (Reference 14).

The Operating Contractor Safety Programs provide directives and guidance for the control of physical hazards; hazards identification, surveillance, and communication; asbestos removal operation; hazardous materials handling and emergency response; posting of danger signs and tags or safety instructional materials; storage of pressurized gases; lockout and tagout activities; fall protection; confined space; and explosive or combustible materials handling, processing, storage, transportation, and shipping. These programs are then implemented by the FFTF management and employees to ensure worker safety and health during plant operation and maintenance activities.

A general overview of the major programs is given below.

\subsubsection{S/RID Requirements}

Occupational safety and health requirements for the FFTF are included in the FFTF S/RID (Reference 54). These were developed for the previous shutdown mission and remain applicable for the standby phase. These will be revised if a decision is made to return the FFTF to operation. 


\subsubsection{Implementation of Safety Elements}

Incorporation of appropriate safety elements into the procedures used for operations and maintenance is fundamental to the FFTF conduct of operations program. Activities are analyzed for hazards and the results are incorporated in procedures which then receive the appropriate safety organization review (industrial, radiological, nuclear, etc.). This process is applied both to the standard operating and preventive maintenance procedures as well as the corrective maintenance and plant modification work instructions. This program provides the worker with a procedure which integrates the instructions for performing the task as well as specific safety precautions, protective equipment requirements, and exposure controls.

This program will continue to be used to prepare the work packages which govern the various standby activities. As a result, the same focus on worker safety demonstrated during the previous operating and shutdown phases will continue to be applied to the standby activities.

A Safety Improvement Plan was developed to implement the safety and health program. The plan merges employee and management goals and activities into one location making it easy to communicate and track actions to completion. The Safety Improvement Plan is formatted to ensure activities occur in each of the five tenets of the FFTF Voluntary Protection Program (i.e., Management Leadership, Employee Involvement, Worksite Analysis, Hazard Prevention and Control, and Safety and Health Training).

\subsubsection{Performance Monitoring}

Several programs are established for measuring the effectiveness of the plant safety programs. These programs will continue to be followed during the standby period.

1) The plant is routinely inspected by 0perations personnel to ensure that the plant remains free of safety hazards and that the standards of housekeeping are highly maintained. The plant is also inspected by the Shift Operations Manager, Operations Manager, a Maintenance Supervisor, and an Industrial Safety Engineer. The program has proven itself very effective based on the feedback from plant visitors and auditors who consistently praise the absence of safety hazards and the high standards of plant cleanliness.

2) In addition to the periodic inspections described above, the operations Manager conducts a thorough inspection of the plant annually. This manager has received training in the Occupational Safety and Health Act (OSHA) standards and utilizes an Annual Facility Safety Inspection Checklist prepared by Industrial Safety which verifies compliance with all the major elements of the OSHA standards. Plant physical conditions are inspected in addition to a review of the administrative programs in place.

3) A multifaceted internal self-assessment program is in place which conducts field verification of safe plant conditions and conformance to safe work practices. This program involves a team of 
HNF-SD-FF-SSP-056

Rev. 0, Page 20

representatives from the major plant organizations (including oversight functions) and utilizes a set of checklists developed to verify compliance with safety, operations, and maintenance programs. This program also identifies compliant activities which could be optimized. Actions identified by this program are entered into the plant's commitment tracking program.

An example of one of the self-assessment program activities is the Management Overview Program in which periodic tours of the plant are conducted to insure proper implementation of safe work practices. Prior to conducting their tour, the managers are briefed by the FFTF Project Director to receive guidance on areas that are to receive particular focus. Deficiencies identified are also documented and tracked to completion.

4) A "Safety First" Program is in place which is focused on ensuring that safe work practices are being followed by facility workers. This is a voluntary, behavioral-based safety observer program. The manager of Work Control reviews the scheduled work for each week and determines one or more jobs which warrant observation by one of the "Safety First" volunteers. The observations, good practices and deficiencies are documented.

Deficiencies and good practices are recorded and tracked in a database. Reports are sent to line management for corrective action. Lessons learned are distributed to appropriate organizations for dissemination to their personnet.

\subsubsection{Fire Protection}

During the standby mode, no measured enhancements or reductions in protection are expected beyond those that are currently in place. A fire hazards analysis is part of the existing Final Safety Analysis Report (Reference 38) (FSAR). Plans will be made to reverse the 1995 DOE decision to claim the FFTF plant as having "no property value" upon notification of direction for plant startup.

The required FFTF fire protection features are specified in WHC-CM-4-41 Fire Protection Program Manual (Reference 46). The intent is to fulfill the S/RID requirements which include; DOE 5480.7A, Fire Protection (Reference 13); and the National Fire Protection Association Standard 101, Life Safety Code, (Reference 33 ). The degree of fire protection is commensurate with the loss risk and risk to human health.

\subsubsection{Emergency Preparedness}

A Building Emergency Plan is maintained for the FFTF Property Protection Area (Reference 49). The plan identifies specific facility hazards, and defines the anticipated responses to emergency conditions. When used in conjunction with the DOE/RL-93-75 Hanford Facility Contingency P1an (Reference 27), and the DOE/RL-94-02 Hanford Emergency Response PIan (Reference 28), all requirements for contingency planning are satisfied. The documents also identify lines of authority and the responsibilities of emergency response 
personnel and organizations. Implementation is completed through the WHC-CM4-43 Emergency Management Procedures (Reference 47) and FFTF procedures.

Transition of the WHC-CM-4-43 Emergency Management Procedures (Reference 47) and the FFTF Building Emergency Plan (Reference 49) to a new internal FFTF procedure system will take place by 0ctober 1997.

\subsubsection{Criticality Safety}

Chapter 20 of the FSAR (Reference 38) and the WHC-CM-4-29 Nuclear Criticality Safety Manual (Reference 45) establish the Nuclear Criticality Safety Program. Operating, standby, and deactivation activities with criticality implications are reviewed by the FFTF Criticality Safety Representative (CSR) and the Safety organization to ensure that the proposed work is within the existing Criticality Prevention Specifications.

Whenever changes are made that impact the handling or storage of nuclear fuel components, the criticality prevention procedures will be prepared, or modified, and approved to assure compliance with criticality prevention specifications.

\subsection{QUALITY ASSURANCE REQUIREMENTS}

The FFTF Quality Assurance Program implements the requirements and procedures in WHC-CM-4-2 (Reference 43). This implements the requirements of DOE 5700.6C (Reference 25) and 10 CFR 830.120 (Reference 29).

\subsection{ADMINISTRATIVE CONTROLS}

\subsubsection{FFTF Standby P1an}

The Plan defines the major elements and identifies the intended standby period activities to provide clear direction for management of the work. The Resource Loaded Schedule (RLS) (Reference 52) will be developed based upon this Plan and used with the WBS (Figure 1) to control the work performed during the standby period. The Plan will be updated at least annually to best apply the available resources towards the intended goals. Section 10.0 identifies the assumptions and unresolved issues of this Plan.

\subsubsection{Final Safety Analysis Report}

The FFTF began operations in 1980 based upon the original issue of the FSAR (Reference 38) and the included Technical Specifications (Chapter 17 of the FSAR). The FSAR has been maintained current through an Engineering Change Notice (ECN) process. 
HNF-SD-FF-SSP-056

Rev. 0, Page 22

Since the shutdown began in 1992, technical updates have been continued through the ECN process, but the DOE Orders listed below have not been fully implemented.

DOE 5480.22 Technical Safety Requirements (Reference 17)

DOE 5480.23 Nuclear Safety Analysis Reports (Reference 18)

DOE 5480.28 Natural Phenomena Hazards Mitigation (Reference 19)

DOE 5480.30 Nuclear Reactor Safety Design Criteria (Reference 20)

The degree of implementation of the DOE Orders is reflected in the RL-approved S/RID for the FFTF (Reference 54). The currently approved S/RID requirements (Reference 54) are sufficient to maintain worker and public safety and health, and to protect the environment during the standby period.

During the standby period, the FSAR, including the Chapter 17 Technical Specifications, will continue as the Authorization Basis to support FFTF operations.

\subsubsection{Criticality Specifications}

The Criticality Prevention Specifications in Chapter 20 of Reference 38 describe physical limitations and establish administrative limits on the handling of fissile material, such as nuclear-fueled components, to prevent a criticality accident. When engineered features to prevent a criticality are not available, conservative Administrative Limits are set by the appropriate Criticality Safety Engineering Report, and incorporated into the Criticality Prevention Specifications by an ECN.

\subsubsection{Readiness Reviews and Assessments}

No additional Readiness Reviews (RR) or Readiness Assessments (RA) are planned during the standby period. The following assessments have been completed and support the ongoing SNF component washing and storage activities:

1) SNF Fuel Washing (RA)

DOE 5480.31 (Reference 21)

RLID 5480.31 (Reference 22)

2) SNF Fuel Storage (RA)

DOE 5480.31 (Reference 21)

RLID 5480.31 (Reference 22)

A Readiness Assessment was conducted for the Sodium Storage Facility (SSF)

(Section 5.5.3). The SSF is being maintained in standby. 


\subsection{DEACTIVATION ACTIVITIES}

The major deactivation activities that will be completed at the FFTF and the related facilities during the standby period are identified within this section. The SNF offload activities are subdivided into the following major activities: disposition of irradiated fue ${ }^{1}$ components, disposition of special fuel, and disposition of long (non-fuel) assemblies, as described in Sections 5.1 through 5.3 .

\subsection{REACTOR DEFUELING}

The defueling of the reactor to Interim Decay Storage (IDS) and the Fuel Storage Facility (FSF) was completed on April 19, 1995. Nuclear fuel in the reactor vessel was replaced with irradiated non-fueled core components (e.g., reflectors, control rods, etc.) and 17 new non-fueled core components that were to be excessed. The In-Vessel Handling Machines (IVHMs) and Instrument Trees (ITs) were left in their removal positions (centered under their respective reactor head plug). The Control Rod Drive Mechanisms (CRDMs) were also left in a configuration to facilitate removal from the reactor vesse 1 head. Two core locations were left vacant to provide vessel access for the installation of dip tube(s) for draining the residual sodium from the reactor vessel during the sodium drain activities. Also, two immersion heaters and an instrumentation assembly were inserted into the Fuel Transfer Ports in In-Vessel Storage to provide a redundant heat source for the sodium during the drain evolution. Reference 1 placed the sodium drain activities on hold.

\subsection{FUEL DISPOSITION}

\subsubsection{Category IVE Irradiated Fuel}

Disposition of irradiated Category IVE special nuclear material (SNM), according to DOE 5633.3B (Reference 24), necessitates placing the fueled components in interim storage. The planned disposition of the Category IVE highly-radioactive ( $>100 \mathrm{rem} / \mathrm{hr}$ at 1 meter unshielded) fueled components entails placing them in Interim Storage Casks (ISCs) (Section 5.3.3) and storing them in the 400 Area Interim Storage Area (ISA) (Section 5.3.4). Since the FFTF fueled components are currently stored in sodium, they must be washed prior to loading into an ISC (Section 5.3.1). Washing of the FFTF spent nuclear fuel has been underway since December 1995. Several ISCs are now loaded with washed SNF and are stored in the 400 Area ISA.

It is important to note that because these fueled components are continuing to radioactively decay, they must be packaged to permit their potential transfer to a more secure area, or the 400 Area ISA must be reclassified, when the first Category IVE fueled component decays to $100 \mathrm{rem} / \mathrm{hr}$ at 1 meter unshielded (Category III). It is estimated that this will occur no sooner than the year 2008.

Only Category IVE SNM that has been evaluated and determined to be of no use

1 Use of the term fuel is synonymous with nuclear fuel, or reactor fuel. 
HNF-SD-FF-SSP-056

Rev. 0, Page 24

to a future mission will be washed and loaded into an ISC during the standby period.

\subsubsection{Category IC/IIC/IIID Irradiated Fuel}

Disposition of the slightly and moderately-radioactive Category IC, IIC and IIID irradiated SNM as defined per DOE 5633.3B (Reference 24), and described in the FFTF Stabilization Project Plan (Reference 51), will be placed on hold during the standby period pending direction for future missions.

\subsubsection{Category IC Unirradiated Fuel}

Planned disposition of the unirradiated Category IC SNM as defined in DOE 5633.3B (Reference 24), and described in the FFTF Stabilization Project Plan (Reference 51), will be placed on hold during the standby period pending future mission direction.

\subsubsection{Special Fuel}

\subsubsection{Delayed Neutron Monitor and Gas Leaker Fuel}

There are currently two intact assemblies ( $\mathrm{ACN}-1$ and $\mathrm{PO}-4$ ) that produced delayed neutron monitor signals while in the reactor. There are additional fueled core components (nine) that were identified as gas leakers during operation. These fueled components will not be processed in the Sodium Removal System at this time to minimize the consequences of potential contamination release and resultant deposition in the sodium removal equipment, which would make equipment maintenance more difficult.

\subsubsection{Sodium-Bonded Metal Fuel Test Assemblies}

Six irradiated fueled components, containing sodium-bonded metal fuel pins, one unirradiated sodium-bonded metal fuel assembly (Section 5.2.4.3), and one Fuel Pin Storage Container (Ident-69) from previously disassembled assembly IFR-1 are planned to be shipped to the Idaho National Engineering and Environmental Laboratory (INEEL) for consolidation with the Experimental Breeder Reactor-II (EBR-II) metal fuel inventory. The assemblies will be washed in the Interim Examination and Maintenance (IEM) Cell and transported in 7 icensed T-3 casks. An addendum to the license for the T-3 cask is required to minimize the number of shipments. This addendum has been prepared and submitted to DOE for approval, which is expected in FY 1998. Shipment of the metal fuel to the INEEL was scheduled to occur prior to December 23, 1998 in order to support completion of the FFTF fuel offload activity. This would subsequently allow the remainder of the sodium systems to be drained and the associated auxiliary systems to be shut down. However, shipment of these experimental assembi ies has been delayed for an indefinite period under the terms of a Consent Order agreed to by the DOE, the Department of Defense, and the State of Idaho. The Consent Order was filed in the U.S. District Court for the District of Idaho on October 17, 1995 (Reference 37). This delays shipment of DOE SNF, including the metal fuel at the FFTF, to the INEEL until after December 31, 2000 at the earliest.

A white paper "Impacts of Delaying Shipment of the Sodium-Bonded Fuel to the 
Idaho National Engineering Laboratory and Interim Disposition Options," (Reference 6 ) was issued which examined four potential storage and transfer options based on delayed shipment of the metal fuel to the INEEL. The primary factor considered in preparing this evaluation and recommendation was to select the best technical approach for completing the FFTF shutdown in a cost effective, environmentally responsible, and safe manner.

The delay in shipment of the metal fuel to the INEEL could be extended for a variety of reasons such as shipping priority, budget reductions and changing political considerations. Before the direction to place the FFTF in standby was received, the option selected was to store the metal fuel in ISCs in the 400 Area ISA. This option supported the potential continuation of deactivation with minimum schedule impact. Also, this option provided the best storage configuration from a technical, safety, and cost bas is should transfers to the INEEL be delayed for several years. Included in this recommendation was the eventual transfer of the ISCs to the Canister Storage Building (CSB) currently being constructed on the Hanford Site. Limited modifications of the CSB will enable transloading of the metal fuel into T-3 casks for shipment to the INEEL when agreement is reached. This planned disposition of the irradiated metal fuel will be placed on hold during the standby period pending future mission direction. If a shipment window to INEEL can be identified while the FFTF remains operational, it is preferable and cost-effective to offload directly to the T-3 shipping casks.

\subsubsection{Unirradiated Metal Fuel Test Assembly}

One unirradiated metal fuel assembly containing sodium-bonded $\mathrm{U}-10_{2 r}$ alloy fuel is currently stored in the Test Assembly Conditioning Station (TACS). This unirradiated assembly will be retained during the standby period pending future mission direction.

\subsubsection{Carbide Fuel Test Assemblies}

There are three carbide-type fuel test assemblies located at the FFTF. The path forward for these test assemblies is being evaluated at this time. Once the decision has been reached on the final disposition, the assemblies will be packaged in an ISC and placed in interim storage at the 400 Area ISA, or shipped in a T-3 Cask to another location for final dispositioning.

\subsubsection{Irradiated Fuel from 300 Area Stabilization Project and ANL-West}

The FFTF had one irradiated assembly with lithium-bonded pins. This assembly (FSP-1R) was washed and disassembled in the IEM Cell, and the pins were sent to the 300 Area for 1 ithium removal. The cleaned pins will be returned to the FFTF in FY 1997 for storage in an ISC.

Efforts are also under way to return irradiated FFTF fuel pins and remnants currently stored at various locations within the 300 Area Stabilization Project. These Ident-69 containers will be shipped using the T-3 Cask. The Ident-69 containers will be processed in the same manner as other Ident-69 containers located at the FFTF and placed into ISCs for interim storage in the 400 Area ISA. 
HNF-SD-FF-SSP-056

Rev. O, Page 26

ANL-West at the INEEL has approximately 249 irradiated FFTF fuel pins stored in their facility. The pins were examined as part of a fuels and material experimental program in support of the Liquid Metal Breeder Reactor program. Discussions are being held to support transferring that material back to the FFTF in Ident-69 containers for interim storage in ISCs. This material will follow the same path forward as the irradiated fuel described in Section 5.2.1 and 5.2.2.

\subsubsection{Non-Fuel Test Assembly Processing}

There are a total of 21 0pen Test Assembly instrument stalks located in the TACS and in the IDS. The Materials 0pen Test Assembly (MOTA) stalks are $40 \mathrm{ft}$ long including the canister tree which contained the material specimens. Each of the Fuel 0pen Test Assemblies (FOTA) stalks and the Post Irradiation Open Test Assemblies (PIOTA) stalks are $28 \mathrm{ft}$ long. The bottom 30 feet of the MOTA stalks and the bottom 18 feet of the FOTA and PIOTA stalks are radioactive and sodium-wetted. Eighteen irradiated stalks are stored in the TACS, and three unirradiated PIOTA stalks are stored in Row A of the IDS. There are also two Hanford Engineering Development Laboratory (HEDL) materials assemblies presently stored in the FSF.

Current plans are to transfer those long components, which will not be used in the event of a reactor restart decision, into the IEM Cell where they will be sheared into $12 \mathrm{ft}$ lengths, washed to remove sodium residuals, and placed into Disposable Solid Waste Casks (DSWCs) for burial in the 200 Area. The two materials assemblies will also be transferred into the IEM Cel1, washed, and offloaded for disposal with the long assemblies.

\subsection{FUEL OFFLOAD}

\subsubsection{Fuel Washing/Transfer Logistics}

Fuel is transferred from the FSF and the IDS fuel storage vessels to the IEM Cell for sodium removal and placement into Core Component Containers (CCCS). The CCCs are then transferred to the Cask Loading Station for placement into ISCs. Finally, the ISCs are placed in the 400 Area ISA for interim storage.

The sodium-wetted fueled components are transferred one at a time to the IEM Cell for washing utilizing both the Bottom Loading Transfer Cask (BLTC) and the Closed Loop Ex-vessel Machine (CLEM). The BLTC transfers the fuel from either the FSF or IDS fuel storage locations to the Core Component

Conditioning Station South. Each component is then placed in a dry core component pot which is then moved into the IEM Cell by the CLEM.

The fuel is washed one assembly at a time in the IEM Cell Sodium Removal System, dried, and placed in a clean CCC. When the CCC is filled, it is closed and sealed for transfer out of the cell via the Solid Waste Cask (SWC).

The SWC transfers the loaded CCC to the Reactor Service Building Cask Loading Station where the CCC is placed into an ISC, which is inerted with helium and sealed. The ISC is then transferred to the 400 Area ISA for interim storage. 
Approximately 13 days are required to complete a cycle of washing and transferring seven fueled components to an ISC. Since these activities, consisting of transfers, washing, and drying, have been performed as part of the processing cycle for 14 ISCs, the schedule estimates for fuel offload are presented with a high degree of confidence.

\subsubsection{Core Component Container}

The CCC is a closed container that provides packaged-handling capability and geometry control for the FFTF components (fuel assemblies and Ident-69s) for the 50-year design 1 ife of the dry cask storage system. The CCCs are fabricated from stainless steel and inconel to provide corrosion resistant fuel storage. The design provides a separate tube for each fueled component. Prior to storage in a CCC, each fueled component is washed in the IEM Cell Sodium Removal System.

The CCC can accommodate a maximum of seven driver fuel assemblies (DFA), or six Ident-69s, or a combination of seven fueled components with no more than five being Ident-69s. The CCC design supports current handiing and future fuel retrieval operations.

The cleaned fueled components are loaded into a CCC in the IEM Cell and inerted with argon. The lid is then installed and a leak test performed on the metal seal. After acceptance, the sealed CCC is transferred in the SWC to the Cask Loading Station where the CCC is placed into an ISC.

\subsubsection{Interim Storage Cask}

The ISC is a top-loading shielded cask capable of receiving and storing a CCC containing up to seven FFTF irradiated fueled components. The ISC design consists of a passively-ventilated concrete and steel shielded cask with a stainless steel confinement boundary. Maximum weight of the cask, with the 5,000 pound $C C C$ payload, is 114,200 pounds. An impact limiter located at the bottom of the internal cavity of the ISC will protect the SNF from damage if an inadvertent drop of the CCC were to occur during loading. After the loaded CCC is placed in the ISC, the cask is sealed by bolting down the shielded cover and tested to ensure the redundant metal seals are functional. The ISC is inerted with helium and, although monitoring is not planned, provision for intermittent monitoring of the annulus between the seals is provided.

\subsubsection{Area Interim Storage Area}

The 400 Area ISA is located in the northeast corner of the FFTF complex. This fenced storage area is illuminated by perimeter overhead lighting. The ISCs are stored on the concrete pad located within the fenced area. A locked gate provides controlled access to the storage area. The maximum design radiation level at the ISA fence is limited to $0.05 \mathrm{mrem} / \mathrm{hr}$.

Spent nuciear fuel from the 308 Building is also stored in casks inside a concrete storage vault within the ISA. 
HNF-SD-FF-SSP-056

Rev. 0, Page 28

\subsubsection{ISA Data Packages}

Data packages, documenting each of the fueled components stored in ISCs and located within the 400 Area ISA, will be required in preparation for long-term storage of the fueled components. These data packages will be prepared during the standby period as resources become available. These packages will contain information on the design, fabrication, irradiation, and handling of the components along with supporting analyses. These are required for the ultimate disposal of the SNF in a national repository.

\subsubsection{Fuel Offload Status}

The FFTF efforts are currently focused on washing and offloading SNF components that have been analyzed and released for dry cask storage. Those components that have insufficient remaining 1 ife, and are highly radioactive, are being identified for washing and offloading. The status of the FFTF SNF offload program as of March 1, 1997 is shown in Table 5-1.

\begin{tabular}{|c|c|c|}
\hline \multicolumn{3}{|c|}{$\begin{array}{c}\text { Table 5-1 FFTF SNF Component offload Status } \\
\text { March } 1,1997\end{array}$} \\
\hline Description & Reference & Quantity \\
\hline Unirradiated Components ${ }^{1}$ & $\begin{array}{l}5.2 .3 \\
5.2 \cdot 4 \cdot 3\end{array}$ & 33 \\
\hline Irradiated Low Activity Components ${ }^{1}$ & 5.2 .2 & 20 \\
\hline Irradiated High Activity Components - Cask Loaded & 5.2 .1 & 98 \\
\hline Irradiated Fueled Components Pending Disposition & & 222 \\
\hline Total Components in Storage at FFTF & & 373 \\
\hline \multicolumn{3}{|c|}{$\begin{array}{l}\text { These categories will not be washed and offloaded during the standby } \\
\text { period. }\end{array}$} \\
\hline
\end{tabular}

Analysis is ongoing for release of the 222 SNF components in Table 5-1 that are pending disposition. Based on previous release criteria, up to 50 of the 222 components pending disposition could be released for washing and storage during the standby period.

The ongoing procurement of 57 CCCS and 30 ISCs to support fuel offload will be completed in FY 1997. If a decision is made to continue with the FFTF deactivation, the procurement of additional storage equipment will be required. 


\subsection{FUEL HANDLING EQUIPMENT MAINTENANCE}

\subsubsection{Refueling Equipment}

A refueling equipment maintenance period is expected during the standby period after completion of the current ISC loading campaign. This will allow performance of required preventive and corrective maintenance activities on the major refueling equipment and systems, which include the following:

Closed-Loop Ex-Vessel Machine (CLEM)

Bottom Loading Transfer Cask (BLTC)

Solid Waste Cask (SWC)

Multi-Purpose Rail Transporter (MPRT)

Interim Decay Storage (IDS)

Cask Loading Station (CLS)

Core Component Conditioning Station (CCCS)

Test Assembly Conditioning System (TACS)

The existing fuel handling equipment contains obsolete control components, and equipment failure could significantly impact the fuel offload schedule. The standby period provides an opportunity to evaluate, engineer, and install, selected reliability enhancement modifications that improve the deactivation schedule.

Resources are required both to support the planning and preparations for this specific maintenance window as well as the engineering, maintenance, operations, and other facility support needed for any unplanned maintenance and repair to keep the cask loading activity on schedule.

\subsubsection{IEM Cell Equipment}

An IEM Cell equipment maintenance period will be scheduled during the standby period to perform required preventive and corrective maintenance activities on the major IEM Cell equipment. This equipment includes the Sodium Removal System (SRS), Shielded Cell Transfer Cask (SCTC), Ion Exchange System resin bed, and the CLEM grapple cleaning equipment.

As with the refueling equipment, reliability enhancements will be performed on the IEM Cell equipment. The scope for these enhancements will be further refined during the standby period.

\subsubsection{IEM Cell Training Facility}

The IEM Cell Training Facility at the 309 Building (300 Area) has several facility cranes and hoists that are in the FFTF preventative maintenance program. These preventative maintenance activities will be performed only on an as needed basis.

The IEM Cell Training Facility will be needed in support of shear testing for the long assembly processing described in Section 5.2.5. There are currently no other defined activities for the training facility during this standby period except the potential support that may be necessary to resolve unplanned IEM Cell equipment problems. 
Due to the planned 309 Building deactivation, an evaluation of the need to retain the IEM Cell Training Facility will be completed and recommendations provided. Since entry into the FFTF IEM Cell is prohibited due to high radiation levels and the cell's inert atmosphere, it may be very desirable to retain the IEM Cell Training Facility by moving it from the 309 Building to another location, or isolating it from the rest of the 309 Building. This decision must be made in time to support deactivation of the 309 Building which is scheduled to occur in FY 2000.

\subsection{SODIUM DRAIN ACTIVITIES}

\subsubsection{Sodium Drain Equipment Status}

Considerable progress had been made on preparing for the drain of the sodium and NaK systems prior to receiving direction to maintain the FFTF in standby. This includes the identification, design, fabrication, procurement, and testing of special equipment required to accomplish the various drain activities. The equipment consists of:

- Five manual level probes.

- Three IHX dip tubes.

- Two reactor vessel immersion heater assemblies.

- One nitrogen blower heater unit (NBHU).

- One-inch bellows sealed valves for sodium-to-NaK cross-connects.

All of this special equipment is identified and described in various work packages in the Job Control System (JCS), and will be retained for future use if it is decided to resume the FFTF shutdown activities.

The major sodium drain activity during the standby period will be completion of the nearly full-scale development testing of the reactor vessel inlet plenum drilling equipment. The testing has been completed and included drilling of a $3 / 4^{\prime \prime}$ diameter hole through a $3^{\prime \prime}$ thick stainless steel plate using a five foot long drill bit on a forty foot long drive shaft. Testing of the ability to ream the upper portion of the core basket receptacle tube (through which the drill bit must pass) was also performed. The test results will be documented in a supporting document by April 1, 1997, and the equipment developed to perform the drilling/reaming operation will be stored for future use.

\subsubsection{Sodium Drain Documentation Status}

All documents related to sodium drain are being retained by the FFTF organizations. As examples, these documents include numerous ECNs, supporting documents (SD), drawings, work packages, test specifications, test procedures, and correspondence which have been generated to support drain activities. Where appropriate, these documents have been entered into the site records management system. The ECNs, SDs, and drawings have been released through the Engineering Release System (ERS) database. Work packages written in support of sodium drain activities have been identified (using a unique designator in the Administrative Code field) in the FFTF JCS. The work packages related to sodium drain will be retained by the JCS office. Documents which are not in the ERS database or JCS are available in the Records Management Information 
System (RMIS), or the FFTF Engineering files. RMIS is used to catalog the images of all inter-company correspondence sent throughout the site. Therefore, any document sent to another contractor, or to the DOE, is available in the database. Every effort has been made to safeguard the record of work that has been performed to prepare for sodium drain.

\subsubsection{Sodium Storage Facility}

Construction of the SSF at the FFTF was completed on October 30, 1996. The SSF contains three 80,000 gallon and one 52,000 gallon vessels to receive 260,000 gallons of sodium from the FFTF sodium systems, including the sodium in the Interim Decay Storage Vessel and the Fuel Storage Facility.

The SSF and the connecting piping from the FFTF will be maintained in standby at ambient temperature under an inert gas blanket until needed. Additional information about the SSF can be found in the FFTF Stabilization Project Plan (Reference 51).

\subsubsection{Sodium Reaction Facility}

A Sodium Reaction Facility (SRF) was planned to be located adjacent to the SSF to convert the sodium to a useable product or to a stable waste form. The preparation of the Functional Design Criteria and the Conceptual Design Report for the SRF was placed on hold by Reference 5. Additional information about the SRF can be found in the FFTF Stabilization Project Plan (Reference 51). The FFTF personnel will continue to follow the startup and operation of the INEEL Sodium Processing Facility in the event a SRF is required to react the FFTF sodium.

\subsection{STANDARDS/REQUIREMENTS IDENTIFICATION DOCUMENT PROGRAM}

Recommendation 90-2 from the Defense Nuclear Facility Safety Board (DNFSB) suggested that the $\mathrm{DOE}$ and its Contractors identify standards and requirements adequate to protect the environment, the public, and facility workers. The DOE directed implementation of an S/RID program for all Hanford facilities classified as Hazard Category 1 or 2.

The FFTF project maintains an S/RID program that identifies the applicable facility requirements and standards. Compliance surveillances are conducted to assure the FFTF meets the requirements. The FFIF S/RID (Reference 54) is sufficient to maintain worker and public safety, and protect the environment during the FFTF standby period. This also applies to the fuel offload activities. 
HNF-SD-FF-SSP-056

Rev. 0 , Page 32

The FFTF S/RID program includes the following activities:

1) Maintaining the S/RID requirements listings current with the changing DOE Orders, and government laws and regulations.

2) Maintaining the implementing documentation lists and database current as the Hanford Site controlled manual system is updated and adjusted to meet the new Hanford contractor organization needs, and as the FFTF procedures are updated and changed.

3) Performing and documenting compliance assessments to provide confidence that the conditions and activities at the FFTF conform to the implementing documents.

4) Documenting and tracking corrective actions identified in the compliance assessments.

The FFTF S/RID program will be required as long as the FFTF is categorized as a Hazard Category 1 or 2 facility.

\subsection{SODIUM LEGACIES}

The activities described below are scheduled to be performed during the FFTF standby period within budget constraints.

1) Drain the sodium from the two large tanks (1720-DR and 3718-M) into rail cars and ship to the buyer.

2) Drain the NaK from the cold trap cooling jacket for the 337 Building sodium loop into an approved shipping container.

3) Clean residual sodium from several tanks previously drained.

4) Cut up the small sodium loop in the 221-T Building and dispose of as waste (assumes that the material can be released as nonradioactive).

5) Move the 221-T Building sodium tanks to the 300 Area and drain.

6) Evaluate cleaning and draining options for the Composite Reactor Component Test Activity tank in the 337 Building.

7) Finalize planning and preparation for removing the sodium and NaK piping from the 337 Building sodium loop.

Throughout the period, support will be provided for the Cooperative Research and Development Agreement (CRADA) with LM Manufacturing of Marysville, Washington. This support will consist mainly of shipping items that are not sodium-wetted to LM.

\subsection{BUILDING DEACTIVATION}

Deactivation of the Plutonium Recycle Test Reactor (PRTR) 309 Building will continue during the FFTF standby period. Completion of the 309 Building 
deactivation activities is projected to occur in FY 2000. Activities to be completed are described in the 309 Building Transition P1an (Reference 50). The schedule is subject to baseline change control and is maintained in the RLS (Reference 52). The Advanced Reactors Transition Fiscal Year Multi-Year Work Plan (Reference 53) will provide the updated authorization for the workscope in each fiscal year. Reference 52 and Reference 53 will be revised to reflect the directive to maintain the FFTF in standby.

The FFTF staff will determine the final disposition of the IEM Cell training facility and mockup located in the 309 Building. If it is decided in 1998 that the FFTF will be returned to operation, a decision will be made as to the need for the IEM Cell training facility, and actions will be taken to support the 309 Building deactivation schedule.

\subsection{PCB TRANSFORMERS}

Disposition of the nineteen polychlorinated biphenyl (PCB) electrical transformers at the FFTF was required during the previous FFTF stabilization phase. Five transformers have been drained and removed to date. To allow removal of three of the PCB transformers, power to some electrical loads were either transferred to remaining power sources or permanently disconnected. The other two removed PCB transformers were not in use. If the FFTF is returned to operation, a $\mathrm{plan}$ will be developed to restore necessary transformer capacity to provide power to the required equipment.

Tri-Party Agreement (TPA) Milestone M-81-06 (Reference 35) delineates the agreed upon disposition of the PCB transformers. The removal of the 14 remaining transformers has been placed on hold as a result of the Reference 2 directive. The TPA milestone must be renegotiated. 
HNF-SD-FF-SSP-056

Rev. 0, Page 34

This page intentionally left blank. 


\subsection{STANDBY ACTIVITIES}

\subsection{STANDBY OPERATIONS}

Examples of the FFTF, FSF, FMEF, MASF, and other 400 Area support building activities that are required during the standby period include:

1) Monitoring and operation of plant equipment.

2) Planning and performance of corrective and preventive maintenance.

3) Safety, quality assurance, and health physics surveillances, assessments, and oversight.

4) Security and surveillance of plant property and SNM.

5) Training and qualification programs.

6) Procurement and management of supplies and consumable items.

A majority of the FFTF systems are still required to be in operation to support the storage of reactor fuel, operation of liquid sodium systems, and to furnish general building utilities. Most systems that were no longer needed after fuel was removed from the reactor vessel have been previousiy secured. In addition, some equipment such as standby heating and ventilating (H\&V) units have been maintained in a configuration requiring minimal maintenance. During the standby period, the remaining necessary systems and equipment will be maintained in a condition to support future FFTF activities as described in Section 6.2 for plant preservation.

\subsection{PLANT PRESERVATION}

The FFTF equipment has been systematically reviewed to determine actions that need to be performed to preclude further degradation, which could impact the ability to restart within three and one-half years of notification. The review was performed by a team from Operations, Engineering and Maintenance management along with each of the plant system mechanical and electrical cognizant engineers. The review focused on the current system status, JCS records of outstanding work documents (both active and inactive), and preventative maintenance activities which had been suspended due to the planned transition to $\mathrm{plant}$ shutdown. The key results of this review are included in Appendix B, while the strategy and highlights are discussed below.

\subsubsection{Operability Evaluation of Reactor Head-Mounted Components}

Operability of the reactor head-mounted mechanical components, consisting of the IVHMs, ITs, CRDMs, Control Rod Drive Lines and Low Level Flux Monitors (LLFM) is of particular concern due to the difficulty and expense of their repair or replacement. The various head-mounted components have been idle in the order of three years, and no data exists which will predict their operation after standing idle for an extended period. When high torque loads were previousiy observed after a single cycle (approximately 100 days) of 
HNF-SD-FF-SSP-056

Rev. 0, Page 36

power operation, these loads were consistently reduced through machine operation. Consequently, a plan will be developed to move these machines through their full range of motion for two purposes. They should be exercised to break up any existing sodium deposits, and to provide operability data to determine the frequency or necessity of periodic exercising.

Operation of the IVHMs can be accomplished with only minor work. All functions of the machines are expected to be exercised, including handling a core component for the purpose of verifying operability of the component identification station.

Exercising the ITs requires the removal of two reactor vessel immersion heaters and an instrumentation assembly installed for secondary sodium drain. The immersion heaters and instrument assembly are installed in the reactor vessel Fuel Transfer Ports (FTPS) and prevent IT movement to the over-core position. They will be removed and stored in a location such as the TACS or the IDS. Regardless of the selected option, future operability of the immersion heaters and instrument assembly will be preserved.

Exercising the CRDMs and the Control Rod Drive Lines requires that the ITs are in their over-core location. All nine Control Rod Drive Lines will be reconnected and operated to fully exercise the equipment.

The operability of the LLFM neutron detectors is a concern, since the detector assemblies have been subjected to a higher than normal temperature environment as a result of securing the LLFM gas cooling system for plant shutdown. LLFM cooling will be restored to provide a cooler environment for the detectors. An evaluation will be made to determine what method, if any, can be used to determine detector operability in the absence of a neutron source.

\subsubsection{Motors and Bearings}

Actions taken for plant shutdown included de-energizing motor space heaters and suspending regular lubrication and bearing rotation programs for systems which were laid up. For standby, all of the motor space heaters will be energized. Each motor heater will be tested to ensure they can safely be energized. If it becomes necessary to energize motors that have not been operated for an extended period, the motor windings will also be tested before operation.

Bearing lubrication and rotation will be selectively resumed, with the emphasis $\mathrm{placed}$ on equipment with high load bearings (Dump Heat Exchanger [DHX] drive trains, diesel generators, LLFM/CRDM cooling system blowers) in which equipment inactivity would be more likely to cause flattening and brinnelling of the bearing surfaces. 


\subsubsection{Preventative Maintenance}

Actions taken for plant shutdown also included the suspension of many preventative maintenance activities on operating equipment, based on the limited time the equipment would remain in service. Selected equipment, such as high voltage transformers and switchgear, and the secondary coolant pumps and their support systems, will have their preventative maintenance reinstated.

\subsubsection{Spare Parts}

Several of the plant's major component spares, such as an Intermediate Heat Exchanger (IHX) shel1 and tube bundle, and the lower half of an IT, were being excessed as an action of plant shutdown. They are presently stored outdoors with minimal protection from the environment. To preserve the components, they will be retrieved and stored in a location more favorable to their preservation. In addition, a review of selected spare parts will be performed to assure adequacy during the standby period.

\subsection{RECONSTITUTE TECHNICAL BASELINE}

\subsubsection{Documentation}

If the FFTF is to continue as a viable option for a future operating mission, the technical information that documents the design basis for the safe and environmentally-sound operation of the reactor must be retained in a secure and easily retrievable condition for the project duration. The intent of this task is to validate the retrievability of specific data and to provide recommendations for the continued maintenance of the necessary database in support of future options for plant operation.

Initial efforts will support the data referenced in the FFTF FSAR. Based upon the findings of this effort, other technical areas will be investigated. Some of the areas under initial consideration are:

1) Core design calculation codes.

2) Safety analysis calculation codes.

3) Natural phenomena hazard design packages and stress reports for buildings and reactor plant systems.

4) Retrievability of ECNs for updating the original as-built design documents.

An evaluation, including recommendations for future actions, will be completed to assure retention of the required technical database. 
HNF-SD-FF-SSP-056

Rev. 0, Page 38

\subsubsection{Configuration Management}

A configuration management implementation $\mathrm{plan}$ will be prepared to meet the $S / R I D$ requirements (Reference 54 ). Design and configuration control practices outlined in WHC-CM-6-1 (Reference 48) will be included in the implementation plan to ensure that a11 participants have access to accurate information. Considering the potential of operating the FFTF for a new mission, a new quality assurance ( $Q A)$ records vault may be required to provide adequate protection for the mission records and documentation.

Documents that must be controlled to ensure accuracy and availability will be identified in the QA Plan. This includes documents that must be controlled as QA records in accordance with WHC-CM-4-2 (Reference 43).

\subsubsection{Personnel}

Evaluation of the technical support for potential restart activities includes determining the availability of skilled technical and operations personnel. Although the FFTF retains an experienced engineering and operations staff, several of the required resources, such as analysts and core physics personnel, are not included in the present plant staffing.

A staffing plan will be developed in parallel with the definition of a potential restart mission. The plan will vary depending on the decisions for items such as:

1) Fuel material and source.

2) Location of fuel manufacture.

3) Location of irradiation target manufacture.

4) Operating cycle schedule requirements.

\subsection{TRAINING}

\subsubsection{FFTF Operating Staff}

\subsubsection{Certification}

Certification of reactor operators and senior reactor operators (chief operators at the FFTF) at Category A reactors, and fissionable material handlers and fissionable material handler supervisors is required according to DOE 5480.20A (Reference 16). Training programs shall consist of a combination of classroom-type and on-the-job training, and include simulator training as it applies to the position.

The FFTF operating personnel will maintain their qualifications and certifications during the standby period. For the positions requiring certification, training is conducted and includes successful completion of comprehensive written examinations, operational evaluations, and oral qualification boards. The individual watch-station requirements dictate which combination of these are applicable to the position. 
Continuing and recertification training programs for certified operations personnel consist of preplanned classroom-type training, on-the-job training, and operational evaluations on a regular and continuing basis. The details for continuing and recertification training for each program are specified by the individual program documentation. During the standby period, the recertification training programs for plant operators, managers and supervisors will continue as they were before the Reference 2 standby directive was received.

Recertification for Fissionable Material Handlers and Managers is required every two years and is accomplished by completing a written examination and the Fuel Handling Evolutions section of the Operator Record Book. The FFTF recertification program for CLEM Operators, BLTC Operators, Plant Refueling Technicians and the Refueling Engineers includes requirements that satisfy the medical requirements, special retraining due to absences and other reasons, annual retraining on emergency procedures, manager's training, and maintaining records as specified in WHC-CM-4-29 (Reference 45).

\subsubsection{Training Accreditation}

While the FFTF is in standby, a revision will be drafted for the FFTF Training Implementation Matrix (TIM), analyzing training program job tasks, and providing lesson plans for the training classes shown below. This preparatory work supports the standards of the Institute of Nuclear Power Operations (INP0) in the event a decision is made to return the FFIF to operation.

1) New Hire Training

2) Operations Technician (OT)

3) Reactor Operator (RO)

4) Operations Engineer/Chief Operator (OE/CO)

5) Shift Operations Manager Training (SOM)

6) Initial \& Continuing Simulator Training \& Certification

\subsubsection{Assumptions}

A11 of the training programs will comply with DOE 5480.20A (Reference 16), meet INP0 standards, and will comply with the new training rule in 10 CFR 830.330 (Reference 30 ). It is anticipated that DOE 5480.18B

(Reference 15) will be canceled, which will obviate the need for the FFTF training programs having to go through an accreditation process.

A training program plan will be developed in parallel with the definition of a potential restart mission. The plan will project when additional training instructors must be available and certified to teach the training programs that will be required if a decision is made to use the FFTF for a new mission.

\subsubsection{FFTF Training Simulator}

\section{Restoration}

Returning the simulator to an operating state will support training in several key areas. Examples include demonstrating pump operations and faults, and reactor shutdown operations including partial loss of flow sequences, loss of 
HNF-SD-FF-SSP-056

Rev. 0 , Page 40

forced flow and sodium leaks. Proper watch standing practices of communications, procedure use, self-verification techniques, team work and leadership are also demonstrated, discussed, and practiced.

Modification Plan

A plan will be prepared to define the FFTF Training Simulator modifications that will be required if a decision is made to return the FFTF to operation. The plan needs to be completed before December 1998 to support a potential decision to return the FFTF to operation. The plan will be based on one of the following scenarios:

Production Reactor If the FFTF is considered and classified as a DOE production reactor, the simulator will need to be a full-scope simulator that meets the requirements contained in ANSI/ANS 3.5 (Reference 32), and Regulatory Guide 1.149 Positions C.5 and C.6 (Reference 34 ) for reactor operator and senior reactor operator training.

Test and Research Reactor If the FFTF is considered and classified as a test and research reactor, the need for a full-scope or part-task simulator shall be based on an evaluation conducted by the operating organization.

\subsubsection{EDS Operating Staff}

Requalification and training related to emergency procedures, abnormal procedures, and equipment changes that may impact operations is completed for Examination and Decontamination Services (EDS) personnel annually. Their requalification consists of required reading and an oral evaluation by Lead Engineers.

A11 EDS personnel participate in the Biennial Requalification Program. This program requires attendance at lectures, completion of selected performance items (as delineated in the Continuing Training Record Book), required reading, on the job evaluations, written and oral evaluations and Fissionable Material Handler recertification requirements.

\subsubsection{FFTF Maintenance Staff}

The FFTF Maintenance Training Program provides systematic, performance based training by which an assigned craftsman completes the training necessary for safe and efficient operations in the FFTF, FMEF, and MASF.

Retraining is required biennially for all craftsmen who perform work on essential equipment and systems.

\subsubsection{Technical Staff}

The FFTF Technical Support Staff Training Program documents the process used for integrating the requirements of DOE 5480.20A (Reference 16) and 400 Area training plans. This program provides systematic, performance based training for the FFTF technical support staff and management responsible for the safe and efficient operation of the FFTF, FMEF, and MASF. 
Continuing training is required for personnel who perform functions associated with safety-related structures, systems, and components identified in the FFTF FSAR. This training is designed to ensure that the technical staff, including managers, improve their skills and remain cognizant of plant and procedure modifications, changes to requirements, lessons learned from industry and FFTF operating experience. This training is designed to review important knowledge areas, even if infrequently used, and to increase the depth of job-related skills and knowledge.

Continuing training for the FFTF cognizant engineers is provided by the Person-in-Charge (PIC), and the Unresolved Safety Question Evaluator (USQE) Continuing Training Programs. The PIC and USQE Continuing Training programs provide periodic formal classroom training on the subjects detailed above.

\subsection{ENGINEERING STUDIES}

A limited number of equipment vulnerability studies followed by selected evaluation of plant or system enhancements will be conducted during the standby period subject to funding constraints. Due to the complexity and uniqueness of much of the fuel handling equipment and systems, aging problems, and that the majority of required work on these components involves intensive planning due to radioactive contamination control and personnel protection requirements, repairs are typically lengthy and difficult. Most of the fuel handling equipment (e.g., CLEM) are one-of-a-kind components where failure of one impacts the entire component handling process. Because the potential impacts can be substantial to either the standby period, restart, or deactivation schedules, certain enhancements may be selected for further development. Other plant systems or components may be selected for study depending on potential impacts and funding availability.

\subsection{ASME CODE PRESSURE BOUNDARY AND SEISMIC INTEGRITY}

The American Society of Mechanical Engineers (ASME) Code pressure boundary and Seismic Category 1 integrity will be maintained during standby.

Because the reactor has been shutdown for an extended period, there is no longer any significant radioactive gas species present. For this reason, surveillance is no longer required on a number of reactor cover gas containing components. For example, there is a group of ASME-coded check valves known as "refueling check valves" which prevent reactor cover gas leakage in the event non-code inert gas supply lines are damaged. These gas pressure boundary components are no longer tested to the code. In addition, the temporary components inserted through the reactor head into the cover gas space to support previously planned sodium drain activities (e.g., two immersion heaters and one instrument assembly) are not designed to ASME Section III requirements. Gas system components, such as relief valves, which are important to the sodium pressure boundary, will be maintained to code requirements during standby.

Prior to September 1994, the Technical Specifications contained requirements for leak-testing the code boundaries for the Heat Transport System (HTS), reactor head, and the Reactor Containment Building. In September 1994, these requirements were deleted in conjunction with the Technical Specifications 
Reduction Project, since the configuration and conditions were such that no credible event could affect public health and safety. Although the leak-testing requirements are no longer in effect, the Reactor Containment Building is being maintained as a fire barrier with certain ASME surveillance procedures continuing to be performed in lieu of fire barrier inspections.

Limited surveillance and in-service inspections will be continued during the FFTF standby period. These inspections will follow the guidelines of ASME Section XI, Division 3, Rules for In-service Inspection and Testing of Liquid Metal Cooled Plants. Protection of the HTS boundary will be assured by continued testing of the cover gas pressure relief valves as well as operability testing of the Seismic 1 Active HTS boundary valves. Seismic integrity will be maintained by continuing the existing snubber surveillance program. Surveillance of the HTS boundary via leak detection has been reduced to the reactor vessel and sodium tank level sensors, contact detectors, and smoke detectors. On-line aerosol leak detection has been deferred since virtually no sodium aerosols are generated at the standby sodium temperature of $400^{\circ} \mathrm{F}$. Deferral of surveillances such as visual inspections of primary HTS piping welds to Intermediate Heat Exchanger and pump nozzles, reactor support arm welds, and on-line aerosol leak detection is permitted by ASME Section XI, Division 3, Section IMA-2430(e), as stated below:

"For plants that are out of service continuously for 6 months or more, the inspection interval during which the outage occurred may be extended for a period equivalent to the outage"

Deferral of the surveillances during the FFTF standby period is justified by the fact that no weld anomalies (cracks or defects) were found during weld inspection surveillances over 10 years of operation (April 1982 - Apri1 1992). Primary piping surveillances were completed for a11 three HTS loops in December 1993. Only minimal snubber movements have been observed throughout the surveillances conducted over the 10-year surveillance period indicating piping geometry has been maintained.

However, in addition to the existing snubber surveillance program, a random sampling of snubbers will be tested in the primary HTS to verify the lubricant has not degraded from a radiation and temperature environment during 10 years of reactor operation. Sampling will also include small bore snubbers that may be susceptible to lockup from dust introduced into the primary cells from minor surface oxidation of the carbon steel cell cooling system piping.

Until the fuel was removed from the reactor during the previous transition period, modifications and repairs to the sodium boundary were controlled via ASME Section XI Repair Programs, involving the DOE and an authorized third party nuclear inspector, to assure that the ASME code boundary integrity was maintained. Future modifications and repairs during the standby period will continue to utilize the ASME Section XI Repair Program process to preserve the FFTF HTS boundary for operation. A11 work performed on the FFTF HTS boundary has met the requirements of ASME Section XI.

Modifications completed in support of the prior planned sodium drain process were designed and installed per approved work packages typically used for nonnuclear ASME B31.1 piping systems. This includes the drain piping between the 
FFTF, the FSF, and the new SSF. ASME B31.1 was also utilized for piping installed for the original FFTF sodium fill process. Application of ASME B31.1 requirements (instead of ASME Section III for the original design) is deemed appropriate considering the separation of these drain piping systems from the FFTF via valves, short term use, and generally reduced pressure and temperature conditions associated with the drain process. Safety Class 2 is the highest classification applied to the approved design of the SSF. The SSF is being maintained in an interim layup condition at ambient temperature to eventually receive nearly 260,000 gallons of the FFTF and the FSF sodium at some time in the future.

\subsection{PLANT SYSTEMS}

The current configuration of the various FFTF plant systems fall into a spectrum of being fully operable to being fully laid up, depending upon where the individual system, or components of that system, fit into the transition to shutdown. The majority of plant systems, whether they are operable or laid up, will remain in their current configuration. The current system

configurations are described in Appendix B.

During the standby period, some system configuration changes are necessary to prevent system degradation. These are also described in Appendix B. Section 6.2, Plant Preservation, develops the strategy used to identify these changes.

\subsection{MAINTENANCE AND STORAGE FACILITY}

The Maintenance and Storage Facility (MASF) is located in the 400 Area approximately 500 feet north of the FFTF complex and west of the railroad track serving the FFTF Reactor Service and Reactor Containment Buildings. It was designed as a multipurpose service center to support the specialized maintenance and storage requirements of the 400 Area facilities. The MASF will continue to provide maintenance services for the FFTF during the standby phase. The facility may be used for testing equipment associated with the shearing of long FFTF reactor test assemblies.

Current plans for the MASF include support of several long term commitments to the Hanford Tank Waste Remediation System (TWRS) organization for performance testing of Tank Farm mixer pumps. No other suitable facility on the Hanford Site is available to provide this support.

\subsection{FUELS AND MATERIALS EXAMINATION FACILITY}

The FMEF is located in the 400 Area approximately 750 feet west of the FFTF. The FMEF was originally constructed to support the Breeder Reactor Program, which was canceled in the $1980^{\prime} \mathrm{s}$. The facility is ideally suited to provide fuel and target assemblies to support new missions for the FFTF.

Current plans are to maintain the FMEF in a standby condition to support the direction provided by Reference 1 and Reference 2. In the meantime, the FMEF will continue to provide support to other projects on the Hanford Site such as the TWRS. 
HNF-SD-FF-SSP-056

Rev. 0, Page 44

This page intentionally left blank. 


\subsection{NEN FFTF INITIATIVES}

This section defines new initiatives that will be managed and conducted by the FFTF Project. The completion of these activities will provide information to help the DOE reach a decision regarding the potential restart of the FFTF. This will also reduce costs and save time in the event a decision is made to restart the FFTF. These activities will be prioritized and completed as staff and funding become available.

In the event additional initiatives are identified during the standby period, they will be evaluated and assigned to the appropriate organization by the SPO.

\subsection{ENVIRONMENTAL STUDIES}

The January 17, 1997 Memorandum for the Secretary of Energy (Reference 1) approved the following recommendation:

"Maintain the Fast Flux Test Facility in the hot standby condition and conduct safety and environmental analyses that could support nuclear safety or National Environmental Policy Act documents, if required at a later time. Review the feasibility of using Fast Flux Test Facility for medical isotope production."

In the area of environmental studies, there is a substantial amount of data that can be gathered to support future NEPA documentation. This data consists of information on the various proposed tritium production activities including: FMEF fuel and target fabrication, FFTF operations such as irradiated fuel and target handling, and medical isotope production. Anticipated routine releases, bounding accident analyses, worker exposures, and data on topics such as waste generation and disposal, resource impacts, etc., would be prepared to support future NEPA documentation. Completing these studies will assist the DOE in deciding whether or not the FFTF will be used for a new mission.

\subsection{SAFETY ANALYSES}

Evaluation of the safety of the new core design and preparation of a revision for the FSAR will be a major task required for restart. During the standby period, the scope will be defined and preparations made for initiation of the detailed programs if a decision is made for returning the FFTF to an operational state. Additionally, selected bounding analyses will be conducted for input to the environmental analyses discussed in Section 7.1.

\subsubsection{Detailed Plan Development}

This initial task is a planning effort to identify the scope of work required for preparation of the revised FSAR and the resources required to complete the work. The extent of the review process for authorization of a return to reactor operation is not clear and needs to be defined as an initial step in this evaluation. The analyses required to support the revised core configurations and the resources required to conduct the analyses will be 
HNF-SD-FF-SSP-056

Rev. 0, Page 46

defined, and preliminary cost estimates and schedules prepared to scope the total effort.

\subsubsection{Create FSAR Reference Library}

The current FSAR references comprise an extensive list of documents and reports. A complete reference listing will be developed and access to each document will be assured. Completion of this task will assure that the referenced documents are available in support of the FSAR.

\subsubsection{Perform Selected FSAR Safety Analyses}

The scoping analyses performed in the core design for potential tritium production have not revealed any prohibitive safety issues. The inclusion of a large number of interior region targets does increase the linear heat rate and significantly changes the reactivity feedbacks of the core. More detailed analyses will be conducted to confirm these conclusions and to provide bounding case accident analyses for input to environmental evaluations. This program requires the support of core design analyses and re-establishment of the capability to perform accident analyses. The early initiation of these efforts will reduce the technical and financial risks in the decision on future potential FFTF operations.

\subsubsection{Sodium Spray Fire Models}

Selected sodium leak analyses will be evaluated to facilitate DOE's decision in December 1998 for the future of the FFTF.

\subsubsection{FSAR Revision}

The FSAR will be revised as an initial action following a decision to return the FFTF to operation for a new mission. This revision will comply with the requirements in DOE 5480.23 (Reference 18), and update the document for justification of the authorization to return the FFTF to operation. Completion of the above tasks during the standby period will provide an initial database for this potentially critical path task.

\subsection{NATURAL PHENOMENA HAZARD AND LIFETIME EVALUATIONS}

A library of existing design reports for buildings and components will be established. The natural phenomena hazard (seismic, wind, tornado, etc.) loading increases, and lifetime extension to 30 years will be reviewed to identify any technical concerns related to new requirements. A plan will be prepared to resolve any concerns that may be found during the review. 


\subsection{INFORMATION TO THE PUBLIC AND STAKEHOLDERS}

\subsection{INTRODUCTION}

Information will be provided to the public and stakeholders during the standby phase. If the Secretary of Energy decides to include the FFTF in the tritium and medical isotope production strategy, formal public participation will begin as part of the NEPA and the State of Washington Environmental Policy Act (SEPA) processes. Again, this decision is expected by December 1998.

The Project Director will be responsible for providing information to the Richland Operations Office (RL) Office of Public Affairs, who will provide information to the public.

\subsection{OBJECTIVE}

Accurate and timely information regarding possible FFTF/FMEF missions will be given to stakeholders, regulators, tribes, and the Hanford Advisory Board to enhance mutual understanding. Through plant tours, briefings and written information, by responding to comments and questions, the DOE will help the public understand the technical and legal framework within which the DOE will make its decision regarding using the FFTF for a future mission. The DOE, in turn, can better understand the effects of its proposed actions on the local community and the environment by listening to those affected by and interested in the project.

\subsection{TPA MILESTONES}

The January 1997 decision to place the FFTF in standby necessitates the deferral of some TPA milestones (Reference 35) and (Reference 36).

Negotiations in 1997 to defer the milestones impacted by the standby decision will include a 45-day public involvement period. 
HNF-SD-FF-SSP-056

Rev. 0, Page 48

This page intentionally left blank. 


\subsection{SAFEGUARDS AND SECURITY}

The safeguards and security requirements will remain in full compliance with the approved FFTF S/RID (Reference 54). The storage and inventory requirements for Category I quantities of SNM stored in the FFTF IDS vessel will continue to be based on two approved DOE Order deviations (Reference 8 and Reference 9). The 400 Area ISA Security Plan (Reference 7) remains in effect.

A plan will be prepared for the 400 Area security upgrades that will be required if a decision is made to use the FFTF and the FMEF for a new mission. 
HNF-SD-FF-SSP-056

Rev. 0, Page 50

This page intentionally left blank. 


\subsection{KEY ASSUMPTIONS, ISSUES AND ACTION ITEMS}

\subsection{KEY ASSUMPTIONS}

The Secretary of Energy approved a Memorandum of Decision (MOD) on January 17, 1997 (Reference 1) that the FFTF be maintained in a standby condition to permit the DOE to make a decision on whether the facility should play a future role in the DOE dual track tritium production strategy. This Plan is in response to the MOD with the following assumptions and action items :

1) The DOE decision on the future role of the FFTF will be made in parallel with the intended December 1998 decision on the selection of the primary, long-term source of tritium.

2) The previous DOE directives (Reference 3 and Reference 4) regarding the shutdown of the FFTF are deferred by the DOE decision to maintain FFTF in standby (Reference 1).

3) The technical objectives during the standby period are:

- To maintain the facility in a standby mode complying with the appropriate federal, state, and local laws and regulations. The FFTF activities conducted during the standby period will preserve the capability for timely restart of the FFTF and the FMEF, if so directed by the DOE.

- To continue scheduled deactivation activities consistent with the standby mode, such as the cleaning and storing of SNF, deactivating sodium legacy facilities, and deactivating the 309 Building.

- To conduct safety and environmental analyses that could support nuclear safety or NEPA documents, if these are required at a later time.

- To review the economic and technical feasibility of using the FFTF to produce medical isotopes.

4) The DOE will fully support the project by providing required funding and timely reviews of appropriate documentation. Any funding shortfalls will delay work and result in higher costs.

5) Experienced staff will be available as needed throughout the standby period to support the schedule.

6) No activities will be conducted that would preclude restart of the facility.

7) Independent safety oversight will be provided by the FDH Facility Evaluation Board. 
8) Environmental oversight will be provided by the U.S. Environmental Protection Agency (EPA), the Washington State Department of Ecology (Ecology), the Washington State Department of Health (DOH) and the DOE.

9) No additional Readiness Reviews (RR) or Readiness Assessments (RA) are planned during the standby period.

10) Management of the FFTF during the standby period will continue to follow the guidance in the DOE 4700.1 Project Management System (Reference 11) and the WHC-CM-2-5 Management Control System (Reference 42).

11) In the event a decision is made to use the FFTF and the supporting 400 Area facilities for a new mission, it is expected that a new project plan will be prepared consistent with the "graded" project management approach of DOE 0430.1 .

12) During the standby period, the FSAR, including Chapter 17, Technical Specifications, will continue as the Authorization Basis to support facility operations.

13) Implementation of the DOE 0rders will continue according to the FFTF S/RID (Reference 54). The S/RID requirements are sufficient to maintain worker and public safety and health, and to protect the environment during the standby period.

14) All preliminary analyses or engineering studies performed to support a future mission will be conducted according to the appropriate DOE Orders and standards. If it is decided that the FFTF will be used for a new mission, the FFTF S/RID will be revised to assure compliance with the applicable orders and regulations.

15) Transition of the controlled manuals, and internal procedures applicable to the FFTF Project; such as the WHC-CM-4-43 Emergency Management Procedures (Reference 47) and the FFTF Building Emergency P1an (Reference 49) to a new internal FFTF procedure system will take place on or before October 1997.

16) Only Category IVE SNM that has been evaluated and determined to be of no use to a future mission will be washed and stored during the standby period.

17) Washing to remove sodium from the slightly and moderately-radioactive Category IC, IIC and IIID SNM as defined per DOE 5633.3B (Reference 24), and described in the FFTF Stabilization Project Plan (Reference 51), will be placed on hold during the standby period pending future mission direction.

18) Washing to remove sodium from the unirradiated Category IC SNM as defined in DOE 5633.3B (Reference 24), and described in the FFTF Stabilization Project Plan (Reference 51), will be placed on hold during the standby period pending future mission direction. 
19) The program for disposition of electrical transformer polychlorinated biphenyl (PCB-containing) cooling oil will be placed on hold until a decision is reached on the path forward for the FFTF. To date, five of 19 transformers have been removed from the FFTF and sat isfactorily dispositioned.

20) Training will comply with DOE $5480.20 \mathrm{~A}$ (Reference 16), meet INP0 standards, and comply with the new training rule in 10 CFR 830.330 (Reference 30). It is anticipated that DOE 5480.18B (Reference 15) wiTl be canceled, which will obviate the need for the FFTF training programs having to go through an accreditation process.

21) Limited surveillance and in-service inspections will be continued during the FFTF standby period. These inspections will follow the guidelines of ASME Section XI, Division 3. Deferral of surveillances such as visual inspections of primary HTS piping welds to Intermediate Heat Exchanger and pump nozzles, reactor support arm welds, and on-line aerosol leak detection is permitted by ASME Section XI, Division 3, Section IMA-2430(e).

\subsection{ISSUES AND ACTION ITEMS}

The following action items are related to the standby period and the decision on possible future missions for the FFTF. Items that require resolution during the standby period are identified.

1) The Fifth Amendment to the Hanford Federal Facility Agreement and Consent Order (Tri-Party Agreement) was issued in July 1995 (Reference 35) and subsequently revised in December 1996 (Reference 36). Established within this agreement are major and interim milestones and target dates addressing the transition of the FFTF to a safe deactivated state. The standby period will impact the achievement of milestone dates in the agreement.

ACTION: Dialogue with the regulators must be initiated to explain the impacts to the current agreement and request a deferral. Milestones would be revised or established depending upon decisions related to the future of the FFTF.

2) The disposition of the IEM Cell Mockup, or training facility, must be determined to support the deactivation of the 309 Building.

ACTION: The FFTF must determine an action plan for the facility. The funding and implementation of this plan must be on a schedule which is consistent with the final deactivation of the 309 Building. 
3) Develop a conceptual core design for irradiation of tritium producing targets in the quantities necessary to achieve potential mission objectives. This is also required to support safety and environmental analyses.

ACTION: Develop a conceptual core design and initiate analysis of reactor core configurations to support bounding case safety and environmental analyses.

4) The current fuel design, and all fuel currently available for continued operations, provides gas tagging of fuel pins to facilitate the location of failed fuel cladding. It has been past policy not to operate the plant with failed fuel. However, the plant instrumentation and support organizations necessary to monitor and detect the tag gas are not currently available.

The alternatives to be considered are:

- Continue the policy of not operating with failed fuel, and continue to provide gas tagging capability.

- Continue the policy of not operating with failed fuel, and seek other means of locating failed fuel.

- Plan to continue operation in the event of fuel failure, and evaluate means of dealing with resultant coolant and cover gas contamination.

ACTION: An early decision is required among these alternatives in order to establish conceptual design requirements for new fuel, and to establish plant equipment requirements. A cost benefit analys is that considers the safety and environmental requirements is needed.

5) To achieve and sustain the intended plant capacity factor, it may be necessary to improve the schedules for handling target assemblies into and out of the reactor.

ACTION: An early evaluation of possible alternatives is needed in order to establish conceptual design and equipment requirements.

6) Current operational concepts for tritium production contemplate replacement of all radial reflectors in the reactor core with tritium-producing target assemblies. The effect of this change in core configuration has not been analyzed, but the probability exists that unacceptable masking of neutron flux at the current location of the power range detectors may result.

ACTION: An early analysis and evaluation is needed to assure satisfactory power range neutron flux monitoring. 
7) Several alternative sources for the fabrication and assembly of irradiation targets are possible and include:

- Fabricate pins and completed assemblies in the FMEF.

- Perform assembly in the FMEF, using commercially-supplied pins.

- Qualified commercial suppliers of pins and/or complete assemblies, fabricated to the FFTF specifications.

- Fabricate pins and/or completed assemblies in another site facility using contractor staff.

In any of these alternatives, final inspection, acceptance, and storage would occur in the FMEF.

ACTION: An early decision on the plan for target fabrication and assembly will be needed in order to support the FMEF design and configuration decisions.

8) Qualified casks suitable for offsite shipment of target assemblies (or pins) irradiated in the FFTF may not be available.

ACTION: Determine status of plans for irradiated target shipping and correlate with the availability of shipping casks.

9) An engineering study in 1989 addressed the additional capabilities and equipment requirements to provide "full function" capabilities on the FFTF simulator equivalent to those used on commercial power reactor simulators. This added capability may or may not be needed to support resumption of reactor operations.

ACTION: Evaluate the requirements and extent of upgrades required for the FFTF training simulator. Prepare a position paper for management review and approval. 
HNF-SD-FF-SSP-056

Rev. 0, Page 56

This page intentionally left blank. 


\subsection{REFERENCES}

1. Memorandum

2. Letter

3. Memorandum

4. Letter

5. Letter

6. Letter

7. Letter

8. Letter
Eldon W. Joersz, Major General, USAF, Principal Deputy Assistant Secretary for Military Application, Tritium Project Office, Memorandum for the Secretary, Department of Energy, "ACTION: Decision on maintaining the Fast Flux Test Facility in a hot standby capacity to permit the Department to make a decision by 1998 on whether the facility should play a future role in the Department of Energy's tritium production strategy, if appropriate." (Approved by the Secretary of Energy, January $17,1997$.

S. A. Sieracki, Contracting officer, RL, to H. J. Hatch, President, FDH, "Contract No. DE-1AC0696RL13200: Advanced Reactors Transition (ART) Program Direction," 97-TPD-003, January 18, 1997.

Daniel A. Dreyfus, Acting Director, Office of Nuclear Energy, to John D. Wagoner, Manager, Richland Operations Office, "Commence Fast Flux Test Facility Shutdown (FFTF) Activities," December 15, 1993.

J. D. Wagoner, RL, to T. M. Anderson, WHC, "Fast Flux Test Facility (FFTF) Shutdown," OTD:OAF, December 15, 1993.

Sally A. Sieracki, RL, to H. J. Hatch, FDH, "Contract No. DE-AC06-96RL13200: Directed Change to the Advanced Reactors Transition Baseline," 96-1TPD-225, October 31, 1996.

R. J. Bliss and J. C. Fulton, WHC, to C. A. Hansen and L. L. Piper, RL, "Fast Flux Test Facility Position on Sodium Bonded Fuel Shipments to Argonne National Laboratory-West," 9650926, March 1, 1996, (White Paper attached, "Impacts of Delaying Shipment of the Sodium-Bonded Fuel to the Idaho National Engineering Laboratory and Interim Disposition Options").

E. F. Loika, WHC, to J. E. Mecca, RL, "Security Plan for the 400 Area Interim Storage Area, " 9555585, October 16, 1995.

J. L. Spracklen, RL, to President, WHC, "Approval of WHC Deviation to DOE Order 5633.3B, 'Control and Accountability of Nuclear Materials,' Reduce the Inventory Frequency of the Fast Flux Test Facility (FFTF) Category IC Driver Fuel Assemblies Stored in the Interim Decay Storage (IDS) Vessel,"

February 1, 1995. 
HNF-SD-FF-SSP-056

Rev. 0 , Page 58

9. Letter

10. DOE 0430.1

11. DOE 4700.1

12. DOE 5480.4

13. DOE 5480.7A

14. DOE 5480.10

15. DOE $5480.18 \mathrm{~B}$

16. DOE $5480.20 \mathrm{~A}$

17. DOE 5480.22

18. DOE 5480.23

19. DOE 5480.28

20. DOE 5480.30

21. DOE 5480.31

22. RLID 5480.31

23. DOE 5483.1A
J. E. Mecca, RL, to President, WHC, "Approval of WHC91-002 REV 1, Continued Storage of Category IC Special Nuclear Material (SNM) in the Fast Flux Test Facility (FFTF) that has no Material Access Area," February 1, 1994.

Life-Cycle Asset Management, U.S. Department of Energy, Washington, D.C.

Project Management System, U.S. Department of Energy, Washington, D.C.

Environmental Protection, Safety, and Health

Protection Standards, U.S. Department of Energy, Washington, D.C.

Fire Protection, U.S. Department of Energy, Washington, D.C.

Contractor Industrial Hygiene Program, U.S. Department of Energy, Washington, D.C.

Nuclear Facility Training Accreditation Program, U.S. Department of Energy, Washington D. C.

Personnel Selection, Qualification, and Training Requirements for DOE Nuclear Facilities, U.S. Department of Energy, Washington D. C.

Technical Safety Requirements, U.S. Department of Energy, Washington D. C.

Nuclear Safety Analysis Reports, U.S. Department of Energy, Washington D. C.

Natural Phenomena Hazards Mitigation, U.S. Department of Energy, Washington D. C.

Nuclear Reactor Safety Design Criteria, U.S. Department of Energy, Washington D. C.

Startup and Restart of Nuclear Facilities, U.S. Department of Energy, Washington D. C.

Startup and Restart of Facilities Operational Readiness Review and Readiness Assessments, U.S. Department of Energy, Richland Operations Office, Richland, Washington.

Occupational Safety and Health Program for DOE Contractor Employees at Government-Owned Contractoroperated Facilities, U.S. Department of Energy, Washington, D.C. 
24. DOE $5633.3 \mathrm{~B}$

25. DOE $5700.6 \mathrm{C}$

26. DOE/EA-0993

27. DOE/RL-93-75

28. DOE/RL-94-02

29. 10 CFR 830.120

30. 10 CFR 830.330

31. 10 CFR 835

32. ANSI/ANS 3.5

33. NFPA 101

34. Nuclear Regulatory Guide 1.149

35. No Doc Number

36. No Doc Number

37. No Doc Number

38. HEDL-TI-75001

39. HSCRCM-1
Control and Accountability of Nuclear Materials, U.S. Department of Energy, Washington D. C.

Quality Assurance, U.S. Department of Energy, Washington $D$. C.

Environmental Assessment, "Shutdown of Fast Flux Test Facility, Hanford Site," includes Finding of No Significant Impact, May 1995, U.S. Department of Energy, Richland, Washington.

Hanford Facility Contingency P1an

Hanford Emergency Response Plan

Quality Assurance Requirements, U.S. Department of Energy, Washington D. C.

Training and Certification, Code of Federal

Regulations (Pending release.)

Occupational Radiation Protection

Nuclear Power Plant Simulators for Use in Operator Training

Life Safety Code, National Fire Protection Association Standard 101.

Nuclear Power Plant Simulation Facilities for Use in Operator Licensing Examinations, Regulatory Guide Positions C.5 and C.6, Revision 1, April 1987.

Ecology, EPA, and DOE, July 1995, "Tentative Agreement on Facility Transition, "Hanford Federal Facility Agreement and Consent Order, as amended, Washington State Department of Ecology, U.S. Environmental Protection Agency, and U.S. Department of Energy, 01 ympia, Washington. [Tri-Party Agreement]

Ecology, EPA, and DOE, "Tri-Party Agreement M-33/M-90 Change Package and other Documents, "Hanford Federal Facility Agreement and Consent Order, December 31, 1996.

Public Service Co. of Colorado v. Batt, No. CV 91-0035-S-EJL (District of Idaho) and United States $v$. Batt, No. CV-91-0054-S-EJL (District of Idaho). [Consent Order, October 27, 1995].

Fast Flux Test Facility Final Safety Analys is Report. Hanford Site Radiological Control Manual 
HNF-SD-FF-SSP-056

Rev. 0, Page 60

40. $W H C-C M-1-10$

41. WHC-CM-1-11

42. WHC-CM-2-5

43. WHC-CM-4-2

44. WHC-CM-4-27

45. $W H C-C M-4-29$

46. WHC-CM-4-41

47. WHC-CM-4-43

48. $W H C-C M-6-1$

49. WHC-IP-0263-FFTF
Safety Manual

Industrial Hygiene Manua]

Management Control System

Quality Assurance Manual

Radiological Control Practices and Procedures

Nuclear Criticality Safety Manual

Fire Protection Program Manual

Emergency Management Procedures [Transition WHC-CM-4-43 to a new internal FFIF procedure system will take place on or before 0ctober 1997.]

Standard Engineering Practices

Building Emergency Plan for FFTF Property Protection Area [Transition of WHC-IP-0263-FFTF to a new internal FFTF procedure system, will take place on or before October 1997.]

50. WHC-SD-SP-SSP-001 309 Building Transition Plan, Revision 1.

51. WHC-SD-FF-SSP-004 Fast Flux Test Facility Stabilization Project Plan, Revision 3, B\&W Hanford Company, November 15, 1996.

52. WHC-SD-FF-SSP-050 Advanced Reactors Transition Program Resource Loaded Schedule, Revision 3, September 30, 1996, Westinghouse Hanford Company, Richland, Washington.

53. WHC-SD-FF-SSP-052 Advanced Reactors Transition Fiscal Year 1997 MultiYear Work Plan WBS 7.3, Revision 2, September 25, 1996.

54. WHC-SD-MP-SRID-006 Fast Flux Test Facility Standards Requirements Identification Document, Revision 0, January 1997. 
HNF-SD-FF-SSP-056

Rev. 0, Page A-1

\section{APPENDIX A}

\section{FFTF PROJECT MANAGEMENT}


HNF-SD-FF-SSP-056

Rev. 0, Page A-2

This page intentionally left blank. 
HNF-SD-FF-SSP-056

Rev. 0, Page A-3

APPENDIX A

FAST FLUX TEST FACILITY PROJECT MANAGEMENT

Table of Contents

1.0 INTRODUCTION ......................... 5

2.0 SCOPE AND OBJECTIVES . . . . . . . . . . . . . . . . . 7

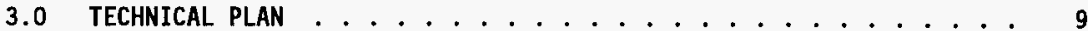

3.1 TECHNICAL APPROACH ................... 9

3.2 WORK BREAKDOWN STRUCTURE AND RESOURCE LOADED SCHEDULE . . . . 9

4.0 RISK ASSESSMENT . . . . . . . . . . . . . . . . . 11

4.1 TECHNICAL . . . . . . . . . . . . . . . . 11

4.2 SCHEDULE . . . . . . . . . . . . . . . . . . . . 11

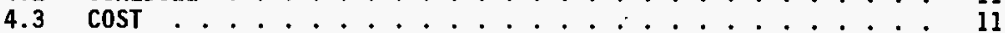

4.4 ENVIRONMENTAL, HEALth ANd SAFETY . . . . . . . . . . . . . . . . 11

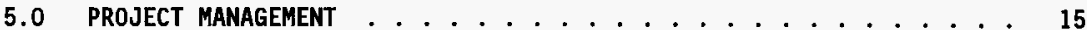

5.1 MANAGEMENT STRATEGY ................... 15

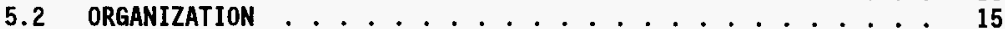

5.3 MANAGEMENT CONTROL SYSTEM ................. 15

5.3.1 Introduction . . . . . . . . . . . . . . . . 15

5.3.2 Scope Baseline Management . . . . . . . . . . . 16

5.3.3 Cost Basel ine Management .............. 16

5.3.3.1 Cost Estimate Reviews ............ 16

5.3.3.2 Cost Performance Monitoring . . . . . . . . 17

5.3.4 Schedule Basel ine Management . . . . . . . . . . 18

5.3.5 Performance Reporting ............... 18

5.3.5.1 Performance Reports . . . . . . . . . . . 18

5.3.5.2 Report Distribution ............. 18

5.3.5.3 Review Meetings ............. 18

5.4 BUDGET, COST AND SCHEDULE PERFORMANCE MEASUREMENT . . . . . . . 19

6.0 BASELINE CHANGE CONTROL . . . . . . . . . . . . . . . . 21

6.1 CHANGE CONTROL BOARD .................... 21

6.2 CHANGE CONTROL BOARD OPERATION ............... 21

6.2.1 FFTF Change Control Board Chairman . . . . . . . . . 21

6.2.2 FFTF Change Control Board Secretary . . . . . . . . . 22

6.2 .3 Consultants . . . . . . . . . . . . . 22

6.2.4 Change Control Board Meetings ............. 22

6.2.5 Baseline Change Request Priority . . . . . . . . . . . 22

6.3 BASELINE CHANGE REQUEST .................... 23

6.3.1 Change Classifications . . . . . . . . . . . . 24

6.3.2 Change Request Review and Approval . . . . . . . . . 26

6.3.3 Change Request Distribution ........... 28 
HNF-SD-FF-SSP-056

Rev. 0, Page A-4

Table of Contents (continued)

7.0 CHARTER . . . . . . . . . . . . . . . . . . 29

7.1 INTRODUCTION ................... 29

7.2 MANAGEMENT TEAM ................... 29

7.2.1 Department of Energy ............. 29

7.2.2 Richland Operations office

Transition Program Division (RL) . . . . . . . . 29

7.2.3 FFTF Standby Project office . . . . . . . . . . 29

7.2 .4 FFTF Project ..................... 29

7.2 .5 FFTF Transition Project office ................. 29

7.2.6 Support Functions ............. 30

7.3 FFTF TRANSITION PROJECT OFFICE ............. 30

7.3.1 Team Building .............. 30

7.3.2 Planning and Basel ine Schedule Development ..... 30

7.3.3 Change Control .............. 31

7.3.4 Budget and Cost Estimates ............ 31

7.3 .5 Technology ............... . . 31

7.3.6 Project Reports and Records .......... 31

8.0 REFERENCES ........................ 33

\section{List of Figures}

Figure 5-1 Performance Analysis and Reporting Process ........ 20

List of Tables

Table 4-1 Risk Identification, Assessment \& Response . . . . . . . . 12

Table 6-1 Basel ine Change $\mathrm{Cl}$ asses ............... 25

Table 6-2 Baseline Change Request Review and Approval . . . . . . . 27

Table 6-3 Baseline Change Request Distribution . . . . . . . . 28 


\section{APPENDIX A}

\section{FAST FLUX TEST FACILITY PROJECT MANAGEMENT}

\subsection{INTRODUCTION}

This appendix describes the approach that will be used by the FFTF project team to effectively manage the scope, cost and schedule baselines defined in Section 2.0 of the FFTF Standby Plan. This is based upon the guidance in the DOE 4700.1 Project Management System procedure (Reference 1) and the WHCCM-2-5 Management Control System procedure (MCS) (Reference 6).

DOE 4700.1 is referenced throughout Appendix $A$. It is anticipated that DOE 4700.1 will be superseded by DOE 0 430.1, Life-Cycle Asset Management (Reference 2) during FY 1997. The management approach during the standby period will continue to be based upon DOE 4700.1 until formal direction is received to implement DOE 0430.1 .

The current planning is based on maintaining the FFTF in standby according to Reference 9 and Reference 10 . If it is decided that the FFTF and the supporting 400 Area facilities will be used for another purpose, a project plan will be prepared consistent with the "graded" project management approach allowed by DOE 0430.1 (Reference 2).

The following documents will be used in concert with each other to manage the work activities.

- WHC-SD-FF-SSP-052

- WHC-SD-FF-SSP-050

- HNF-SD-FF-SSP-056
Advanced Reactors Transition Fiscal Year Multi-Year Work Plan

FFTF Resource Loaded Schedule

FFTF Standby Plan 
HNF-SD-FF-SSP-056

Rev. 0, Page A-6

This page intentionally left blank. 
HNF-SD-FF-SSP-056

Rev. 0, Page A-7

\subsection{SCOPE AND OBJECTIVES}

The primary objective is to maintain the condition of the plant systems, equipment and personnel to preserve the option for plant restart within three and one-half years of a decision to restart, while continuing deactivation work which is consistent with the standby mode. No construction projects are needed to support the FFTF during the standby period.

The activities, schedule and cost objectives are explained in more detail in Section 2.0 of the FFTF Standby Plan. The FFTF RLS (Reference 7) will be revised to incorporate the Reference 9 direction to maintain the FFTF in standby. 
HNF-SD-FF-SSP-056

Rev. 0, Page A-8

This page intentionally left blank. 


\subsection{TECHNICAL PLAN}

\subsection{TECHNICAL APPROACH}

The technical approach is based upon using existing nuclear and liquid metal process technology to maintain the FFTF in an industrially and radiologically safe condition during the standby period.

The activities will be managed against Fluor Daniel Hanford (FDH) approved scope, schedule and cost baselines. The technical expertise of the FFTF staff and other contracted resources will be used whenever practical to minimize costs. Offsite technical support may be used whenever their services are cost effective.

\subsection{WORK BREAKDOWN STRUCTURE AND RESOURCE LOADED SCHEDULE}

The purpose and objectives for maintaining the FFTF in standby are described in the FFTF Standby Plan.

The Work Breakdown Structure (WBS) is provided by Figure 1 in the Plan. The WBS is based upon the technical objectives and will be used to integrate the scope, schedule and cost baselines into one structure. This is to ensure that all scope is identified, facilitate the assignment of work, define interrelated activities, and establish milestones at key decision points. Figure 1 is arranged to show the Summary Work Breakdown Structure (SWBS) and the Contractor Work Breakdown Structure (CWBS). The SWBS provides the general framework for the work and the products to be produced. The CWBS provides a more detailed breakdown of the specific results and products.

An FFTF Standby Project office (SPO) is currently being formed with project management by the Pacific Northwest National Laboratory (PNNL) and FDH. The WBS will be modified as necessary to reflect any changes that occur through the establishment of the SPO. 
HNF-SD-FF-SSP-056

Rev. 0, Page A-10

This page intentionally left blank. 


\subsection{RISK ASSESSMENT}

The risks associated with the Plan have been assessed following the guidance in DOE 4700.1 (Reference 1) and are shown Table 4-1 which identifies, assesses and provides the planned responses for known risks. Risk identification, assessment and response is necessary to ensure the activities are performed within the safety, cost and schedule restraints.

\subsection{TECHNICAL}

The overall technical risk is low. Qualified operating and maintenance personnel, equipment and proven technology will be used. The FFTF Standby Plan will be used to accomplish the work scope in a manner that minimizes risk. As examples, the work scope includes fuel washing, fuel offload, and surveillance and maintenance.

\subsection{SCHEDULE}

The overall schedule risk is low. The current planning and scheduling effort will be sustained to achieve the milestone and schedule objectives defined in the Advanced Reactors Transition MYWP (Reference 8). Change requests will be issued for all milestones impacted by Reference 9 and Reference 10 .

\subsection{COST}

The overall cost risk is low. Although institutional barriers, budget limitations and funding restrictions are historically difficult to predict, high priority will be given to assure adequate funding is available to maintain the FFTF in standby.

\subsection{ENVIRONMENTAL, HEALTH AND SAFETY}

The environmenta1, health and safety risks are low. All activities will comply with the Occupational Safety and Health Act (OSHA). The FFTF personnel have a long standing history of operating liquid metal and nuclear systems safely. This is expected to continue by maintaining a staff of trained operating, engineering and craft personnel who use approved procedures and tested equipment.

The risk for schedule delays related to the approval of environmental documentation was eliminated when the Finding of No Significant Impact (FONSI) was issued in May 1995. The Environmental Assessment for the FFTF (Reference 3 ) contains a copy of the finding. Maintaining the FFTF in standby does not compromise or invalidate the Environmental Assessment. 
Table 4-1 Risk Identification, Assessment \& Response

\begin{tabular}{|c|c|c|c|}
\hline Activity & $\begin{array}{c}\text { Risk } \\
\text { Identification }\end{array}$ & $\begin{array}{l}\text { Risk } \\
\text { Leve1 }\end{array}$ & Assessment-Response \\
\hline $\begin{array}{l}\text { Fuel Washing, } \\
\text { Cask Loading } \\
\text { and Storage }\end{array}$ & $\begin{array}{l}\text { Schedule and cost risk due } \\
\text { to insufficient number of } \\
\text { trained operators and } \\
\text { support staff. }\end{array}$ & Low & $\begin{array}{l}\text { Assessment Basis: Fuel washing to remove sodium } \\
\text { has been performed safely and successfully in the } \\
\text { FFTF Interim Examination and Maintenance (IEM) } \\
\text { cell for nearly } 15 \text { years. } \\
\text { Response: Maintain a high level of qualified } \\
\text { personnel, equipment and procedures. Continue } \\
\text { detailed scheduling of IEM cell activities. A } \\
\text { Readiness Assessment was conducted prior to } \\
\text { commencing fuel washing operations. }\end{array}$ \\
\hline $\begin{array}{l}\text { Fuel Washing, } \\
\text { Cask Loading } \\
\text { and Storage }\end{array}$ & $\begin{array}{l}\text { Fuel washing equipment } \\
\text { failures may delay the } \\
\text { schedule. }\end{array}$ & Medium & $\begin{array}{l}\text { Assessment Basis: Operating experience during } \\
\text { fuel washing operations in IEM Cell. } \\
\text { Response: Perform upgrades and preventive } \\
\text { maintenance work on the fuel washing equipment to } \\
\text { minimize unscheduled equipment downtime. The } \\
\text { fuel offload schedule is periodically adjusted to } \\
\text { account for actual fuel offload processing times } \\
\text { and major equipment failures. }\end{array}$ \\
\hline $\begin{array}{l}\text { Surveillance } \\
\& \\
\text { Maintenance }\end{array}$ & $\begin{array}{l}\text { This activity includes the } \\
\text { routine operation and } \\
\text { maintenance of the FFTF } \\
\text { Plant systems, equipment } \\
\text { and facilities. The major } \\
\text { activity is related to } \\
\text { circulating sodium. This } \\
\text { includes operating and } \\
\text { maintaining inert gas and } \\
\text { trace heating systems } \\
\text { safely. }\end{array}$ & Low & $\begin{array}{l}\text { Assessment Basis: These activities have been } \\
\text { conducted competently with an exceptional degree } \\
\text { of safety for nearly } 17 \text { years. } \\
\text { Response: Maintain a high level of qualified } \\
\text { personnel to support the operations and } \\
\text { maintenance of the FFTF systems, equipment and } \\
\text { facilities. }\end{array}$ \\
\hline
\end{tabular}




\begin{tabular}{|c|c|c|c|}
\hline Activity & $\begin{array}{c}\text { Risk } \\
\text { Identification }\end{array}$ & $\begin{array}{l}\text { Risk } \\
\text { Leve1 }\end{array}$ & Assessment-Response \\
\hline $\begin{array}{l}400 \text { Area } \\
\text { Interim } \\
\text { Storage } \\
\text { Area (ISA) }\end{array}$ & $\begin{array}{l}\text { The ISA is located in the } \\
\text { northeast corner of the } \\
\text { FFTF complex. A locked } \\
\text { gate provides controlled } \\
\text { access to the storage } \\
\text { area. The ISA is now } \\
\text { being used to store } \\
\text { washed, irradiated FFTF } \\
\text { fueled components in } \\
\text { shielded storage casks. } \\
\text { In addition to the FFTF } \\
\text { fuel, spent nuclear fuel } \\
\text { from the } 308 \text { Building is } \\
\text { stored in casks inside a } \\
\text { concrete storage vault } \\
\text { within the ISA. The risk } \\
\text { involves handling shielded } \\
\text { casks containing nuclear } \\
\text { fuel. }\end{array}$ & Low & $\begin{array}{l}\text { Assessment Basis: Fuel handling operations have } \\
\text { been conducted safely at the FFTF for nearly } 17 \\
\text { years. } \\
\text { Response: Test and qualify the cask handling } \\
\text { equipment prior to use. Maintain trained and } \\
\text { qualified fuel handling and crafts personnel. } \\
\text { Assure all safeguards and security requirements } \\
\text { are satisfied. }\end{array}$ \\
\hline
\end{tabular}


Table 4-I Risk Identification, Assessment \& Response

\begin{tabular}{|c|c|c|c|}
\hline Activity & $\begin{array}{c}\text { Risk } \\
\text { Identification } \\
\end{array}$ & $\begin{array}{l}\text { Risk } \\
\text { Level }\end{array}$ & Asses sment-Res ponse \\
\hline Cost-Funding & $\begin{array}{l}\text { Funding to support the } \\
\text { FFTF deactivation and } \\
\text { standby activities must } \\
\text { remain available. }\end{array}$ & Medium & $\begin{array}{l}\text { Assessment: Institutional barriers, budget } \\
\text { limitations and funding restrictions may delay } \\
\text { the schedule and increase costs due to } \\
\text { replanning. } \\
\text { Response: The RLS identifies those activities } \\
\text { that must be funded to support the FFTF } \\
\text { deactivation and standby activities within cost } \\
\text { and schedule limits. Although institutional } \\
\text { barriers, budget limitations and funding } \\
\text { restrictions are historically very difficult to } \\
\text { predict, high priority will be given to ensure } \\
\text { that adequate funding is available. Continue } \\
\text { providing accurate cost and schedule information } \\
\text { to the DoE to justify the minimum required } \\
\text { funding to achieve the schedule and milestone and } \\
\text { objectives safely. Continue efforts to reduce } \\
\text { the cost of all activities to minimize the impact } \\
\text { of future funding restrictions. }\end{array}$ \\
\hline A11 & $\begin{array}{l}\text { Addition of tasks not } \\
\text { related to the project } \\
\text { scope or goals. }\end{array}$ & Medium & $\begin{array}{l}\text { Assessment Basis: The cost and schedule } \\
\text { baselines for the known scope are as tight as } \\
\text { possible. The addition of administrative tasks } \\
\text { such as new DOE Orders, codification (i.e., rule } \\
\text { shifting from DOE Orders to the Code of Federal } \\
\text { Regulations) and Standards Requirements } \\
\text { Identification Documents (S/RID) with no budget } \\
\text { allowance will divert 1imited resources. } \\
\text { Response: Maintain close communications with the } \\
\text { FDH and the DOE to assure the addition of new } \\
\text { work scope, including unfunded work, is } \\
\text { minimized. }\end{array}$ \\
\hline
\end{tabular}




\subsection{PROJECT MANAGEMENT}

\subsection{MANAGEMENT STRATEGY}

The approach to manage the scope, cost and schedule baselines will follow the guidance in the following procedures:

DOE 4700.1 Project Management System (Reference 1)

WHC-CM-2-5 Management Control System (Reference 6)

The activities will be managed, controlled and reported upon to achieve the cost and schedule goals in the Plan and the RLS. All scope, schedule and cost changes, including the impact of TPA negotiations (Reference 5), will be managed by the baseline change control process described in Section 6.0.

\subsection{ORGANIZATION}

The FFTF Transition Project office Manager is responsible for the overall integration of the activities under the direction of the FFTF Project Director and concurrence of the FFTF SPO. This includes program integration, and preparation of the Work Breakdown Structure (WBS), the Resource Breakdown Structure, logic diagrams, and lower-tier schedules. This information is used to establish cost and schedule baselines for each element of the WBS, and make assignments to the performing organizations.

\subsection{MANAGEMENT CONTROL SYSTEM}

\subsubsection{Introduction}

The MCS (Reference 6), which is consistent with DOE 4700.1 (Reference 1), wil1 be used to effectively manage the baselines. The primary objective is to maintain the condition of the plant systems, equipment and personnel to preserve the option for plant restart within three and one-half years of a decision to restart, while continuing deactivation work which is consistent with the standby mode.

The following general baselines will be used:

1) Scope Baseline - defines all activities, including the labor and material resources consumed, and the resulting end products as governed by the MYWP (Reference 8 ). This encompasses satisfying all technical, quality, safety, environmental and operating requirements.

2) Cost Baseline - defines all cost-related aspects of the WBS cost accounts and work package elements in the FFTF Standby Plan and the RLS, and as governed by the MYWP (Reference 8 ).

3) Schedule Baseline - correlates the time-related activities as described in the FFTF Standby Plan and restrained by funding, labor and material resources. The MYWP (Reference 8 ) is the governing schedule. 
Modifications to the baselines, including the related milestones, will be controlled by the change control process described in Section 6.0 .

The MCS supports the flow of integrated cost and schedule information to the FFTF SPO and the DOE to ensure timely decision making. The MCS is also used to accomplish the following:

1) Provide a work breakdown structure that defines the work activities in a disciplined manner from the overall level to lower level work packages.

2) Provide scope, schedule and cost information in sufficient detail to measure and report activity progress and milestone achievement.

3) Facilitate the evaluation of scope, schedule and cost data. Identify trends or problems requiring management intervention.

All work plans will be evaluated and managed to ensure:

1) Available funding, labor and material resources support planned work.

2) Work is completed by the scheduled completion dates.

3) Future cost factors like increased labor rates and inflation are considered.

4) Continual monitoring and reporting performance to identify cost or schedule trends that may cause unfavorable deviations from the FFTF Standby Plan and the MYWP.

\subsubsection{Scope Baseline Management}

Management of the scope baseline will continue to be performed according to the MCS (Reference 6).

\subsubsection{Cost Baseline Management}

The cost baseline will continue to be managed such that the activities are completed within the cost estimates. Activity based cost estimates are prepared following the 0ffice of Waste Management EM-30 Cost and Schedule Estimating Guide (Reference 4).

\subsubsection{Cost Estimate Reviews}

Thorough reviews of cost estimates, including those related to maintaining the FFTF in standby and fuel washing, will be performed at least annually. The results of these reviews and any corrective action will be documented. These reviews shall assure the following requirements are met:

1) Cost estimates are consistent with the WBS and all approved changes.

2) Cost estimate assumptions are documented. 
3) Cost estimates for the Surveillance and Maintenance (S\&M) and for the Deactivation and Compliance (D\&C) activities are based upon historical cost data for the FFTF Plant.

4) Performance based cost estimates will be based upon detailed drawing or work package take-offs whenever practical. This is the preferred method of estimating. Performance estimates are bottoms-up, definitive cost estimates and should typically be $\pm 5 \%$ accurate. The cost estimates for manufactured, or fabricated items, may be supported by vendor quotes.

Parametric estimating techniques may be used when the design details are insufficient to prepare estimates based on actual quantities.

Parametric cost estimates are typically $\pm 20 \%$ accurate and are used during the conceptual phase.

Magnitude cost estimates may be used when the process and products are not defined and there is little information to base estimates upon. Magnitude estimates are typically $\pm 50 \%$ accurate.

5) Minimize the use of cost estimates based upon estimator experience without reference to known quantities and unit rates.

6) Base labor rates and productivity upon local rates and experience.

7) Ensure contingency allowances are properly applied. Contingency allowances are intended to cover unknown or unforeseen costs such as minor scope changes, design refinements, changes in market conditions, minor labor rate changes, and work stoppages due to normal weather conditions. Contingency allowances are not expected to cover impacts due to unforeseen items like prolonged labor strikes, weather disasters, changes in budgets, major scope additions, new regulations, or requirements beyond the control of management.

Contingency is not assigned to the operating portion of the budget (standby, surveillance, maintenance, and deactivation) because this work has more historical data from which accurate budgets can be estimated.

Cost estimates may also be performed by $D O E, R L$, or by independent estimators working for government.

\subsubsection{Cost Performance Monitoring}

Cost performance monitoring will include the generation, analysis and reporting of the following information at least monthly:

1) Cost performance and analysis data. Variances or deviations from the approved thresholds shall be analyzed. A corrective plan to resolve the variances shall be provided with the analysis. The MCS (Reference 6) shall be used to document and report this information.

2) Cost performance reports. The performance reporting requirements are given in Section 5.3.5. 
HNF-SD-FF-SSP-056

Rev. 0, Page A-18

\subsubsection{Schedule Baseline Management}

The FFTF standby and deactivation progress will be monitored and reported against the baselines, the critical path and all milestones at least monthly. The cause and corrective action for all schedule variances which exceed thresholds will be documented and reported.

\subsubsection{Performance Reporting}

The FFTF Transition Project office Manager will provide monthly performance reports summarizing activity progress, milestone status, cost status, and the plans to resolve problem areas following the guidance of DOE 4700.1 (Reference 1) and WHC-CM-2-5 (Reference 6 ). The reports will be used to monitor the scope, cost, and schedule baselines.

\subsubsection{Performance Reports}

The following information shall be reported:

1) Accomplishments and status for each major element or activity.

2) Problems and resolutions affecting the scope, cost or schedule baselines.

3) Significant open commitments.

4) Cost performance and contingency status.

5) Schedule performance against the critical path.

Exceptions or problems reported in prior months shall be reported monthly through their resolution.

\subsubsection{Report Distribution}

Distribution of the reports will follow WHC-CM-2-5 (Reference 6).

\subsubsection{Review Meetings}

The FFTF Transition Project Office Manager has the lead responsibility for the monthly Program Review Meetings. The agenda for these meetings will typically include:

1) Safety.

2) Work status and significant progress.

3) Significant problems and planned corrective actions.

4) Cost status and trends.

5) Contingency status.

6) Critical path status and schedule trends.

7) Priority efforts for the following three months.

Subsequent meetings will highlight the status and disposition of previously identified concerns or problems. 


\subsection{BUDGET, COST AND SCHEDULE PERFORMANCE MEASUREMENT}

The FFTF Standby Plan budget, cost and schedule baselines support the direction provided by Reference 9 and Reference 10 . The major steps in performance measurement and reporting are shown in Figure 5-1 and shall accomplish the following:

1) Provide timely and objective cost and schedule performance data.

2) Track actual progress against the baseline budget estimates, the schedule critical path, and all milestones.

3) Measure cost and schedule progress using earned value techniques.

4) Identify undesirable cost and schedule variances to facilitate management intervention.

5) Develop work-around plans to allay or mitigate unfavorable variances.

6) Prepare cost estimates and submit budget revisions when cost and schedule variances cannot be corrected within approved funding.

7) Support the FDH Project Status Report (PSR). The PSR is issued monthly.

8) Provide a variance analysis by WBS element highlighting situations that exceed reporting thresholds. The analysis shall include incremental and cumulative data and include a statement of the problem and the corrective action taken or planned. The thresholds assigned for all variances shall be based on the Budgeted cost of Work Scheduled (BCWS) shown below and required by WHC-CM-2-5, Procedure 3.1, (Reference 6).

$$
\begin{aligned}
& \text { BCWS }<\$ 500,000= \pm 10 \% \text { and } \pm \$ 10,000 \\
& \text { BCWS }>\$ 500,000= \pm \$ 50,000
\end{aligned}
$$

More stringent thresholds can be imposed at the direction of the DOE-RL, the FFTF SPO, the FFTF Project Director, or the FFTF Transition Project Office Manager. 
HNF-SD-FF-SSP-056

Rev. 0, Page A-20

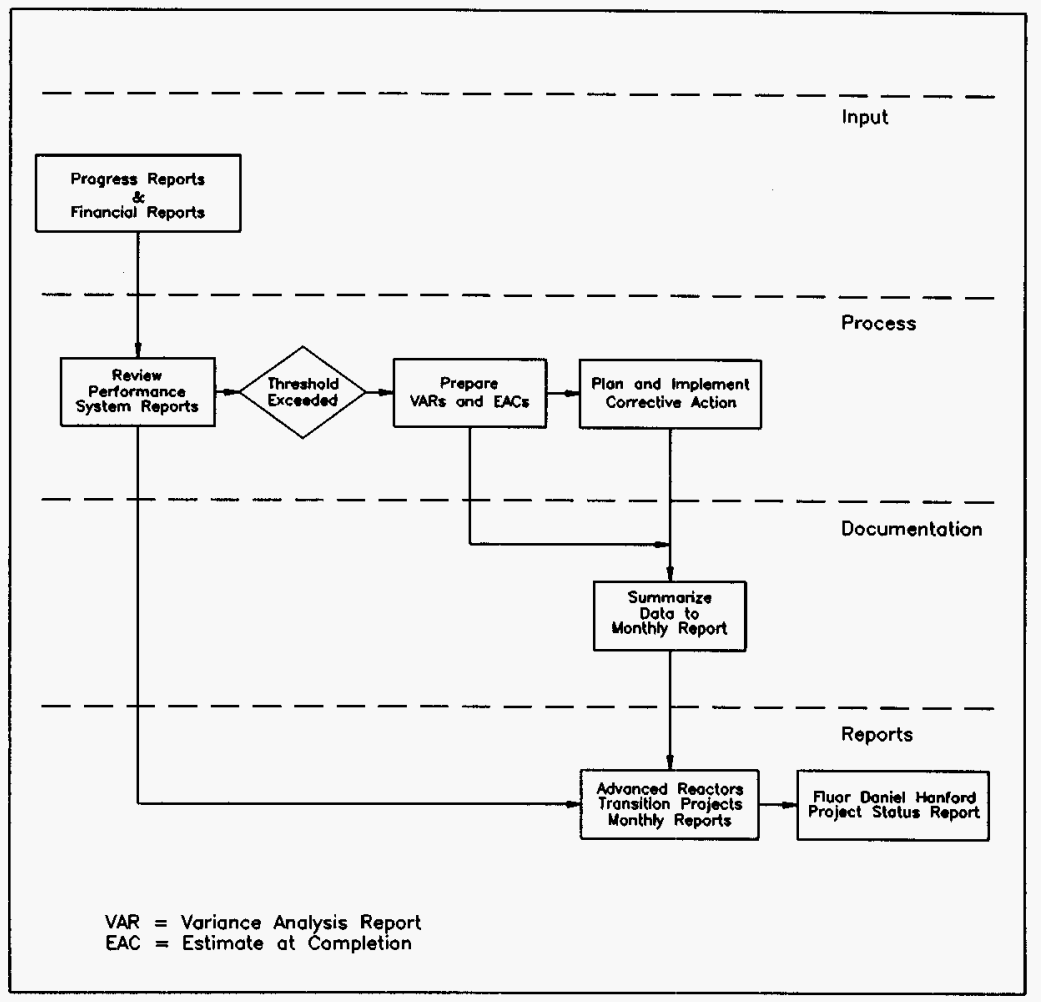

CADFEE: OA-RP.DWt

Figure 5-1 Performance Analysis and Reporting Process 


\subsection{BASELINE CHANGE CONTROL}

\section{1 CHANGE CONTROL BOARD}

The primary function of the baseline change control process is to manage changes to the scope, cost, or schedule baselines. The FFTF Project change Control Board (CCB) has been established to review and disposition all Class I changes. The CCB authority and operation is described herein.

The CCB membership shall consist of representatives from the organizations shown below. Others may be added at the direction of the CCB and may include senior management, technical advisors, and consultants.

FFTF Transition Project Office Manager - Chairman

FFTF Project Integration Team Leader - Secretary

FFTF Project Director

FFTF Deputy Project Director

FFTF Engineering Manager

FFTF Operations Manager

South Office Business Team Leader

FFTF Standby Project Office

RL FFTF Program Manager

Each CCB member, or their designated alternate, is empowered with the authority to make agreements and commitments for the organizations represented.

\subsection{CHANGE CONTROL BOARD OPERATION}

The FFTF CCB is authorized to approve Class I changes to the baselines for submission to the B\&W Hanford Company (BWHC) CCB for ultimate submittal to FDH and DOE-RL for final disposition. The thresholds are defined in Table 6-1. Changes shall be documented on a Baseline Change Request (BCR) form. The operation of the CCB shall be as follows:

\subsubsection{FFTF Change Control Board Chairman}

1) Preside over the CCB meetings and approve the CCB minutes.

2) Assure the approval level of the BCR compliments the change classification.

3) Coordinate actions requiring approval including requests for funding changes and changing controlled milestones.

4) Resolve comments and recommendations concerning the BCR disposition. 
HNF-SD-FF-SSP-056

Rev. 0, Page A-22

\subsubsection{FFTF Change Control Board Secretary}

1) Coordinate the submittal of FFTF Project approved BCRs to the BWHC CCB.

2) Prepare the meeting agenda and schedule CCB meetings if required (See Section 6.2.4).

3) Distribute the meeting agenda, minutes and BCRs.

4) Prepare and maintain the Change Control Log.

\subsubsection{Consultants}

The CCB may solicit input or advice from support function consultants before acting on a BCR. As examples, these may include Engineering, Operations, Quality Assurance, Safety, Environmental and Regulatory Compliance, Cost Estimating and Security. The support function consultants perform the following:

1) Review BCR prior to submission to the CCB Chairman.

2) Recommend action to disposition the BCR.

3) Evaluate BCR for technical, cost, schedule, or funding impacts in their area of expertise to assure impacts are realistically estimated.

\subsubsection{Change Control Board Meetings}

Unless requested by the FFTF Project Director, the FFTF Transition Project Office Manager, or the FFTF SPO, the CCB is not required to meet formally. Experience has shown that the CCB can normally accomplish its responsibilities without formal meetings by following the change control process described herein.

\subsubsection{Baseline Change Request Priority}

All changes shall be acted upon within the time frame related to the priority of the change. The change priorities are routine, urgent and emergency. The priority is assigned based upon how the change affects safety, quality, schedule, cost or performance. Each BCR shall be acted upon within the following time frames:

1) Routine - Within seven (7) working days after the BCR has been distributed for review.

2) Urgent - Determined to require an expedited response but does not meet the emergency change criteria.

3) Emergency - Within two (2) working days after the BCR has been submitted. These are usually changes to prevent the cessation of work. They may also be related to safety concerns, or unforeseen events, which could worsen if corrective action is delayed. 
Authorization to proceed with the corrective actions for emergencies may be obtained by telephone, electronic mail, or in person. The authority to proceed in this manner resides with the CCB Chairman. In any case, the change action will be taken promptly to ensure the change conditions are implemented in a safe, cost effective manner. The CCB Chairman shall follow-up to ensure any emergency change action is documented.

\subsection{BASELINE CHANGE REQUEST}

Each BCR shall include a detailed description of the change, cost estimate, schedule estimate and justification for the recommended course of action.

The FFTF Transition Project Office Manager shall notify the FFTF SPO of an impending Class I Baseline Change Request (BCR). Although informa1 notification is encouraged, formal documentation of the change by an approved $B C R$ is required. If necessary, this includes consulting with senior management, FDH, BWHC and customer-related review boards to obtain their concurrence before implementing the change.

The cost impact shall be furnished by WBS element and by the fiscal year of the expenditure. The schedule impact shall be based upon the RLS (Reference 7), or any impacted MYWP milestones (Reference 8).

A BCR may be needed for one or more of the following:

1) Satisfy design, construction, fabrication, installation, functional or performance requirements.

2) Changes in program funding or the Project Summary Work Breakdown Structure.

3) To revise resource requirements based on more detailed planning and estimating than was previously available.

4) New or revised regulatory requirements.

5) Meet safety requirements and correct conditions which could injure personnel or damage equipment.

6) Provide significant construction, fabrication, operating, cost or schedule improvements without compromising requirements.

7) Achieve a significant cost reduction without adversely affecting the FFTF Standby Plan or the RLS.

8) Changes to the master schedule milestone dates and descriptions (TPA, $\mathrm{DOE}-\mathrm{HQ}$, and $\mathrm{RL}$ ).

9) Major changes caused by factors like weather, disasters, and labor restraints beyond the control of management.

10) Changes required to offset general and administrative/site-wide support pool, department overhead, and service pool rates. 
All changes will be reviewed for their impact on compliance with governing documents and regulations (i.e. permitting requirements, DOE commitments, milestones, TPA negotiations and environmental requirements).

\subsubsection{Change $\mathrm{Classifications}$}

Changes to the scope, cost and schedule baselines are classified as Class I, Class II, or Class III, according to the magnitude of impact. The change classification also indicates the approval authority. The types of baseline changes and class are shown in Table 6-1.

A1though DOE 4700.1 (Reference 1) refers to Level 0 and Level I as DOE-HQ approval levels, the FFTF intends to use the terminology in WHC-CM-2-5 (Reference 6 ), which designates DOE-HQ changes as Class I.

It is not permissible to break a large change into several smaller changes to reduce the classification. Each change shall be identified by a single, stand-alone Baseline Change Request.

All changes to the scope, cost, and schedule baselines shall be processed as Class I or Class II changes. The change classifications are shown in Table 61 and are defined as follows:

Class I Changes that impact the following baselines:

Scope Baseline

Changes to the SWBS shown in Figure 1 of the FFTF Standby Plan.

Cost Baseline

Changes to the total estimated cost above established limits.

Schedule Baseline

Changes to scheduled completion dates for project activities shown in the FFTF Standby Plan Summary Schedule (See Figure 2 in the Plan). Modifications to controlled milestones.

Class II Scope, Cost or Schedule Baselines

Changes to the technical portions of the project, such as drawings and specifications, that do not affect the WBS, schedule, or the cost above established limits.

Changes to the cost or schedule baselines that would otherwise be Class III, except that they exceed the lower thresholds for Class II changes.

Note

The minimum classification assigned to modify FFTF milestones shall be Class II. The FFTF Project Director and FDH shall approve all changes to milestones. 
Class III Changes that do not meet the criteria for Class I or II, and are minor in nature. Class III changes do not impact the scope, cost and schedule baselines.

Unless directed otherwise by the DOE-RL FFTF Program Manager, the FFTF Project Director, or the FFTF SPO, change requests that impact out-year financial planning shall be processed as Class III changes. This is to reduce costs related to incorporating change requests into the RLS. The effect of these out-year changes will be approved in the subsequent MYWP.

\begin{tabular}{|c|c|c|c|}
\hline & Table 6-1 Baseline & lange $\mathrm{Cl}$ asses & \\
\hline \multirow{2}{*}{ Class } & \multicolumn{3}{|c|}{ Thresholds } \\
\hline & Scope & Cost & Schedule \\
\hline Leve1 1 & $\begin{array}{l}\text { Any change in scope } \\
\text { ident ified \& approved } \\
\text { for HQ Program } \\
\text { Manager/ Project } \\
\text { Manager Control }\end{array}$ & $\begin{array}{l}\text { Any Change } \geq \$ 5 \\
\text { million or } 10 \% \\
\text { TEC, whichever } \\
\text { is less }\end{array}$ & $\begin{array}{l}\text { Level I HQ } \\
\text { milestones } \geq 2 \\
\text { months }\end{array}$ \\
\hline $\begin{aligned} & \text { Class } 1 \\
&\text { (Level } 2)\end{aligned}$ & $\begin{array}{l}\text { Any changes to SWBS } \\
\text { *Any changes to } \\
\text { Functional Design } \\
\text { Criteria or scope } \\
\text { identified \& approved } \\
\text { for RL control }\end{array}$ & $\begin{array}{l}\text { Any change }<\$ 5 \\
\text { million or } \geq \\
\$ 50 \text { thousand }\end{array}$ & $\begin{array}{l}\text { Any change to } \\
\text { all baseline } \\
\text { milestones }\end{array}$ \\
\hline Class II & $\begin{array}{l}\text { Definitive Design } \\
\text { media }\end{array}$ & $\begin{array}{l}<\$ 50 K \\
\geq \$ 5 K\end{array}$ & $\begin{array}{l}\text { Level } 3 \\
\text { milestones on } \\
\text { Project Master } \\
\text { Schedule }<1 \\
\text { month }\end{array}$ \\
\hline Class III & $\begin{array}{l}\text { Changes other than } \\
\text { Class I or Class II }\end{array}$ & $<\$ 5 K$ & $\begin{array}{l}\text { Level } 4 \\
\text { milestones, or } \\
\text { any change }\end{array}$ \\
\hline
\end{tabular}

PSWBS = Project Summary Work Breakdown Structure

* $\quad=$ RL Program Approval

NOTE: The minimum classification assigned to modify FFTF milestones shall be Class II. The FFTF Project Director and FDH shall approve all changes to milestones. 
HNF-SD-FF-SSP-056

Rev. 0, Page A-26

\subsubsection{Change Request Review and Approval}

The individuals or groups responsible for reviewing and approving BCRs are shown in Table 6-1. If it becomes necessary to disapprove a BCR, the reason for the disapproval shall be stated on the BCR, or in a letter from the disapproving authority. The review and approval process of a BCR can be improved if the FFTF Cost Account Manager and the FFTF Budget Analyst are consulted when the BCR is generated.

Class I Acted upon by the CCB upon completion of the applicable reviews. In some cases, the change classification may necessitate a review and approval by a higher level BWHC, FDH, or customer-established CCB.

Class II Acted upon by BWHC.

Class III Acted upon by BWHC.

\section{Note}

All Class I and II BCRs will be submitted by BWHC to FDH for approval. Class II BCRs do not require RL approval. 
Table 6-2 Baseline Change Request Review and Approval

\begin{tabular}{|c|c|c|}
\hline $\begin{array}{l}\text { Change } \\
\text { Class }\end{array}$ & Approved by & Reviewed by \\
\hline I & $\begin{array}{l}\text { FFTF Project Director } \\
\text { BWHC CCB } \\
\text { FDH } \\
\text { DOE-RL Manager Facilities } \\
\text { Transition }\end{array}$ & $\begin{array}{l}\text { - FFTF Cost Account Manager } \\
\text { - South Office Business Team Leader }{ }^{1} \\
\text { - FFTF Transition Project Office } \\
\text { Manager } \\
\text { - FFTF Deputy Project Director } \\
\text { - FFTF Standby Project Office }\end{array}$ \\
\hline I I & $\begin{array}{l}\text { FFTF Transition Project } \\
\text { Office Manager } \\
\text { FDH }\end{array}$ & $\begin{array}{l}\text { - FFTF Cost Account Manager } \\
\text { - South Office Business Team Leader }{ }^{1} \\
\text { - FFTF Deputy Project Director }\end{array}$ \\
\hline I I I & $\begin{array}{l}\text { Team Leader South office } \\
\text { Business } 1\end{array}$ & - FFTF Cost Account Manager \\
\hline
\end{tabular}

Notes:

1 Business Team Leader reviews BCRs after review by the FFTF Cost Account Manager and the FFTF Budget Analyst.

2 Refer to Table 6-1 for the scope, cost and schedule thresholds for Class I, II and III BCRs. 
HNF-SD-FF-SSP-056

Rev. 0, Page A-28

\subsubsection{Change Request Distribution}

The CCB Secretary shall distribute all Baseline Change Requests to the organizations shown below.

\begin{tabular}{||c|c|c|c||}
\hline \multicolumn{2}{|c||}{ Table 6-3 Baseline Change Request Distribution } \\
Organization & \multicolumn{3}{c||}{ BCR Class } \\
\cline { 2 - 4 } & I & I I & III \\
\hline FFTF Transition Project Office (P/X Scheduling) & Yes & Yes & Yes \\
\hline RL FFTF Program Manager & Yes & No & No \\
\hline FFTF Cost Account Manager & Yes & Yes & Yes \\
\hline South Office Business Team Leader & Yes & Yes & No \\
\hline FFTF Standby Project 0ffice & Yes & Yes & No \\
\hline
\end{tabular}




\subsection{CHARTER}

\subsection{INTRODUCTION}

The FFTF Project Director is responsible for implementing the requirements in Reference 9 and Reference 10 as directed by the FFTF SPO. The responsibility for planning, integrating, monitoring and reporting the work activities has been assigned to the FFTF Transition Project Office Manager.

The primary objective during the standby period is to maintain the condition of the plant systems, equipment and personnel to preserve the option for plant restart within three and one-half years of a decision to restart, while continuing deactivation work which is consistent with the standby mode.

\subsection{MANAGEMENT TEAM}

The FFTF management team is in place and is described below. The management team has shown an excellent ability to achieve performance, milestone and schedule requirements in a safe and cost effective manner.

\subsubsection{Department of Energy}

DOE provides programmatic direction through the Richland Operations office.

\subsubsection{Richland Operations Office Transition Program Division (RL)}

The RL FFTF Program Manager is responsible for implementing programmatic direction from the DOE.

FFTF Program Manager (RL)

FFTF Lead Program Engineer (RL)

\subsubsection{FFTF Standby Project Office}

Director (PNNL)

Deputy Director (FDH)

\subsubsection{FFTF Project}

Project Director (BWHC)

Deputy Project Director (BWHC)

\subsubsection{FFTF Transition Project Office}

Project Office Manager (BWHC) 


\title{
7.2.6 Support Functions
}

The FFTF team support functions are listed below.

\author{
Engineering \\ Maintenance \\ Operations \\ Training \\ Transition Project office \\ Quality Assurance \\ Environmental \& Regulatory Compliance \\ Radiological Control \\ Safeguards \& Security \\ Safety \\ Configuration Control and Data Management
}

Other organizations and functions may be included with the approval of the FFTF Project Director, or the FFTF Transition Project office Manager.

Independent oversight is provided by organizations such as the following:

FDH Environment, Safety and Health

FDH Quality Assurance

DOE-RL Office of Environment, Safety and Health

Hanford Advisory Board (HAB)

Environmental Protection Agency (EPA)

Washington State Departments of Ecology and Health

\subsection{FFTF TRANSITION PROJECT OFFICE}

The FFTF Transition Project Office Manager has the lead responsibility for the overall integration of the work activities, including cost and schedule control. The responsibility also includes:

\subsubsection{Team Building}

The FFTF Transition Project Office Manager is responsible for developing and maintaining a team that achieves the performance, milestone and schedule requirements in a safe and cost effective manner. As examples, the team members may include personnel from organizations representing Operations, Engineering, Maintenance, Training, Safety, Quality Assurance, Regulatory Compliance, and Federal and State Government agencies.

\subsubsection{Planning and Baseline Schedule Development}

1) Plan, integrate and manage the FFTF activities. This includes assuring that the labor and material resources needed for fuel washing, fuel disposal, preventive maintenance and plant preservation are utilized in a safe and cost effective manner.

2) Establish milestones which support the schedule including DOE and TPA requirements. 
3) Provide the Work Breakdown Structure, logic diagrams, and lower-tier schedules to establish baselines for the preparation of supporting resource loaded schedules and cost estimates.

4) Ensure the RLS supports the objective to perform fuel washing and maintain the FFTF in standby.

5) Anticipate and expedite the resolution of problems to minimize schedule impacts.

6) Update the PIan and the RLS whenever required to reflect changes in scope, schedule or funding.

7) Maximize the use out-source procurement and private-sector contracts whenever cost effective.

\subsubsection{Change Control}

1) Assure all changes which impact the scope, cost or schedule baselines are documented on approved BCRs as directed by the BWHC Business office, the FFTF SPO, FDH and DOE-RL.

2) Establish a Change Control Board which includes the customer and the FFTF management. Serve as the board chairman.

\subsubsection{Budget and Cost Estimates}

1) Prepare cost estimates to justify budgets and support financial planning.

2) Prepare and submit financial planning documents such as the MYWP and the 10-Year Plan.

\subsubsection{Technology}

1) Serve as the central technology coordinator for the application of sodium process technology to reduce costs and enhance the effectiveness of the standby period.

2) Maintain active liaison with liquid metal reactor facilities, both domestic and foreign, so that lessons learned at other sites may be applied.

\subsubsection{Project Reports and Records}

1) Measure and report performance using earned value and variance analysis techniques as described in WHC-CM-2-5 (Reference 6).

2) Establish and maintain the FFTF technical files and records. 
HNF-SD-FF-SSP-056

Rev. 0, Page A-32

This page intentionally left blank. 


\subsection{REFERENCES}

1. DOE 4700.1

2. DOE 0 430.1

3. DOE/EA-0993

4. No Doc Number

5. No Doc Number

6. $W H C-C M-2-5$

7. WHC-SD-FF-SSP-050

8. WHC-SD-FF-SSP- 052

9. Memorandum

10. Letter
Project Management System, U.S. Department of Energy, Washington, D.C.

Life-Cycle Asset Management, U.S. Department of Energy, Washington, D.C.

Environmental Assessment, "Shutdown of Fast Flux Test Facility, Hanford Site," includes Finding of No Significant Impact, May 1995, U.S. Department of Energy, Richland, Washington.

Cost and Schedule Estimating Guide, Office of Waste Management, U.S. Department of Energy, Washington D. C.

Ecology, EPA, and DOE, 1995, "Tentative Agreement on Facility Transition," Hanford Federal Facility Agreement and Consent Order, as amended, Washington State Department of Ecology, U.S. Environmental Protection Agency, and U.S. Department of Energy, $01 y m p i a$, Washington. [Tri-Party Agreement]

Management Control System, Westinghouse Hanford Company, Richland, Washington.

Advanced Reactors Transition Program Resource Loaded Schedule, Westinghouse Hanford Company, Richland, Washington.

Advanced Reactors Transition Fiscal Year 1997 Multi-Year Work Plan WBS 7.3, Revision 2, Westinghouse Hanford Company, Richland, Washington.

Eldon W. Joersz, Major General, USAF, Principal Deputy Assistant Secretary for Military Application, Tritium Project 0ffice, Memorandum for the Secretary, Department of Energy, "ACTION: Decision on maintaining the Fast Flux Test Facility in a hot standby capacity to permit the Department to make a decision by 1998 on whether the facility should play a future role in the Department of Energy's tritium production strategy, if appropriate." (Approved by the Secretary of Energy, January 17, 1997.

S. A. Sieracki, Contracting Officer, RL, to H. J. Hatch, President, FDH, "Contract No. DE-AC06-96RL13200: Advanced Reactors Transition (ART) Program Direction," 97-TPD-003, January 18, 1997. 
HNF-SD-FF-SSP-056

Rev. O, Page A-34

This page intentionally left blank. 
HNF-SD-FF-SSP-056

Rev. 0, Page B-1

\section{APPENDIX B}

\section{FFTF STANDBY PLAN SYSTEM STATUS}


HNF-SD-FF-SSP-056

Rev. 0, Page B-2

This page intentionally left blank. 


\section{APPENDIX B \\ FFTF STANDBY PLAN SYSTEM STATUS}

\subsection{FFTF SYSTEMS}

The plant systems will remain in their current configuration with the exception of those which will be restarted or reconfigured for the purpose of preventing further plant degradation. The systems are divided into three groups as shown in Table B1:

Group A Those that will remain in their currently shutdown condition.

Group B Those that have been shut down but will be partially or fully restored in order to prevent system degradation or to support an associated system from degrading.

Group C Those that will remain in their current operational status.

The FFTF systems status during the standby period are described below. The sections in bold type describe actions proposed during the standby period. The proposed actions will be prioritized and performed within the constraints of funding and staffing availability.

\subsection{Systems Status During Standby}

\section{$11 \mathrm{~A} 115 \mathrm{KV}$ BPA Electrical Yard 451-B and $13.8 \mathrm{KV}$ Transmission Lines}

This system provides all electrical power from the Bonneville Power Administration (BPA) electrical grid to the 400 area including FFTF. It will remain in operation supplying power to all facilities within the 400 area. It will continue to provide power for the surveillance of FFTF.

Ownership of the 451-B Substation is shared between BPA and FFTF. BPA has the ownership and maintenance of the transmission lines up to the $115 \mathrm{KV}$ air switches on the primary side of power transformers, TRRl and TRR2. FFTF has ownership of the remaining equipment at the 451-B Substation; this includes the power

transformers, load centers $\mathrm{H}-11$ and $\mathrm{H}-12$, and the $\mathrm{DC}$ battery system.

\section{$11 \mathrm{~B} 115 \mathrm{KV} / 13.8 \mathrm{KV}$ Transformers, Electrical Yard 451-A and Station Ground Grid}

Electrical Substation 45l-A provides the main preferred $13.8 \mathrm{KV}$ electrical power to FFTF. This substation will remain operational during the standby period.

Proposed Action System 11B: Perform selected preventative maintenance and repairs on high voltage electrical equipment which had been canceled during shutdown planning due to the 1 imited remaining service time. 
HNF-SD-FF-SSP-056

Rev. 0, Page B-4

\section{$\underline{12 A} \quad 125$ Volt DC 1-E System}

This system provides uninterruptible power to safety systems required for public protection and is qualified per Institute of Electrical and Electronic Engineers (IEEE) Standard 308. The system loads that are no longer required per the FSAR have been de-energized and will remain de-energized during the standby period. The batteries and distribution system will remain operational during the standby period.

\section{$\underline{12 B} \quad 13.8 \mathrm{KV}$ System}

The $13.8 \mathrm{KV}$ Electrical System that provides power to FFTF will remain operational.

Proposed Action System 12B: Perform selected preventative maintenance and repairs on electrical equipment which had been canceled during shutdown planning due to the limited remaining service time.

\section{$\underline{12 C} \quad 2.4$ KV System}

This system consists of $13.8 \mathrm{KV}$ to $2.4 \mathrm{KV}$ transformers and switchgear for electrical protection and distribution. The system provides electrical power to the Main Heat Transport System (MHTS) pumps, Dump Heat Exchanger (DHX) fans, primary Control Rod Drive Mechanism (CRDM) MG-set, and the Ex-containment Chilled Water Chillers. This system will remain operational during the standby period.

Proposed Action System 12C: Perform selected preventative maintenance and repairs on electrical equipment which had been canceled during shutdown planning due to the limited remaining service time.

\section{D 480 Volt AC Normal Load Centers}

This system distributes 480 VAC power to electrical breaker panels, motor control centers, lighting load centers and directly to large equipment. This system will remain operational during the standby period.

Proposed Action System 12D: Perform selected preventative maintenance and repairs on electrical equipment which had been canceled during shutdown planning due to the limited remaining service time.

\section{E 480 Volt AC Emergency Load Centers}

This system distributes 480 VAC power to safety related electrical breaker panels, motor control centers and lighting load centers. Since the two diese 1 generators have been previously shutdown, the load centers now have backup emergency power from one gas turbine generator.

Proposed Action System 12E: Perform selected preventative maintenance and repairs on electrical equipment which had been canceled during shutdown planning due to the limited remaining service time.

\section{F Lighting}

This system distributes power to equipment providing lighting throughout the plant. This system will remain operational during the standby period. 


\section{G Low Voltage AC Systems Regulated and Non-regulated}

This system provides low voltage 120 VAC power from a reducing transformer and breaker panels to individual loads including lighting, instruments, and control panels. The low voltage power systems will remain operational during the standby period.

\section{H Emergency Diesel and Turbine Generators}

This equipment provides on-site emergency power generation to loads that were important for plant equipment protection during reactor operation in case of a loss of all off-site power sources. The diesel generators have been secured and a11 support fluids drained from the fuel and $0 i 1$ systems. The fuel oil storage tanks have been removed from the ground and excessed.

Proposed Action System 12H (diesels): Visually inspect a number (to be determined by Engineering) of the diesel crankshaft/rod bearings. Depending on the inspection, refill the diesel lube oil system and periodically turn the diesel crankshaft manually to prevent degradation of the crankshaft/rod bearings.

The Gas Turbine Generator and its systems will remain operational during the standby period.

Proposed Action System 12H (turbine): Perform selective preventative maintenance (vendor inspection) that was placed on hold. Install a leak detection system for the Turbine Generator fuel oil storage tank in order to comply with changes to the Washington State Administrative Code. Move the starting diesel cranking power and control power batteries to a location that allows a safer access for servicing.

\section{J Zero Time Outage - 120 Volt AC System}

This system provides uninterruptible power to safety systems required for public protection and is qualified per IEEE Standard 308. The Zero Time Outage Systems are no longer required by the FSAR and have been completely de-energized. They will remain shutdown during the standby period.

\section{K 480 Volt Motor Control Centers}

This system provides electrical protection and start/stop control function for motor loads. This system will continue to remain operational during the standby period.

Proposed Action System 12K: Perform selected preventative maintenance that was placed on hold.

\section{$12 \mathrm{~L}$ Freeze and Cathodic Protection}

This system includes trace heating of outside water piping and cathodic protection of underground piping and tanks. The cathodic protection to the $\mathrm{DHX}$ West and South heating oil tanks was disconnected to allow construction of the Sodium Storage Facility (SSF). The cathodic protection for the DHX East tank was turned off to minimize maintenance requirements.

Proposed Action System 12L: Reconnect cathodic protection for DHX South and West tanks, and re-enable cathodic protection for the DHX East tank. 
HNF-SD-FF-SSP-056

Rev. 0, Page B-6

\section{$12 M \quad$ Non-1E 125 VDC Battery System}

This system provides 125 VDC power for operation of all normal switchgear breakers and protective relays. This system will remain operational during the standby period.

\section{Fuel Storage Facility Electrical}

The FSF Substation receives power directly from the 451-B Substation and provides power to all FSF systems. This substation will remain operational to provide power to FSF.

\section{A FFTF and Fuel Storage Facility Communications System}

This system provides in-plant telephone, radio, and paging capabilities. This system remains operational during the standby period to provide needed plant communication and emergency preparedness functions.

Proposed Action System 15A: Remove the public address system back up battery bank and replace with a DC power supply.

\section{Support Buildings and Structures}

Most lead shielding (bricks, etc.) that was removed from its original configuration has been excessed. The support buildings and structures are structurally sound and in good condition.

Proposed Action System 21: Perform the normal 20 year re-coat of the DHX electrical room roofs.

\section{$21 \mathrm{~A}$ Control Panels Outside Reactor Containment Building}

Control panels necessary to support all operating systems as described in this document remain available for operation.

\section{B Cranes and Hoists Outside Reactor Containment Building}

The Reactor Service Building (RSB) and the Fuel Storage Facility (FSF) cranes remain operational to support spent nuclear fuel offload Deactivation and Compliance (D\&C) activities during the standby period.

\section{Fuel Storage Facility Land Improvements and Building Structures}

The Fuel Storage Facility Building will remain intact and operational during the standby period.

\section{A Well Water System}

This system provides and stores well water for sanitary and fire water supplies throughout the 400 Area. It will remain in service to insure that a supply of fire protection water exists for the 400 Area buildings. The water will continue to be chlorinated to provide drinking water to the facilities in the 400 Area.

\section{B Sanitary Water System}

This system pumps and distributes chlorinated sanitary water throughout the 400 Area. It will remain in service as required to support occupied buildings. 


\section{C Cooling Tower System}

This system uses evaporative cooling to provide a final heat sink for cooling of auxiliary systems. Three of the eight cooling towers have been laid up and will remain in that condition during the standby period. The remainder of the system remains operational.

Proposed Action System 23C: Install protective plastic covers over the laid up towers to prevent further corrosion of the sheet metal and begin a program to rotate the fan bearings. Install a coating on the interior sheet metal of the operational towers to prevent further corrosion. Determine a method to reduce the cooling tower sump waste water Total Dissolved Solids (TDS) to within the requirements of the Washington State Administrative Code.

\section{D Cooling Water Systems}

This system circulates an ethylene-glycol solution to transfer heat from auxiliary systems to the cooling towers. These auxiliary systems include the In-containment and Ex-containment Chilled Water Systems, Mobiltherm ${ }^{\mathrm{T}}$ System, air compressors, Radioactive Argon Processing System (RAPS) and Ce11 Atmosphere Processing System (CAPS) compressors, and MHTS pump liquid rheostats. The Mobiltherm ${ }^{T M}$, RAPS \& CAPS cooling, MHTS primary pump liquid rheostats, and one Ex-containment chiller (E-21) have been shutdown and their cooling water flow secured and will remain in that condition during the standby period.

Proposed Action System 23D: Install relief valve discharge catch system to prevent a glycol discharge to the environment.

\section{F Ex-Containment Chilled Water System}

This system uses refrigeration units to transfer heat from an ethylene-glycol chilled water solution to the Cooling Water system. The chilled water is circulated throughout the plant to cool the Sodium Removal System and H\&V units outside of the RCB. One of the four chillers (E-21) has been shutdown/laid up and will remain in that condition during the standby period. The other three chillers remain operational.

Proposed Action System 23F: Perform modification to convert the three operable chillers from freon R-12 to CFC free R-134a, utilizing the Carrier freon buy-back program. Upgrade the control panels for at least two of the operable chillers. Install a hot gas bypass system for each operable chiller to preclude damage during low load operations.

\section{G In-Containment Chilled Water System}

This system uses refrigeration units to transfer heat from an ethylene-glycol chilled water solution to the Cooling Water System. The chilled water is circulated throughout the RCB as well as HTS-South to cool inert gas coolers and containment atmosphere recirculation coolers.

Proposed Action System 23G: Perform modification to convert the four chillers from freon R-12 to CFC free R-134a, utilizing the Carrier freon buy-back program. Upgrade at least one of the ICCW chiller control panels (two have already been upgraded). 
HNF-SD-FF-SSP-056

Rev. 0, Page B-8

\section{H Process and Sanitary Drain System}

This system will remain in service as required to support any occupied buildings.

Proposed Action System 23H: Pump out the silt build up in the plant dry wells to restore their drainage capability.

\section{J Instrument Air System}

This system provides compressed dried air primarily for plant instrumentation and remotely operated valves. This system remains operational.

Proposed Action System 23J: Replace the rubber hoses with permanent piping on the T-196 air dryer, which originally was a temporary installation but now is a permanent modification.

\section{L Diesel Fuel System to Diesel Generators}

These systems have been secured and all oil has been drained. The storage tanks have been drained, removed from the ground and excessed.

\section{M Heating $0 i 1$ to Dump Heat Exchanger Heaters}

This system supplies heating oil to oil-fired preheaters that will keep the DHX module sodium from freezing if sodium pumping or sodium flow is lost due to module isolation. This system will remain operational during the standby period.

Proposed Action System 23M: Evaluate the installation of a spill protection system and overfill alarm pending anticipated changes in the Washington State Administrative Code requirements.

\section{P Service Air (utility and breathing)}

The system will remain operational.

\section{R Demineralized Water System}

This system uses resin beds to treat sanitary water for providing demineralized water to the MHTS pump liquid rheostats and the Sodium Removal System. It will remain operational.

\section{S Mobiltherm System}

This system circulates an oil (trade named Mobiltherm ${ }^{\text {TM }}$ ) to transfer heat from the Interim Decay Storage (IDS) and primary cold trap NaK cooling systems to the cooling Water system. Due to low heat loads, it has been drained and secured. A temporary nitrogen inerting connection was installed following drain of the Mobiltherm ${ }^{\mathrm{m}}$. This nitrogen inerting will continue during the standby period.

\section{3y Fuel Storage Facility Auxiliary Systems}

This system consists of the sanitary water and drains of FSF. It will remain operational. 


\section{Fuel Storage Facility Chilled Water System}

This system uses a refrigeration unit to chill an ethylene-glycol solution which then cools the FSF vessel vault cooling system. It will remain operational.

\section{A Radioactive Liquid Waste System}

The system stores and provides transfer capability for liquid waste, primarily from the Sodium Removal System. The system will remain operational.

\section{A Reactor Containment Building H\&V System}

This system provides fresh air, cooling, and pressure control for the Reactor Containment Building (RCB) atmosphere and includes redundant supply and exhaust units, recirculation coolers, associated distribution ducts, and High Efficiency Particulate Absolute (HEPA) filtering capability. Three of the five recirculating coolers have been laid up, and will remain so during the standby period. The remainder of the system will remain operational.

\section{B oxygen Monitoring}

This system consists of oxygen monitors and alarm capability for all general plant access areas with a potential for an inert atmosphere. This system will remain operational.

\section{D Control Building and Auxiliary Equipment Building East H\&V System}

This ventilation system provides fresh air, cooling, heating, and pressure contro1 for the Control Building and Auxiliary Equipment Building (AEB) East; and includes all supply and exhaust units, heaters, recirculation coolers,

distribution ducts and HEPA filtering capability for the Survey Area East. It also includes the Life Support System for Control Room Habitability. Severa] of the recirculating coolers have been laid up. The balance of the system will remain operational during the standby period.

Proposed Action System 25D: Temporarily restart the Primary CRDM MG Set room and the Primary CRDM cabinet room recirculating coolers to support control rod operability checks.

\section{$25 E$ Reactor Service Building and AEB-West HEV System}

This ventilation system provides fresh air, cooling, and heating for the Reactor Service Building (RSB) and AEB-West and includes al1 supply and exhaust units, heaters, recirculating coolers, and distribution ducts. Several of the recirculating coolers have been laid up. The balance of the system will remain operational for the standby period.

Proposed Action System 25E: Temporarily restart the Secondary CRDM MG Set room and the Secondary CRDM cabinet room recirculating coolers to support control rod operability checks. 
HNF-SD-FF-SSP-056

Rev. 0, Page B-10

\section{F Heat Transport System and Dump Heat Exchanger Building H\&V System}

This ventilation system provides fresh air, cooling, and heating for all Heat Transport System (HTS) and DHX Buildings and includes all supply and exhaust units, heaters, recirculation coolers and distribution ducts. It also provides HEPA filtering capability for the primary cover gas sampling cells in HTS-South. The portions of this system required to maintain building H\&V and HTS-South HEPA filtering capability will remain operational during the standby period.

\section{G Closed-Loop System H\&V System}

This ventilation system provides fresh air, cooling, and heating for all cells containing secondary Closed-Loop System (CLS) equipment and includes all supply and exhaust units, heaters, recirculation coolers and distribution ducts. This system has been shutdown and de-energized, with the exception of two fans that are required for ventilation of below-grade areas of HTS-East and HTS-West. The system will remain in this configuration during the standby period.

25H Radioactive Processing System/Cell Atmosphere Processing System H\&V System

This system provides ventilation and cooling to the normally closed cells containing the RAPS and CAPS systems and the Radioactive Liquid Waste System. This system was shutdown and deenergized when the RAPS and CAPS compressors were shutdown. It will remain shutdown during the standby period.

\section{J Reactor Head Compartment/Cavity Gas Cooling System}

This system interfaces with the In-containment Chilled Water System to provide air cooling to the reactor head compartment and nitrogen cooling to the reactor cavity, CROMs, Low Leve] Flux Monitors (LLFM)s, and Center Island. The inert gas blowers for the CRDMS, LLFMs, and one reactor cavity blower have been shutdown.

Proposed Action System 25J: Megger, grease, and run the blowers for vibration analysis of the bearings. Restore the LLFM cooling system to provide cooling to the LLFM detectors. Periodically jog the CRDM blowers to prevent bearing damage, and run as required to provide CRDM cooling during control rod operability tests.

\section{K Interim Decay Storage Vessel and Tank Cell Gas Cooling System}

This system interfaces with the In-containment Chilled Water System to provide nitrogen cooling for the IDS vessel cell and other auxiliary liquid metal systems. This system will remain operational.

Proposed Action System 25K: Reinstate vibration monitoring on large system blowers.

\section{L Closed-Loop Gas Cooling System}

This system interfaces with the In-containment Chilled Water System to provide nitrogen cooling for the cells containing closed-loop components and piping as well as the in-containment portion of the primary Sodium Sampling System. It has been shutdown and de-energized. The cells and piping have been vented to atmosphere. The coolers are being periodically jogged to prevent bearing damage. 


\section{M Heat Transport System Gas Cooling System}

This system interfaces with the In-containment Chilled Water System to provide nitrogen cooling for the cells containing primary MHTS components and piping. It will remain operational.

Proposed Action System 25M: Reinstate vibration monitoring on large system blowers.

\section{N Interim Examination \& Maintenance Cel1/Fuel Subassembly Gas Cooling System}

This system interfaces with the In-containment Chilled Water System to provide argon cooling for the IEM cell and its nuclear fuel Subassembly Cooling System. This system will remain operational.

Proposed Action System 25N: Replace the outdated programmable logic control system, which has exhibited continued failures, with a more reliable control system. Megger, grease and run the shutdown blowers for vibration analysis of the bearings.

\section{W Meteorological System}

The system has been shutdown and de-energized. It will remain de-energized during the standby period.

\section{X Fuel Storage Facility Building H\&V}

This ventilation system provides fresh air, cooling, and heating for FSF and includes all supply and exhaust units, heaters, recirculation coolers and distribution ducts. The system will remain operational during the standby period.

\section{$25 Y$ Fuel Storage Facility Oxygen Monitoring}

The oxygen monitors will remain operational during the standby period.

\section{Fuel Storage Facility Vault Cooling}

This system provides air cooling to the FSF vessel vault. This system will remain operational.

\section{A Fire Protection Water Supply}

This system includes three water storage tanks, one electric pump, and two diesel pumps. It will remain in service providing water to the hydrants outside of the FFTF plant and buildings.

Proposed Action System 26A: Perform scheduled inspection of the water storage tanks and ascertain the need to re-coat tank T-330. 


\section{B Fire Protection Sprinkler System - FFTF and Fuel Storage Facility}

This system will remain operational. The aqueous film-forming foam (AFFF) has been drained and was disposed in accordance with applicable regulatory requirements. The system will remain drained during the standby period.

Proposed Action System 26B: Perform internal inspection of the AFFF water and foam tanks to determine if any preservation activities are necessary. Install backflow preventers for all fire protection sprinkler systems as required by the Washington State Administrative Code.

\section{C Fire Protection Gas System - FFTF and Fuel Storage Facility}

This system provides automatic halon fire suppression for rooms containing computer equipment and nitrogen flooding capability for rooms containing secondary sodium. The nitrogen flooding systems remain operational. The 135 and 404 computer room Halon systems remain operationa1, but are no longer compliance tested because electrical equipment is deenergized and combustible material is removed. Room 110 halon system remains operational and compliance tested.

\section{D Fire Alarm and Detection System - FFTF and FSF}

This system will remain in service during the standby period.

\section{A Reactor Containment Vessel}

The containment vessel remains structurally intact. Periodic maintenance to preserve vessel integrity continues to be performed as required. Containment vessel testing however, has been deferred. The Equipment Air Lock (EqAL) will continue to operate with the inner door normally open and the outer door normally closed unless equipment moves through the EQAL are in progress. Both Personnel Airlock (PAL) doors will remain open for emergency egress.

\section{Control Panels for Reactor Containment Building}

The control panels necessary to support all operation will remain available during the standby period.

\section{B Reactor Containment Building Polar Crane}

The crane will remain operational to support a variety of activities in the Reactor Containment Building.

\section{E Reactor Containment Building Inert Cells}

Most of the cells have been vented to atmosphere via the sample connections through which the cell volumes are de--inerted. This was done to provide cell access for sodium drain activities. The cells will remain in this configuration during the standby period.

\section{M Containment Margins}

This system provides containment atmosphere sampling and scrubbing capability to mitigate the effects of a severe accident. It has been secured and de-energized. The system gas cylinders have been removed and recycled. The system will remain in this configuration during the standby period. 


\section{A Reactor Internals}

This system consists of the in-core assemblies, instrument trees, core structural components, and shielding. The irradiated nuclear fuel has been removed and replaced with non-fueled components. Immersion heaters are installed to provide the additional heat necessary to keep the primary system molten after the secondary loops are drained. The Materials Open Test Assembly (MOTA) glove boxes have been left in place with the sweep gas capped. The gas bottles have been removed and recycled. The Low Level Flux Monitor (LLFM) detectors are deenergized and their gas cooling is secured.

Proposed Action System 31A: Remove the immersion heaters from the reactor vessel and move to a storage location to facilitate instrument tree rotation. Rotate the instrument trees to ascertain their operational status and prevent further degradation. Restore cooling to the LLFMs and attempt to determine detector operability.

\section{B Control Rod Drive Mechanisms}

This system consists of the motor assemblies above the reactor vessel used to move the control rods.

Proposed Action System 31B: Connect the control rod drive lines and perform control rod operability testing to ascertain their operational status and prevent further degradation.

\section{A Reactor Enclosure}

The reactor enclosure consists primarily of passive, inaccessible components such as the vessel, head, supports, guard vessel and shielding. The active portions are the head heating and cooling system, fuel and test transfer ports, and the visual inspection equipment for the vessel.

Proposed Action System 32A: Complete the engineering study on how to best drain the reactor vesse1. Store for future use all hardware developed and procured for reactor drain. Evaluate condition of the outer head heaters and attempt to minimize their output to extend their lifetime.

\section{A In-Vessel Handling Machine}

These three machines perform fuel handling within the reactor vessel by moving the nuclear fuel assemblies between the core and the in-vessel storage modules. The controls and drive mechanisms are mounted on the reactor vessel head with the handling mechanism within the vessel.

Proposed Action System 41A: Operate the In-Vessel Handling Machines (IVHM)s to ascertain their operational status and prevent further degradation. 
HNF-SD-FF-SSP-056

Rev. 0, Page B-14

\section{C Core Component Handling and Storage}

This system includes the Closed-Loop Ex-vessel (handling) Machine (CLEM), the Bottom-Loading Transfer Cask (BLTC) handling machine, the installed storage facilities such as Interim Decay Storage (IDS), Core Component Conditioning Station (CCCS), Test Assembly Conditioning Station (TACS) and associated interface equipment used to perform all ex-vessel nuclear fuel handling. Al1 refueling machines, handling equipment, and storage facilities will remain operational during the standby period as D\&C activities continue.

Proposed Action System 41C: Perform maintenance and upgrades as described below to ensure machine reliability, which has degraded due to the age of these machines. Replace the CLEM control system computer and drive speed control system. Modify the CLEM preheaters in order to extend the life of the coldwall heaters. Clean the IDS visual indexing system and modify to add a functional cover and internal wiper for the mirror. Repair the inoperable IDS level sensor. Design and build a spare BLTC heater. Test and procure upgraded inflatable seals common to much of the component handling equipment. Repair instrumentation for the CCCS and TACS.

\section{C Core Component Container and Interim Storage Cask Handling Equipment}

The components are only a portion of system $41 \mathrm{C}$, but consist of those items needed by the Spent Nuclear Fuel (SNF) Project for future cask handling activities. This includes the components and interfacing hardware to support the Core Component Container (CCC), Interim Storage Cask (ISC) and T-3 Cask operations. This includes the Cask Loading Station (CLS), CLS elevator, Disposable Solid Waste Cask (DSWC) floor valve, Soljd Waste Cask (SWC), and ISC transporters, etc). These components will remain operational as D\&C activities continue during the standby period.

\section{D Interim Examination \& Maintenance Cell and Sodium Removal System}

This system is a shielded hot-cell that provides remote sodium washing, disassembly, and examination of irradiated core components. The IEM cell and Sodium Removal System will continue to remain operational and will be utilized for D\&C activities during the standby period.

Proposed Action System 410: Modify the Sodium Removal System's pre-filter to have backwash capability and change out the Ion Exchange System resin beds. Upgrade the instrumentation for the Sodium Removal System control pane1 and repair or modify Sodium Removal System solenoid valves. New equipment will be installed in the IEM Cell to handle, shear, clean, and load open test assemblies (28' and 40' components) into Disposable Solid Waste Casks (DSWCs).

\section{Fuel Storage Facility Fuel Handling}

This system consists of the refueling equipment that enables transfer of core components to and from the FSF vessel. This system and related components will remain operational during the standby period to support D\&C activities. 
44A Segmented Maintenance Cask

Component Removal/Installation Equipment

Cask and Handling Equipment

Component Disassemb1y/Assembly Equipment

Repair Tooling and Equipment

These components will be retained during the standby period.

\section{$51 \mathrm{~A}$ Heat Transport System Primary Coolant System}

The primary Reactor Core Coolant System consists of three coolant loops, each with a main sodium pump, support systems, and sodium piping. The system will remain operational on pony motor flow during the standby period.

Proposed Action System 51A: Megger the primary main motors and verify operation of the main motor space heaters. Inspect and exercise the primary motor liquid rheostats.

\section{B Heat Transport System Secondary Coolant System}

The Secondary Coolant System consists of three coolant loops, isolated from the radioactive primary coolant loops by the Intermediate Heat Exchangers (IHX)s, each with a main sodium pump, support systems, and sodium piping. This system will remain operational.

Proposed Action System 51B: Reinstate the preventative maintenance program for the sodium pump motors and their support systems, which was suspended for plant shutdown.

\section{C Heat Transport System Dump Heat Exchanger System}

This system provides the final heat sink for reactor core cooling by removing heat from the Secondary Coolant System with twelve sodium-to-air heat exchangers. It consists of main cooling fans, control dampers, structural components, and oil fired preheaters to maintain sodium temperatures during reactor refueling.

Proposed Actions System 51C: Install screens on the DHX stacks to alleviate the bird roosting problem. Inspect the $\mathrm{DHX}$ tubes to verify their condition and use the inspection results to develop a preservation plan. Visually inspect one DHX drive train per loop, and develop a drive train bearing preservation plan based on those results. Perform megger checks of the fan motors and variable speed drives, then re-energize the space heaters for the DHX fan motors and control equipment cabinets to prevent moisture condensation and related equipment degradation. Install sheet metal covers on the pre-heater supply ducts and inlet plenums to prevent corrosion due to rain water accumulation. 
HNF-SD-FF-SSP-056

Rev. 0, Page B-16

61A Closed Loop 2 Primary Coolant System

61B Closed Loop 2 Secondary Coolant System

6IC Closed Loop 2 DHX System

61D Closed Loop 2 CLIRA

61E Closed Loop 1 Primary Coolant System

61F Closed Loop 1 Secondary Coolant System

61G Closed Loop 1 DHX System

61H Closed Loop 1 CLIRA

These systems were intended to provide cooling for in-reactor experiments that were isolated from the main reactor cooling systems. Some equipment was

installed, but the systems were never completed and are currently abandoned in place. No further action will be taken during the standby period.

\section{A Sodium Receiving and Unloading System}

This system provided sodium fill capability for the primary and secondary cooling systems and is currently inactive. It is planned to be used during sodium draining. Modifications have been completed to support draining activities.

Proposed Action System 81A: Cool down the sodium drain piping that was heated specifically for secondary sodium drain.

\section{B Reactor Primary Sodium Processing}

This system provides primary sodium purification by circulating primary sodium through a cold trap and returns it to the reactor vessel to maintain vessel level. This system will remain operational.

Proposed Action System 81B: Replace obsolete electromagnetic (EM) pump controllers, which have exhibited frequent failures, with newer models.

\section{C Interim Decay Storage and Primary Sodium Storage/Processing}

This system provides IDS and stored primary sodium purification by circulating sodium through a cold trap. This system will remain operational.

\section{D NaK Interim Decay Storage Cooling System}

This system circulates NaK to remove decay heat from the IDS and transfers this heat to the Mobiltherm ${ }^{\mathrm{m}}$ System. Due to low decay heat load, NaK flow is secured (but available) and Mobiltherm ${ }^{\mathrm{TM}}$ is drained. Heat from IDS is transferred to cell ambient cooling. The system will remain operational in this configuration during the standby period.

\section{IE NaK Cold Trap Cooling System}

This system cools the primary system cold trap and transfers this heat to the Mobiltherm ${ }^{\mathrm{TM}}$ System. Due to low heat load, the Mobiltherm ${ }^{\mathrm{m}}$ System has been drained and NaK flow transfers the heat to cell ambient cooling. This system will remain operational in its present configuration during the standby period.

Proposed Action System 81E: Modify the controls to improve system operation without Mobiltherm" ${ }^{\mathrm{T}}$. 


\section{F Reactor Secondary Sodium Processing}

This system provides secondary sodium purification by circulating secondary sodium through a cold trap, one per loop. The east secondary sodium loop cold trap (N-7) was frozen in preparation for secondary loop drain. This system will remain operational during the standby period.

Proposed Action System 81F: Restore cold trap N-7 to an operational condition.

\section{Y Fuel Storage Facility Sodium Purification}

The system provides FSF sodium purification by circulating FSF sodium through a cold trap and provides auxiliary heat input, if required, to maintain bulk sodium temperature. This system will remain operational during the standby period.

\section{Fuel Storage Facility NaK Heat Transfer}

This system cools the FSF storage vessel sodium by natural circulation of two Nak loops from the vessel to two natural draft air to NaK heat exchangers. Only one of the loops was made operational. Due to low decay heat load, the one operable loop is drained to the drain tank, but available if required. The system will remain operational in this configuration during the standby period.

\section{A Argon Supply and Distribution System}

This system stores 1 iquid argon and distributes argon gas throughout the plant for reactor and secondary system cover gas, refueling machines, Interim Examination and Maintenance (IEM) Cell atmosphere, and other auxiliary liquid metal systems. This system will remain operational during the standby period.

\section{D Cel1 Atmosphere Processing System (CAPS)}

This system collects and processes the nitrogen gas from the inerted cells in the RCB and other miscellaneous process gases. It provides a vacuum for cell pressure control and can process any radionuclides in the gas using cryogenic-charcoal-delay beds. The charcoal delay beds have been warmed up and secured. The CAPS compressors have been shutdown and de-energized. A modification to add an Ex-containment CAPS B1ower was completed and is being used (in conjunction with the In-containment CAPS Blowers) in lieu of the CAPS compressors to keep the system operational. No further actions are required during the standby period.

\section{E Radioactive Argon Processing System (RAPS)}

This system collects and processes the radioactive reactor cover gas. It provides a vacuum for reactor pressure control and processes the radionuclides in the gas using cryogenic-charcoal-delay beds. The charcoal delay beds have been warmed up and secured. RAPS has been cross connected to the CAPS system. The RAPS compressors have been secured and de-energized. The system will remain operational in this condition during the standby period. 
HNF-SD-FF-SSP-056

Rev. 0, Page B-18

\section{G Nitrogen Supply and Distribution System}

This system stores liquid nitrogen and distributes liquid and gaseous nitrogen throughout the plant for in-containment inerted cells, pneumatic valve operation, RAPS and CAPS cryogenic cold-box cooling and other auxiliary systems. RAPS \& CAPS cryogenic cooling has been secured. No further actions are required during the standby period.

\section{J Vacuum System}

This system was used, in conjunction with the Argon Supply System, to reduce the oxygen content in the sodium systems to acceptable levels prior to sodium fill. Selected portable vacuum pumping units have been transferred for use in the Sodium Storage Facility. They will remain there during the standby period.

\section{L Nitrogen Atmosphere Sampling/Analys is}

This system samples the inerted cell atmospheres for oxygen and radioactivity. It has been deactivated, and will remain in this condition during the standby period.

\section{N Interim Examination \& Maintenance Cell Argon Purification System}

This system processes the argon atmosphere of the IEM Cell to remove oxygen and moisture. Due to excessive maintenance costs, it has been secured and de-energized, and argon purges are now used to control the IEM cell atmosphere. The system will remain in this condition during the standby period.

\section{Fuel Storage Facility Argon System}

This system stores liquid argon and distributes it for FSF storage vessel cover gas and NaK expansion tank cover gas. It will remain in service during the standby period.

Proposed Action System 82Z: Cross connect FSF argon to the plant argon system, then isolate and remove the FSF dewar.

\section{A Heat Transport System Primary Sodium Sampling/Monitoring}

This system provides sampling capability and continuous monitoring of primary sodium gross impurity levels. The sodium in the HTS-South sample loop is currently frozen and the associated equipment has been secured and de-energized. This part of the system will remain in this condition during the standby period. The auxiliary plugging temperature indicator located in the Containment Building remains operational.

Proposed Action System 85A: Modify/upgrade the control panel for the Primary and IDS auxiliary PTI's which, due to age, experiences frequent equipment failures.

\section{C Heat Transport System Secondary Sodium Sampling/Monitoring}

This system provides sampling capability and continuous monitoring of secondary sodium gross impurity levels. This system remains operational. 


\section{B \& 85D Closed Loop System Primary and Secondary Sodium Sampling/Monitoring}

These systems provide sampling capability for the closed loop sodium. The CLS were never completed, so these systems are currently abandoned in place.

\section{E Argon Cover Gas Sampling and Monitoring}

This system provides sampling, continuous reactor cover gas monitoring for impurities, and distribution of cover gas to the Fuel Failure Monitoring System. It has been deactivated.

Proposed Action System 85E: Repair and upgrade the refueling gas chromatograph to enable continuous monitoring capability during evolutions which increase the risk for air in-leakage.

\section{Fuel Storage Facility Sodium Sampling}

This system provides sampling capability and continuous monitoring of FSF sodium gross impurity levels. The sampling capability has been secured and de-energized, while the equipment to continuously monitor will remain operational.

\section{A Heat Transport System Flow Control System}

This system controls main sodium coolant pump speed to control the rate of sodium flow. The primary sodium pump control system has been secured and de-energized. It will be exercised during the standby period. The secondary sodium pump control system remains operational.

\section{B Heat Transport System Dump Heat Exchanger Control System}

This system controls DHX fan speed and damper position to control DHX outlet temperatures. It has been deactivated. It will remain in this condition during the standby period.

\section{C Reactor Flux Control System}

This system controls control rod position for automatic reactor power control. It has been deactivated.

Proposed Action System 90C: Temporarily enable the rod control system as required to accomplish control rod operability checks.

\section{D Reactor Plant Control Panels}

This system houses the components of the flow, DHX and flux control systems in the Control Room. A11 but secondary pump controls have been deactivated. This system will remain in this condition during the standby period.

\section{$91 \mathrm{~A}$ Plant Data System Computer, Peripherals, and CRT Displays}

This system provides continuous monitoring and recording of various plant parameters. It also performs calculations for determination of core characteristics and optimization of plant operation. It has been secured and de-energized, and will remain in this condition during the standby period. 
HNF-SD-FF-SSP-056

Rev. 0, Page B-20

\section{C Plant Data System Multiplexer}

This system is the interface between the incoming plant instrumentation and the main Plant Data System (PDS) computer. It has been secured and de-energized, and will remain in this condition during the standby period.

\section{D Experimenters Data System and Data Acquisition System}

This system provides continuous monitoring and recording of various plant parameters of importance to specific experiments. It has been deactivated and will remain in this condition during the standby period.

\section{$91 E$ EDS/CALC - Experimenters Data System Calculational Computer}

This system performs calculations using data from the Examination and Decontamination Services (EDS)/Data Acquisition System (DAS) by using programs specific to certain experiments. It has been deactivated and will remain in this condition during the standby period.

\section{Reactor and Vessel Instrumentation}

This system provides monitoring of individual core assembly and reactor vessel parameters. It has been secured and de-energized. The in-reactor sensors remain in place. This system will remain in this condition during the standby period.

\section{A Annunciator Systems - FFTF and Fuel Storage Facility}

The local control panel annunciators associated with operating equipment will remain available for operation.

\section{B Sodium Piping Trace Heat and Controls}

This system provided initial preheat of sodium systems prior to fill and continues to provide temperature control for sodium filled equipment using electric heaters and proportional controllers. It will remain operational during standby.

\section{Seismic Monitoring}

This system provides monitoring and recording of seismic activity. The system has been secured. This system will remain in this condition during the standby period.

\section{D Na Leak Detection and Alarm System}

This system provides for indication of sodium leakage using contact leak detectors and sodium aerosol detectors. The aerosol detectors are ineffective at shutdown conditions and have been de-energized. Contact leak detectors will remain operational during the standby period.

\section{Fuel Storage Facility Trace Heating and Controls}

This system provided initial preheat of sodium piping prior to fill and continues to provide temperature control for sodium filled piping using electric heaters and proportional controllers. It will remain operational. 


\section{$94 \mathrm{~A}$ Fuel Failure Monitoring System}

This system provides early detection of nuclear fuel assembly failure by continuously monitoring the reactor cover gas for fission gas and is capable of sampling the cover gas for tag gases to locate a leaking core assembly. It also monitors the primary sodium piping for neutrons emitted from fission fragments. It has been deactivated, and will remain in this condition during the standby period.

\section{A Flux Monitoring System}

This system uses neutron detectors to provide indication of reactor power and subcritical reactivity. The system has been secured and de-energized, and will remain in this condition during the standby period.

\section{A Process Radiation Monitoring}

This system provides continuous air monitoring and particulate filter monitoring for all gaseous process and exhaust paths. A portion of the system has been shutdown. The balance of the system will remain operational during the standby period.

Proposed Actions System 96A: Replace the failing electronics for the Cask Loading Station process monitor.

\section{B Area Radiation Monitoring (and 96Z, FSF Radiation Monitoring System)}

This system provides continuous monitoring and alarm capability for general plant areas. A portion of the system has been shutdown. The balance of the system will remain operational during the standby period.

\section{Information Systems}

This system supports equipment data base and work control functions. The system will remain operational during the standby period.

\section{A Reactor Shutdown System}

This system consists of the electronics that automatically scram the reactor in case of unsafe plant conditions. All nuclear fuel has been removed from the reactor. The Reactor Shutdown System has been secured and de-energized, and will remain in this condition during the standby period.

\section{B Containment Isolation System}

This system consists of the electronics that automatically seal the RCB on detection of high radiation in the containment exhaust duct. It has been secured and de-energized, and will remain in this condition during the standby period.

\section{Sodium Storage Facility (SSF)}

This facility will be placed in a standby condition. 
HNF-SD-FF-SSP-056

Rev. 0, Page B-22

\subsection{FFTF PLANT BUILDINGS}

The buildings remain in a state where all hazardous material and radiological contamination has been either removed or contained to a point that it cannot be inadvertently disturbed. Building roofs are being be maintained and upgraded to ensure roof integrity.

The following is a list of 400 Area buildings that house FFTF systems and to which these requirements apply:

BUILDING

405

$491 \mathrm{E}, \mathrm{S}, \mathrm{W}$

408 A, B, C

403

$4713 \mathrm{C}$

4717

4621E, W

483

484

4721

4703

402

\section{DESCRIPTION}

RCB - reactor vessel, HTS, IDS vessel, and refueling equipment

HTS Buildings - secondary HTS and support equipment

DHX Buildings - DHX's, sodium preheaters and support equipment

FSF - fuel storage vessel, refueling and support equipment

Contaminated Equipment Storage Building

Reactor Service Building - support equipment such as chillers, air compressors, Sodium Removal System

Auxiliary Equipment Buildings East and West electrical systems and diesel generators

Cooling Water Pad - cooling water towers and pumps

Chilled Water Building - chillers and chilled water pumps

Turbine generator and electrical switchgear

Control Building

Sodium Storage Facility - sodium storage tanks and support equipment 
TABLE B1

\section{FFTF STANDBY SYSTEM GROUPS}

\section{Group A: Systems Shutdown (Inactive Systems)}

$12 \mathrm{~J}$ Zero Time Outage - 120 Volt AC System

23S Mobiltherm ${ }^{\mathrm{TM}}$ System

23L Diesel Fuel System to Diesel Generators

$36 \mathrm{~A}$ Fusion MOTA Glove Box and Controls

25G Closed Loop H\&V system

25H RAPS and CAPS H\&V System

25L Closed Loop Gas Cooling system

25W Meteorological system

26B AFFF System

$27 \mathrm{M}$ Containment Margins

61A Closed Loop 2 Primary Coolant System

6lB Closed Loop 2 Secondary Coolant System

61C Closed Loop 2 DHX System

610 Closed Loop 2 CLIRA

$61 \mathrm{C}$ Closed Loop 1 Primary Coolant System

6lF Closed Loop 1 Secondary Coolant System

61G Closed Loop 1 DHX System

$61 \mathrm{H}$ Closed Loop 1 CLIRA

$81 \mathrm{~A}$ Sodium Receiving and Unloading System

82D CAPS (compressors and cold boxes only)

$82 E$ RAPS (compressors and cold boxes only)

82. Vacuum system

$82 \mathrm{~L} N$ Nitrogen Atmosphere Sampling/Analysis

82N IEM argon purification (R-36)

85A Primary sodium sampling (HTS-S)

85B CLS Primary Sodium Sampling/Monitoring

85D CLS Secondary Sodium Sampling System

85E Primary cover gas sampling

$85 Z$ FSF sodium sampling

90A Primary pump flow control

90B DHX fan control

90C Reactor Flux Control System

90D Reactor control panels (partial)

91A PDS Computer, Peripherals, and CRT Displays

91C PDS Multiplexer

91D EDS/DAS - Experimenters Data System/Data Acquisition System

$91 \mathrm{E}$ EDS/CALC Experimenters Data System Calculational Computer, Loose Parts Monitoring System (LPMS) Experimenters (Room 404) Computer

93C Seismic Monitoring

93D Na Leak Detection and Alarm System (aerosol detectors)

94A Fuel Failure Monitoring System

95A Flux Monitoring System

99A Plant Protection System

99B Containment Isolation System

Sodium Storage Facility 
HNF-SD-FF-SSP-056

Rev. 0, Page B-24

Group B: Systems to be Partially or Fully Restored

$12 \mathrm{H}$ Emergency Diesels (7ube oil)

25J LLFM/CRDM inert gas cooling

$31 \mathrm{~A}$ Reactor Internals (Instrument Trees)

31B Control Rod Drive Lines

4lA In-Vessel Handling Machines

51C HTS DHX system (equipment space heaters \& 1ube oi1)

90C CDRM control system (partial)

\section{Group C: Systems Remaining Operational}

$11 \mathrm{~A} \quad 115 \mathrm{KV}$ electrical

l1B $115 / 13.8 \mathrm{KV}$ transformers

$12 A \quad 125$ Volt $1 E$ DC System

12B $13.8 \mathrm{KV}$ System

$12 \mathrm{C} 2.4 \mathrm{KV}$ System (H2, H3, $\mathrm{A} 1, \mathrm{~A} 2$, and $\mathrm{A} 3$ )

$12 \mathrm{C} 2.4 \mathrm{KV}$ System - A4

$12 D 480$ Volt $A C$ normal load centers

$12 E 480$ Volt $A C$ emergency load centers

$12 \mathrm{~F}$ Lighting

12G Low volt age $A C$

$12 \mathrm{H}$ Emergency Diesel and Turbine Generators (remainder)

$12 \mathrm{~K} 480$ Volt load centers

12L Freeze protection

$12 \mathrm{M}$ Non-1E 125 VDC Battery System

$12 Z$ FSF electrical

15 A Communications

21 Support Buildings

21 Cranes

212 FSF Building

23A Well water system

23B Sanitary water system

23C Cooling Tower System

23D Cooling Water Systems

$23 \mathrm{~F}$ Ex-Containment Chilled Water System

23G In-Containment Chilled Water System

$23 \mathrm{H}$ Process and sanitary drain system

23J Instrument Air system

23M DHX fuel oil system

23P Service air system

23R Demineralized Water System

23Y FSF Auxiliary Systems

$23 Z$ FSF Chilled Water System

24A Radioactive Liquid Waste System

25A Containment H\&V System

25B. Oxygen Monitoring

25 Control Building and AEB-E H\&V System

25E RSB and AEB-W H\&V System

25F HTS and DHX Building H\&V System

25J Reactor Head Compartment/Cavity Gas Cooling System

25K IDS Vessel and Tank Cell Gas Cooling System

25M HTS Gas Cooling System

25N IEM Ce 11 and fuel Subassembly Gas Cooling System

25X FSF H\&V 


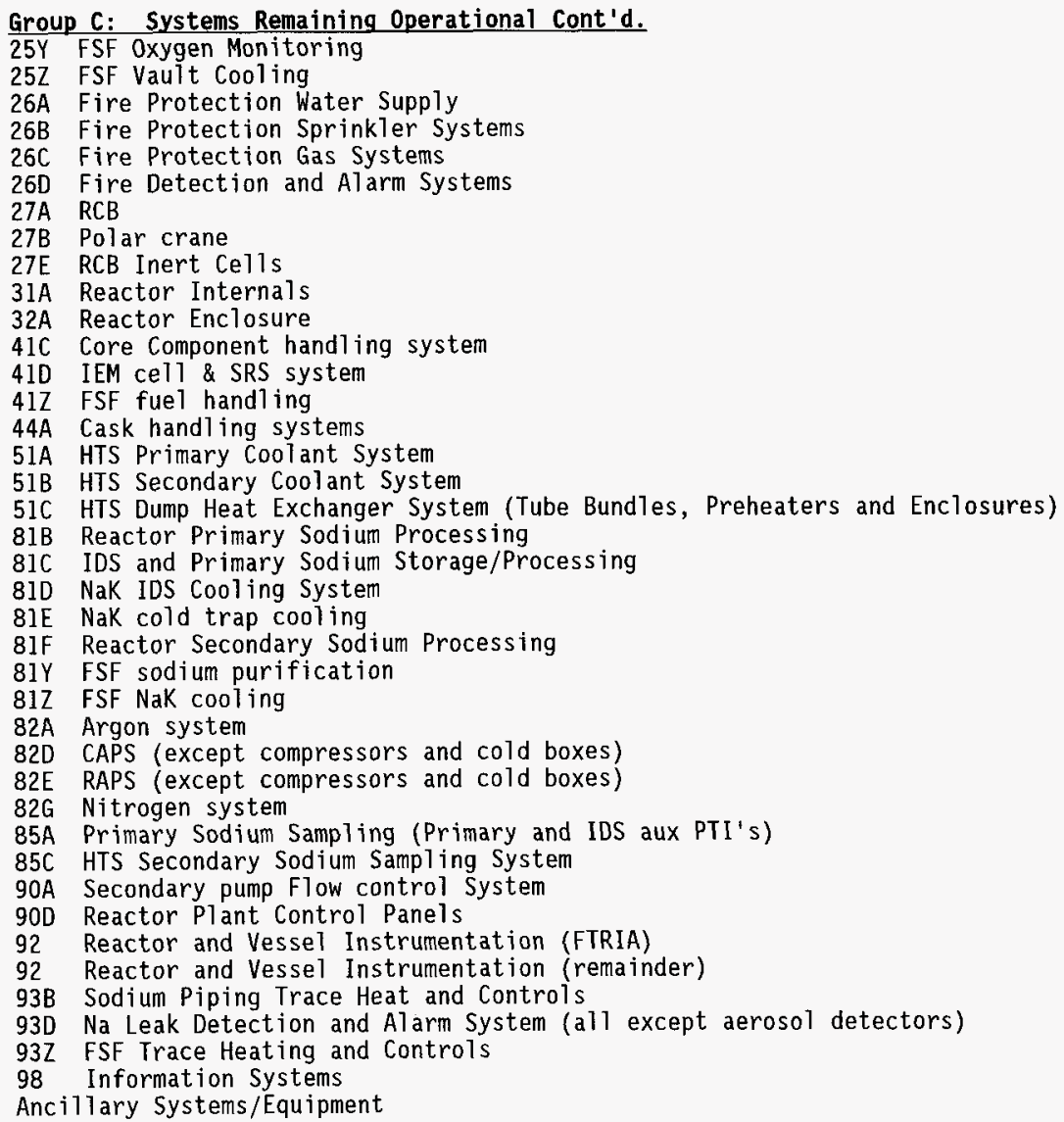


HNF-SD-FF-SSP-056

Rev. 0, Page B-26

This page intentionally left blank. 